\title{
Toward an Asian American Legal Scholarship: Critical Race Theory, Post-Structuralism, and Narrative Space
}

\author{
Robert S. Chang
}

TABLE OF CONTENTS

Prelude ................................................. 1243

Introduction: Mapping the Terrain ................... 1247

I. The Need for an Asian American Legal Scholarship ....... 1251

A. That Was Then, This Is Now: Variations on a Theme .. 1251

1. Violence Against Asian Americans ............. 1252

2. Nativistic Racism ........................ 1255

B. The Model Minority Myth .................... 1258

C. The Inadequacy of the Current Racial Paradigm....... 1265

1. Traditional Civil Rights Work ............... 1265

2. Critical Race Scholarships................... 1266

II. Narrative Space ............................... 1268

A. Perspective Matters . ........................ 1272

B. Resistance to Narrative ......................... 1273

C. Epistemological Strategies...................... 1278

1. Arguing in the Rational/Empirical Mode ......... 1279

2. Post-Structuralism and the Narrative Turn......... 1284

III. The Asian American Experience: A Narrative Account of

Exclusion and Marginalization ...................... 1286

A. Exclusion from Legal and Political Participation....... 1289

1. Immigration and Naturalization ................. 1289

2. Disfranchisement ....................... 1300

B. Speaking Our Oppression into (and out of) Existence ... 1303

1. The Japanese American Internment and Redress ... 1303

2. The Not So Model Minority ................. 1308

C. The Common Thread ......................... 1312

IV. Toward an Asian American Legal Scholarship ........... 1314

A. Stage One: Denial ........................... 1316

B. Stage Two: Affirmation ....................... 1318

C. Stage Three: Liberation ...................... 1321

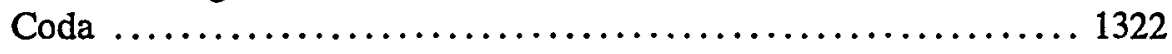




\section{Toward an Asian American Legal Scholarship: Critical Race Theory, Post-Structuralism, and Narrative Space}

\section{Robert S. Chang†}

As Asian Americans join the legal academy in growing numbers, they change the face of the academy and challenge its traditional legal doctrines. The author announces an "Asian American Moment" in the legal academy and an opportunity to reverse the pattern of discrimination against Asian Americans. Traditional civil rights work and current critical race scholarship fail to address the unique issues for Asian Americans, including nativistic racism and the model minority myth. Space must be made in the legal academy for an Asian American Legal Scholarship and the narratives of Asian Americans. The author states that the rational-empirical mode is inadequate as a justification for narrative scholarship and argues for a post-structural basis for Asian American Legal Scholarship. He gives a few historical examples of how narrative can be used to effect social change. Finally, the author offers a framework for constructing an Asian American Legal Scholarship which acknowledges the tremendous diversity among the disempowered but which also recognizes that it is through solidarity that Asian Americans will gain the freedom to express their diversity.

\section{Prelude}

I am a second generation Korean American without any achievements in life and I have no education. What is it you want to hear from me? My life is not worth telling to anyone.

You know, it seems to me there's no use in me telling you all this! I was just a simple worker, a farmworker around here. My story is

$\dagger \quad$ Visiting Assistant Professor, Golden Gate University School of Law. A.B. 1988, Princeton University; M.A., J.D. 1992, Duke University. Copyright (C) 1993 by California Law Review, Inc. and Asian Law Journal.

I am indebted to Todd Hughes and Jasmin Patel for their moral support and invaluable comments during the writing of this Article. My gratitude also extends to the University of Puget Sound School of Law for its support which permitted me to present a version of this Article at the 1993 Midwest Asian American Students Union Spring Conference at Ohio State University. I would also like to thank the editors of Asian Law Journal and the California Law Review, with special thanks to Karin Wang of Asian Law Journal and to Eugene Pak and Cathy Ostiller of the California Law Review. 
not going to interest anybody. ${ }^{1}$

Of the different voices in which I speak, I have been most comfortable with the one called silence. Silence allowed me to escape notice when I was a child. I could become invisible, and hence safe.

Yet now I find myself leaving the safety of my silence. I wonder if this is wise. I teach legal writmg; I want to teach substantive law. ${ }^{2}$ I have been told that engaging in nontraditional legal scholarship may hurt my job prospects, that I should write a piece on intellectual property, where my training as a molecular biologist will lend me credibility.

I try to follow this advice, but my mind wanders. I think about the American border guard who stopped me when I tried to return to the United States after a brief visit to Canada. My vahid Ohio driver's license was not good enough to let nie return to my country. He asked nie where my passport was. I told him that I did not have one and that it was my understanding that I did not need one, that a driver's license was sufficient. He told me that a driver's license is not proof of citizenship. We were at an impasse. I asked him what was going to happen. He said that he might have to detain me. I looked away. I imagined the phone call that I would have to make, the embarrassment I would feel as I told my law firm in Seattle that I would not be at work the next day, or maybe even the day after that-until I could prove that I belonged. I thought about my naturalization papers which were with niy parents in Ohio. I thought about how proud I had been when I had become a citizen.

Before then, $I$ had been an alien. Being a citizen meant that $I$ belonged, that $I$ had the same rights as every other American. At least, that is what I used to believe. Things have happened since then that have changed my mind. Like the time I was driving in the South and was refused service at a service station. Or the tinie I was stopped in New Jersey for suspicion of possessing a stolen vehicle. At first, it was just two cops. Then another squad car came. Four big (white) policemen for one small (Asian) nian, in a deserted parking lot-no witnesses if it came to that. Perhaps they were afraid that I night know niartial arts, which I do, but I am careful never to let then know. When niy license and registration checked out, they handed back my papers and left without a word. They could not even say that one word, "Sorry," which would have allowed me to leave that incident behind. I night have forgotten it as a mistake, one of those unpleasant things that liappen. Instead, I have to carry it with nie because of the anger I feel, and because of the fear-

1. Ronald Takaki, Strangers from a Different Shore: A History of Asian AMERICANS 9 (1989) (using Asian American "voices" to provide an overview of Asian American history).

2. I was teaching legal writing when I wrote this Article; I now teach contracts. I have, to an extent, gotten my wish. 
fear of the power that certain people are able to exercise over me because of this (contingent) feature that makes me different. No matter how hard I scrub, it does not come clean. No matter how hard I try, and I do try, I can never be as good as everyone else. I can never be white.

These are the thoughts that intrude when I think about intellectual property. I try to push them away; I try to silence them. But I am tired of silence.

And so, I raise my voice.

Professor Jerome Culp raised his voice when he proclaimed boldly to the legal academy that it was in "an African-American Moment," a time "when different and blacker voices will speak new words and remake old legal doctrines." 3 He also cautioned that "[t]hose in the legal academy who cannot speak the language of understanding will be relegated to the status of historical lepers alongside of Tory Americans and Old South Democrats." 4 It remains to be seen whether his prophecy will come true. The mainstream legal academy has largely ignored his proclamation and the work of other critical race scholars, if frequency of citation is to be taken as a measure of attention, ${ }^{5}$ and some legal scholars have condemned the methods of critical race scholarship. ${ }^{6}$

Nevertheless, the time has come to announce another such moment, an Asian American Moment. ${ }^{7}$ This Moment is marked by the increasing

3. Jerome M. Culp, Jr., Toward a Black Legal Scholarship: Race and Original Understandings, 1991 Duxe L.J. 39, 40. I take my title from his article, which I see not only as a challenge to African American legal scholars but also as a challenge to all scholars of color.

4. Id. at 41 .

5. See Richard Delgado, The Imperial Scholar: Reflections on a Review of Civil Rights Literature, 132 U. PA. L. REV. 561 (1984) (discussing how the mainstream legal academy often ignores work by feminists and critical race scholars); Richard Delgado, The Imperial Scholar Revisited: How to Marginalize Outsider Writing, Ten Years Later, 140 U. PA. L. REv. 1349 (1992) (same); Randall L. Kennedy, Racial Critiques of Legal Academia, 102 HARV. L. REv. 1745, 1771-72 (1989) (critiquing Delgado's first Imperial Scholar piece).

6. One surprising example of this criticism is found in a recent article by a well-known figure of the legal left, Mark Tushnet. In The Degradation of Constitutional Discourse, 81 GEo. L.J. 251, 251 (1992), he discusses the works of, among others, Patricia Williams and Derrick Bell, and concludes that many of their stories are ultimately flawed by "failures of integrity and judgment." For a cogent response to Tushnet's article, see Gary Peller, The Discourse of Constitutional Degradation, 81 GEO. L.J. 313 (1992) (critiquing Tushnet's analysis and defending the works of the critical race scholars). I find it troubling, though, that this exchange takes place between two white law professors, one attacking critical race theory and one coming to its rescue. In some ways, this dialogue is an example of the paternalism that often exists when an issue involving race or work by scholars of color is evaluated. See Derrick A. Bell, Jr., Bakke, Minority Admissions, and the Usual Price of Racial Remedies, 67 CALIF. L. REv. 3, 4 (1979) (comparing the efforts of whites to exclude minorities from meaningful participation in the Bakke litigation and the surrounding debate to the attitude of traditional parents who tell their protesting children, "Keep quiet. We are talking about you, not to you.").

7. Given the relative scarcity of Asian American law professors, it might seem premature or overly optimistic to make such a claim. These moments, however, may last "mere seconds or whole decades." Culp, supra note 3, at 41 . My hope is that this Moment will not be short-lived.

Before I proceed further, I should define certain terms. There is tremendous diversity within 
presence of Asian Americans in the legal academy who are beginning to raise their voices to "speak new words and remake old legal doctrines." This Moment brings new responsibilities for Asian American legal scholars. ${ }^{9}$ This Moment brings new challenges. This Moment also brings us hope. ${ }^{10}$

the category "Asian American," in which I include persons of Asian descent who live in the United States regardless of citizenship status. I hesitate to define "Asian American" further because this term is malleable and is often used by the dominant group to confer and deny benefits. For example, Asian Indians are sometimes denied benefits given to other Asian American groups because they are considered Caucasian. At other times, they are categorized as Asian Americans. See TAkAk1, supro note 1, at 295-97 (discussing how early Asian Indians were considered the "new 'Yellow Peril" " and were targeted by the Asiatic Exclusion League, even though Asian Indians were generally recognized as Caucasians).

Geographic terms, such as "Far East," "Southeast Asia," "Indian subcontinent," and "Pacific Islanders," are often used in defining Asian Americans. See U.S. CoMM'N ON CiviL RIGHTS, CiviL Rights Issues Facing Asian AmERiCans iN THE 1990s, at 1 n.4 (1992) [hereinafter CiviL RIGHTS REPORT]. However, the terms "Far East" and "Indian subcontinent," like the term "Oriental," are colonialist terms, and to accept them is to acquiesce to colonialist authority. Cf. Homi K. Bhabha, Signs Taken for Wonders: Questions of Ambivalence and Authority Under a Tree Outside Delhi, May 1817, in "RACE," Writing, AND Difference 163, 172 (Henry L. Gates, Jr. ed., 1986) ("[E]xercise of colonialist authority . . . requires the production of differentiations, individuations, identity effects through which discriminatory practices can map out subject populations that are tarred with the visible and transparent mark of power."). I note, though, that even the term "Asian American," "[l]ike its predecessor, 'Oriental,' . . . was created in the West from the need to make racial categorizations in a racially divided or, at least, a racially diverse society." Elaine H. Kim, Asian AmERICAN Literature: AN INTRODUction to the Writings aNd Their Social CONTEXT xii (1982).

Regardless of its origins, however, "Asian American" can serve as a unifying identity based on the common experiences of Asian Americans because of the inability of most non-Asian Americans to distinguish between different Asian groups. Unfortunately, this inability to distinguish between Asians has not translated into an inability to discriminate against Asians, as evidenced by the tragic death of Vincent Chin. Chin, a Chinese American, was killed by two white autoworkers who called him a "Jap" and blamed him for the loss of jobs in the American auto industry. CiviL Rights REPORT, supra at 25-26; see infra notes 32-43 and accompanying text.

I use "Asian American" rather than "Asian Pacific American" or "Asian/Pacific Islander," not in an exclusionary manner, but because I find the other terms cumbersome. This may seem unsatisfactory or capricious on my part, but it is nevertheless the reason behind my choice. Despite the different labels, I define the three terms in the same fashion.

8. Culp, supra note 3, at 40 . Evidence of this increasing presence is found in the rising enrollment of Asian Americans in law schools and the sparse but growing population of Asian American law professors. It is also cvident in two new law journals, Asian Law Journal and the UCLA Asian American Pacific Islands Law Joumal, which published its first issue in Spring 1993.

9. As is the case with Black legal scholars, see Culp, supra note 3 , at $45-48$, the proper role for Asian American legal scholars is difficult to define.

10. I should comment here about my use of pronouns. Minority scholars face a difficult choice when they write about minority issues and the law. Kimberle Williams Crenshaw writes about this problem in the context of African American scholarship:

One of the conventions of dominant scholarship is the use of "they" or "them" to denote Blacks as a subject group. Implicit in such references is a silent "we" which carries the appearance of objectivity but actually presumes a dominant group perspective. This creates a dilemma for some Black scholars who must either risk self-exclusion by referring to our own cultural group as "they" or adopt a seemingly unscholarly approach to the subject by assuming a "we" identity. 


\section{INTRODUCTION: MAPPING THE TERRAIN}

Asian Americans suffer from discrimination, ${ }^{11}$ much of which is quantitatively and qualitatively different from that suffered by other disempowered groups. ${ }^{12}$ The qualitative difference, in that Asian Americans suffer as Asian Americans and not just generically as persons of color, has certain implications for the study of Asian Americans and the law. ${ }^{13}$ One implication is that traditional civil rights work, with its focus on color bhindness or denial of substantial difference, even when

Kimberlé W. Crenshaw, Race, Reform, and Retrenchment: Transformation and Legitimation in Antidiscrimination Law, 101 HARV. L. REv. 1331, 1332 n.2 (1988).

When I refer to Asian Americans, I use the first person plural pronouns "us" or "we" rather than "them" or "they." I also use "us" or "we" when referring more generally to the disempowered. To do otherwise would be to place an unnatural and uncomfortable distance between myself and my subject. On the other hand, I use "them" and "they" generally to refer to the dominant group. I realize that this may set up an unhelpful us/them dichotomy, but using "we" when referring to Asian Americans is more honest in that it is an important part of the perspective from which I write. Also, by consciously reversing the traditional alignment-us/dominant group and them/minority group-I hope to highlight the problems with the traditional usage: if my "we" identity seems unscholarly, their "we" identity is equally problematic. I return to this point when 1 talk about the "constitutive we." See infra notes 182-84 and accompanying text. My point about pronouns may seem reminiscent of the debate over the use of gendered pronouns.

11. This claim seems uncontroversial to me, but in the spring of 1991, a national poll conducted by the Wall Street Journal and NBC News "revealed that the majority of American voters believe that Asian Americans are not discriminated against in the United States" and that "[s]ome even believe that Asian Americans receive too many special advantages." "CIVIL RIGHTS REPORT, supra note 7, at 1 (quoting Michel McQueen, Voters' Responses to Poll Disclose Huge Chasm Between Social Attitudes of Blacks and Whites, WALI ST. J., May 17, 1991, at A16) (footnote omitted). The Civil Rights Report calls this a misconception and goes on to compile evidence confirming that Asian Americans do face widespread prejudice, discrimination, and barriers to equal opportunity. Asian Americans are frequently victims of racially motivated bigotry and violence; they face significant barriers to equal opportunity in education and employment; and they do not have equal access to a number of public services, including police protection, health care, and the court system.

Id. at 1 . The "model minority" myth plays an important role in creating and perpetuating this misconception. See infra Part I.B.

12. See infra Part I.

13. I realize that this may raise the (obligatory) essentialist question. I do not make the claim that there is a unitary, essential Asian American experience. Such a claim would be foolhardy given the diversity encompassed in the category "Asian American" and in its intersection with gender, class, sexual orientation, and disability. However, acknowledging the limitations behind the category "Asian American" does not render the term "Asian American" meaningless. For example, "Asian American" can be used as a "strategic identity." See Angela P. Harris, Race and Essentialism in Feminist Legal Theory, 42 STAN. L. REV. 581, 610-12 (1990) (explaining how the recognition of the relational nature of difference and identity can be advantageous to feminist theory); see also BILl ONg HiNG, Making and Remaking Asian America Through IMMIGRATION POLICY 1850-1990, at 169 (1993) ("Asian American was a political label chosen by the people themselves in the 1960's."). Or being Asian American can be used as part of one's "multiple consciousness." See Mari J. Matsuda, When the First Quail Calls: Multiple Consciousness as Jurisprudential Method, Address Before the Yale Law School Conference on Women of Color and the Law (Apr. 16, 1988), in 11 WoMEN's RTS. L. REP. 7, 9 (1989) (urging female lawyers to recognize the different life experiences of other women). Even though the category "Asian American" can (and perhaps should) be subverted, one can still "tak[e] advantage of a civil rights heritage that is grounded on identity politics." Nan D. Hunter, Life After Hardwick, 27 HARV. C.R.-C.L. L. REV. 531, 546-47 (1992) (describing the tension for gay and lesbian rights advocates 
done in the context of securing rights for Asian Americans, is inadequate to address fully the needs of Asian Americans. ${ }^{14}$ Another implication is that critical race theory, ${ }^{15}$ which claims that race matters but which has not yet shown how different races matter differently, is also inadequate to address fully the needs of Asian Americans. ${ }^{16}$ To help complete the pic-

between civil rights claims that use identity politics and the "desire to deconstruct the imprisoning category itself"').

14. See infra Part I.C.1.

15. Richard Delgado describes critical race scholarship as having the following themes:

(1) an insistence on "naming our own reality"; (2) the belief that knowledge and ideas are powerful; (3) a readiness to question basic premises of moderate/incremental civil rights law; (4) the borrowing of insights from social science on race and racism; (5) critical examination of the myths and stories powerful groups use to justify racial subordination; (6) a more contextualized treatment of doctrine; (7) criticism of liberal legalisms; and (8) an interest in structural determinism-the ways in which legal tools and thoughtstructures can impede law reform.

Richard Delgado, When a Story Is Just a Story: Does Voice Really Matter?, 76 VA. L. REV. 95,95 n.1 (1990). John Calmore includes race in his characterization:

So, then, critical race theory can be identified as such not because a random sample of people of color are voicing a position, but rather because certain people of color have deliberately chosen race-conscious orientations and objectives to resolve confiicts of interpretation in acting on the commitment to social justice and antisubordination.

John O. Calmore, Critical Race Theory, Archie Shepp, and Fire Music: Securing an Authentic Intellectual Life in a Multicultural World, 65 S. CAL. L. REV. 2129, 2163 (1992); see also Robin D. Barnes, Race Consciousness: The Thematic Content of Racial Distinctiveness in Critical Race Scholarship, 103 HARV. L. REV. 1864 (1990) (discussing the importance of racial consciousness to critical race theory).

I realize that this may raise the question of whether a white person can engage in critical race scholarship. My intuition, which is in part determined by my belief in nonessentialism, is that sensitive whites could do critical race theory, but it would be very difficult because much of critical race theory comes from an experience-based perspective. See Jerome M. Culp, Jr., Voice, Perspective, Truth, and Justice: Race and the Mountain in the Legal Academy, 38 LoY. L. REv. 61, 73 (1992) ("[T]here is no essentialist aspect to racial scholarship[,] but . . . our own imperfect methods of learning and hearing will make the possibility of whites becoming a part of the movement against racial oppression difficult but not impossible. If one reads the scholarship of the people involved in the creation of this new scholarship of color, it is obvious that there is no sign in front of the scholarship that says 'whites need not apply." ") (footnote omitted); cf. Calmore, supra at 2171 ("Critical race theory tends, in response, toward very personal expression that allows our experiences and lessons, learned as people of color, to convey the knowledge that we possess in a way that is empowering to us and, it is hoped, ultimately empowering to those on whose behalf we act.").

A similar question has been debated in the context of feminism. See generally MEN IN FEMINISM vii-viii (Alice Jardine \& Paul Smith eds., 1987). The essays in this collection tend to agree with the opening statement of the lead essay: "Men's relation to feminism is an impossible one." Stephen Heath, Male Feminism, in MEN IN FEMINISM, supra at 1, 1. But see Joseph A. Boone, Of $M e(n)$ and Feminism: Who(se) is the Sex that Writes?, in GENDER AND Theory: Dialogues on FEMINIST CRITICISM 158 (Linda Kauffman ed., 1989) [hereinafter GENDER AND TheORY] (criticizing the impossibility thesis of MEN IN FEMINISM). Boone's essay also appears in ENGENDERING MEN 11 (Joseph A. Boone \& Michael Cadden eds., 1990). Essays in this latter collection, written largely by gay men, argue that men can engage in feminist theory. Returning to my intuition, I believe that whites can engage in critical race theory if they have the requisite level of empathy, an empathy that may find its source in some other type of oppression that they suffer.

16. This comment is meant as a challenge, not as a criticism; critical race scholars recognize the need to explore this area more fully. See Calmore, supra note 15, at 2173-78 (discussing Professor Randall Kennedy's critique of Mari Matsuda). This article represents a step in that direction. See infra Part I.C.2. 
ture, there must be an Asian American Legal Scholarship. ${ }^{17}$ This Asian American Legal Scholarship will provide a framework that will encompass and mediate between the notions of hiberalism underlying Asian American civil rights work and the critical perspectives contained within critical race theory.

I sketch the outlines of this scholarship with several goals in mind. An Asian American Legal Scholarship will recognize that Asian Americans are differently situated historically with respect to other disempowered groups. But it will also acknowledge that, in spite of these historical differences, the coinunonality found in shared oppression can bring different disempowered groups together to participate in each others' struggles. ${ }^{18}$ An Asian American Legal Scholarship will argue that the exclusion of Asian Americans from the political and legal processes has led to an impoverished notion of politics and law that fur-

17. Even though I take the term "Asian American Legal Scholarship" from Professor Culp's "Black Legal Scholarship," our terms do not correspond exactly. I am uncomfortable with the way Professor Culp distinguishes Black Legal Scholarship from what he calls "Black Jurisprudence." He uses "jurisprudence" to mean "a description of the course of court decisions" and "legal scholarship" to mean "the science or philosophy of law." Culp, supra note 3, at 49. This seems backwards to me, but in order to provide some sort of consistency, I define legal scholarship as he does: the science or philosophy of law. I replace "jurisprudence," though, with "civil rights work," a term used by Todd Hughes. See Todd M. Hughes, "We are Outlaws in the Law": Lesbians, Gay Men and Bisexuals, and the New Gay Legal Scholarship (1993) (unpublished manuscript, on file with author). Hughes defines "traditional gay civil rights work" as "the set of practices that confronts and challenges the various doctrinal issues in the law that work both to subjugate gay men and lesbians and to discriminate against our rights as equal citizens in the law." Id. at 12. "Civil rights work," as related to Asian Ameriean Legal Scholarship, probably does not encompass all that Culp envisions in "jurisprudence," but it provides a useful vocabulary for this Article.

In making this distinction between traditional civil rights work, which seeks to minimize differences, and Asian American Legal Scholarship with its claim of distinctiveness, it might seem that I am setting up what Anthony Appiah calls "the classic dialectic of reaction to prejudice":

The thesis in this dialectic . . . is the denial of difference. Du Bois' antithesis is the acceptance of difference, along with a claim that each group has its part to play; that the white race and its racial Other are related not as superior to inferior but as complementaries; that the Negro message is, with the white one, part of the message of humankind.

I call this pattern the classic dialectic for a simple reason: we find it in feminism also- on the one hand, a simple claim to equality, a denial of substantial difference; on the other, a claim to a special message, revaluing the feminine Other not as the helpmeet of sexism, but as the New Woman.

Anthony Appiah, The Uncompleted Argument: Du Bois and the Illusion of Race, in "RACE," Writing, AND DifFerencE, supra note 7, at 21, 25. However, Asian American Legal Scholarship, in making its claim of distinctiveness, is not simply the antithesis to Asian American civil rights work.

18. A study of race relations in the United States cannot focus solely on the relationship between the dominant white majority and each subordinate minority group. It must also focus on interethnic and interracial relations. This expansion of the study of "Majority-Minority Relations" to include "Minority-Minority Relations" represents a necessary shift in the current paradigm of racial dynamics in the United States. See Shirley Hune, An Overview of Asian Pacific American Futures: Shifting Paradigms, in The State of Asian Pacific America[,] A Public Policy Report: Policy Issues to THE YeAr 2020, at 1, 5-6 (LEAP Asian Pac. Am. Pub. Policy Inst. and UCLA Asian Am. Studies Ctr. eds., 1993) [hereinafter THE STATE of Asian Pacific AMERICA]. 
thers the oppression of Asian Americans. It will offer the inclusion of Asian American voices in the form of narrative, personal and otherwise, ${ }^{19}$ in the practice of legal scholarship as a powerful method to combat the effects of exclusion. Finally, by including narratives in law review articles, briefs, and law teaching, this legal scholarship will inore effectively persuade decision-inakers, practitioners, law professors, and students.

My primary objective in outlining these goals is to correct what I perceive as a problem in the current discourse on race and the law. This discourse is circumscribed insofar as certain perspectives have been excluded froin the conversation. ${ }^{20}$ A natural solution to this problem is to include the narratives of the excluded. Therefore, I address two corollary questions: why narrative should count and how narrative counts. I also lay out a theoretical framework to support further work in Asian American Legal Scholarship. ${ }^{21}$

Before examining the role of narrative in legal scholarship, I explore in Part I the need for an Asian American Legal Scholarship. I discuss some of the ways in which Asian American history and the Asian American experience are unique and different from the history and experiences of other diseinpowered groups. I also briefly discuss how traditional civil rights work and critical race scholarship have not adequately addressed these differences. In Part II, I give a brief, semi-historical account of the use of personal narrative in academic discourse, and $I$ discuss epistemology, because our epistemological stance or theory of knowledge will determine what role narrative can and should play. Part III provides a narrative account of the exclusion and marginalization of Asian Ainericans from the legal and political spheres. I also show how narrative has been used effectively to address some of the problems facing Asian Americans. Finally, in Part IV, I sketch a framework for Asian American Legal Scholarship and its goal of redressing oppression. ${ }^{22}$

19. Narrative would include not just the personal narrative of the author, but also actual and fictional narratives of others told by the author. See, e.g., DerRICk BELl, AND WE ARE NOT SAVED: The EluSIVE QUEST FOR RAClAL JUSTICE (1987) (using fictional narratives to discuss racc and the law); Mari J. Matsuda, Public Response to Racist Speech: Considering the Victim's Story, 87 MICH. L. REV. 2320 (1989) (using narratives of victims to challenge the absolutism of traditional First Amendment jurisprudence).

20. See infra Part I.C.

21. See infra Part IV.

22. I posit redressing oppression as a goal because a general aversion to oppression exists in our society. I note that I am not making a foundational claim here in order to circumvent any criticism that I have fallen into the modernist trap. See Mark Tushnet, Reply, 81 GEo. L.J. 343, 343 n.1 (1992) (quoting Stephen Feldman, Send in the Clowns: Postmodernism, Legal Scholarship, and the Teague Rule Against New Rules in Habeas Corpus Cases 59 (unpublished manuscript, on file with the Georgetown Law Journal) (describing "the postmodern police, scanning the scholarly production of other postmodernists for the inevitable traces of modernism.")). 
The NeEd for an ASIAN AMERICAN Legal ScholarShiP

Present-day attitudes often demonstrate a lack of understanding about the history and current status of Asian Americans. Because a comprehensive overview of Asian American history is beyond the scope of this article, ${ }^{23} \mathrm{I}$ will discuss two major issues here: nativistic violence and discrimination against Asian Americans, and the "model minority" myth. In Part III, I will return to these and other issues and events which have profoundly shaped Asian American history and our current status. While all disempowered groups have suffered from exclusion and marginalization, Asian Americans have been subjected to unique forms of exclusion and oppression. Traditional civil rights advocates and critical race scholars have failed to account sufficiently for these differences. ${ }^{24}$ An Asian American Legal Scholarship is needed to change the current racial paradigm which is madequate to support a more complete discourse on race and the law.

\section{A. That Was Then, This Is Now: Variations on a Theme}

Many people remain unaware of the violence and discrimination that have plagued Asian Americans since their arrival in this country. ${ }^{25}$ Moreover, those who know the history often fail to make the connection between the history and the ongoing problems that continue to plague Asian Americans today. ${ }^{26}$ The philosopher George Santayana said that "[p]rogress, far from consisting in change, depends on retentiveness. ... Those who cannot remember the past are condemned to repeat it." 27 When I look at certain recent events, such as the rise in the incidence of hate crimes directed toward Asian Americans, ${ }^{28}$ or the rhetoric of the

23. For general works discussing Asian American history, see Sucheng ChaN, AsIAN AMERICANS: AN INTERPRETIVE HISTORY (1991); TAKAKI, supra note 1; see also infra Part III (discussing Asian American narratives).

24. See infra Part I.C.

25. Much of this ignorance can be attributed to United States history textbooks which fail to include Asian Americans in the history of this nation. See RACISM AND SEXISM RESOURCE CTR. FOR EDUCATORS, COUNCIL ON INTERRACIAL BOOKS For CHILdREN, STEREOTYPES, Distortions AND OMISSIONS IN U.S. History TEXTBOoks 33-54 (1977) (demonstrating, through examples and commentary, distortions and omissions in history textbooks, with checklists to help evaluate other textbooks for fair coverage).

26. I attribute this lack of awareness in part to school history textbooks which "routinely omit the word 'because.' ... Students must guess whether facts strung together are causally related. Texts present a 'crabgrass' or 'natural disaster' theory of history; problems unaccountably grow until they become serious, at which time they keep on going until they stop." Stephen E. Gottlieb, In the Name of Patriotism: The Constitutionality of "Bending" History in Public Secondary Schools, 62 N.Y.U. L. REV. 497, 510-11 (1987).

27. 1 George Santayana, The Life of Reason 284 ( $2 d$ ed. 1922).

28. See infra text accompanying notes 32-46. 
official English movement ${ }^{29}$ and of politicians such as Patrick Buchanan, ${ }^{30}$ or even the uproar caused by the sale of the Rockefeller Center and the Seattle Mariners to Japanese investors, ${ }^{31}$ I question how much progress we have made. I wonder if Saltayana is right, because when I look at those events, I see a replay of the past, variations on the tired theme of anti-Asian sentiment.

\section{Violence Against Asian Americans}

Anti-Asian sentiment has historically expressed itself in violent attacks against Asian Americans. The killing of Vincent Chin in Detroit is one variation on this theine. Vincent Chin was the Chinese American killed in 1982 by Detroit autoworkers Ronald Ebens and Michael Nitz. Ebens, according to one witness, said "that it was because of people like Chin-Ebens apparently mistook him for a Japanese-that he and his fellow employees were losing their jobs."32 The two inen pleaded guilty to manslaughter and were each given three years' probation and fines of $\$ 3,780 .^{33}$ They did not serve a single day in jail for the killing of Vincent Chin. ${ }^{34}$

When criticized for the light sentence, Judge Kaufinan defended himself in a letter to a newspaper:

He said that in Michigan, sentences are tailored to the criminal and not just to the crime. According to him, since Ebens and Nitz had no previous criminal record, were longtime residents of the area, and were respectably einployed citizens, he thought there was no reason to suspect they would harm anybody again. Hence, the light sentences. ${ }^{35}$

29. The official English movement seeks to have English declared the official language of the United States. See infra note 59.

30. See infra note 60 .

31. See infra notes 63-64 and accompanying text.

32. ChaN, supra note 23, at 177 . The men did not discriminate in their use of epithets; they also called him a "Chink." American Citizens for Justice, Confidential Report on the Vincent Chin Case to the U.S. Dep't of Justice, Civil Rights Division, 3 (June 28, 1983) (copy on file with author).

33. Civil RIGHTS REPORT, supra note 7, at 25. The light sentences and the acceptance of the pleas are curious given that during the preliminary examination, Judge Thomas $\mathrm{C}$. Bayles "opined at length on the record that the killers had been "undercharged" " because they had been charged only with murder in the second degree. American Citizens for Justice, supra note 32, at 5. Judge Bayles was apparently reacting to the fact that after an initial altercation inside a bar, Ebens took a baseball bat out of his car and together with Nitz began chasing Chin, who managed to escape. Ebens and Nitz then enlisted the aid of a friend and searched the streets for 20 to 30 minutes before finally finding Chin and ambushing him from behind. Nitz held him while Ebens hit Chin with the baseball bat. Two off-duty police officers "observed numerous double-handed swings to Vincent's body, and then four fatal blows to his head." Id. at 3-4.

34. ChAN, supra note 23, at 178; CiviL Righrs REPORT, supra note 7, at 26.

35. CHAN, supra note 23, at 177. Professor Chan notes that "[a] number of newspaper editorials pointed out that, in essence, the message Judge Kaufman was imparting to the public was that in the state of Michigan, as long as one was employed or was going to school, a license to kill cost only $\$ 3,000 . "$ Id. 
Following efforts by several California congressmen and a Detroitbased commumity organization, ${ }^{36}$ the United States Justice Department brought federal civil rights charges against the two men. ${ }^{37}$ During the initial federal civil rights trial, Ebens was found guilty and sentenced to twenty-five years; Nitz was acquitted. ${ }^{38}$ Ebens' conviction was overturned on appeal. ${ }^{39}$ When his case was retried, it was moved to Cincinnati upon a notion for change of venue. ${ }^{40}$ Ebens was ultinately acquitted. ${ }^{41}$ The change in venue may have played an iniportant role in this acquittal. ${ }^{42}$ Cincinnati residents and jurors had little exposure to Asian Americans; they were also unfamiliar with the level of anti-Asian sentiment then rampant in Detroit. ${ }^{43}$

I relate this story not to point out a iniscarriage of justice-others have done so more eloquently than I ever could. ${ }^{44}$ And I nnderstand that our judicial systen is not perfect. Instead, I tell the story to begin developing the thesis that the killing of Vincent Chin is not an isolated episode. Violence stems fron, and is causally related to, anti-Asian feelings that arise during times of econonnic hardship and the resurgence of nativisn. ${ }^{45}$

Another variation on the theme of anti-Asian sentiment is the killing of Navroze Mody. Mody was an Asian Indian who was beaten to

36. Id. The community group American Citizens for Justice was organized two weeks after the light sentences were handed down. They submitted a report to the Civil Rights Division of the U.S. Department of Justice. See American Citizens for Justice, supra note 32 (setting forth the factual and legal bases supporting prosecution of Ebens and Nitz for federal civil rights violations).

37. CIVIL RIGHTS REPORT, supra note 7, at 25 .

38. Id.

39. United States v. Ebens, 800 F.2d 1422 (6th Cir. 1986); see also Civil. Rights ReporT, supra note 7, at 25-26 (discussing reversal).

40. United States v. Ebens, 654 F. Supp. 144 (E.D. Mich. 1987); see also CiviL. RighTs REPORT, supra note 7, at 26 (discussing motion).

41. Civil Rights Report, supra note 7, at 25-26.

42. Others argue that the blame lies with the federal civil rights laws. See id. at 26 (suggesting possible jury confusion over what was needed to find Ebens guilty under 18 U.S.C. $\$ 245(b)(2)$ (1988)).

43. See Chan, supra note 23, at 178; Civil Rights ReporT, supra note 7, at 26 ("Whereas Detroit in the early 1980s was the scene of a massive media campaign against foreign imports, especially those from Japan, a campaign that inflamed anti-Asian sentiments in that city, there had not been the same type of campaign in Cincinnati.").

44. See, e.g., Chan, supra note 23, at 176-78 (noting details, such as that Lily Chin, Vincent's mother, "was so upset by the final outcome that she left the United States ... to live in China").

45. Nativism is the

intense opposition to an internal minority on the grounds of its foreign (i.e., "unAmerican") connections. Specific nativistic antagonisms may, and do, vary widely in response to the changing character of minority irritants and the shifting conditions of the day; but through each separate hostility runs the conneeting, energizing force of modern nationalism. While drawing on much broader cultural antipathies and ethnocentric judgments, nativism translates them into a zeal to destroy the enemies of a distinctively American way of life.

Juan F. Perea, Demography and Distrust: An Essay on American Languages, Cultural Pluralism, and Official English, 77 MiNN. L. REv. 269, 278 (1992) (quoting JOHN HighaM, STRANGERS IN THE LAND 4 (2d ed. 1988)). 
death in 1987 in Jersey City by a gang of eleven youths. The gang did not harm Mody's white friend. No inurder or bias charges were brought; three of the assailants were convicted of assault while one was convicted of aggravated assault. ${ }^{46}$

To understand the significance of this attack, it inust be placed in context. Asian Indians were the fastest-growing immigrant group in New Jersey; many settled in Jersey City. ${ }^{47}$ Racially motivated hostilities mcreased with the growth of the Asian Indian cominunity and the transformation of Jersey City as Asian Indians opened shops and restaurants. ${ }^{48}$ Earlier in the month that Navroze Mody was killed, a Jersey City gang called the Dotbusters had published a letter in the Jersey Journal saymg that they "would 'go to any extreme' to drive Indians froin Jersey City." 49 Violence against Asian Indians began the next day, leading up to and continuing after the killing of Mody. ${ }^{\text {so }}$ One community leader said that "the violence worked. . . . People moved out, and others thinking of inoving here froin the city inoved elsewhere."s1

These recent events read in some ways like a page from the book of history. They resemble other racially inotivated incidents of the past, such as what happened in 1877 in Chico, California. While attenipting to burn down all of Chico's Chinatown, white arsonists murdered four Chinese by tying them up, dousing thein with kerosene, and setting them on fire. ${ }^{52}$ The arsonists were inembers of a labor union associated with the Order of Caucasians, a white supremacist organization which was active throughout California. The Order of Caucasians blamed the Chinese for the economic woes suffered by all workers. ${ }^{53}$

The Chinese Massacre of 1885 also took place in the context of a

46. CIVIL RIGHTS REPORT, supra note 7, at 29.

47. Al Kamen, When Hostility Follows Immigration: Racial Violence Sows Fear in New Jersey's Indian Community, WASH. POST, Nov. 16, 1992, at A1, A6.

48. Id.

49. Id. at A6. The Dotbusters named themselves after the bindi, the dot that Indian women often wear as a sign of marital fidelity. Id.

50. CIVIL RIGHTS RePORT, supra note 7, at 28-29; see also Kamen, supra note 47, at A6 (discussing, among other incidents, the beating of an Asian Indian in his home after his name had been picked out of a phone book, one day after the Dotbusters' letter was printed).

51. Kamen, supra note 47 , at A6.

52. CHAN, supra note 23 , at 49 . They were convicted but were released long before the end of their sentences. Id.

53. Id.; Sucheng Chan, This Bitrersweet Soll: The Chinese in California Agriculture, 1860-1910, at 370 (1986). The Order of Caucasians was also known as the Caucasian League. Their tactics included warning letters such as the following to people who employed Chinese laborers:

Dear Sir: You are respectfully requested without further warning to discharge the Chinamen in your employ, and give your work to whites instead, whom you well know are suffering from the effects of all those heathens in our midst. Think well of the country of your adoption, and try to assist the poor white man in making an honest living. Take heed lest the course you are now pursuing shall fall upon your own liead with tenfold vengeance. [Signed]-Native Americans.

Id. at 370-71. 
struggling economy and a growing nativist inovement. In Rock Springs, Wyoming, a mob of white miners, angered by the Chmese miners' refusal to join their strike, killed twenty-eight Chinese laborers, wounded fifteen, and chased several hundred out of town. A grand jury failed to indict a single person. ${ }^{54}$

I could go on, ${ }^{55}$ but my point is not merely to describe. I seek to link the present with the past. In linking these late-nineteenth century events with present events, I inay seem to be drawing improper associations by taking events out of context. In fact, I ain doing the reverse: placing present events imto context to show that today's rising incidence of hate crimes against Asian Americans, like the violence of the past, is fostered by a chinate of anti-Asian sentiment spurred by economic troubles and nativism. As Professor Stanley Fish said in a different context, "I am argumg for a match at every level, froin the smallest detail to the deepest assumptions. It is not simply that the books written today bear soine similarities to the books that warned earlier generations of the ethnic menace: they are the same books."56 Fish was discussing books, but there is, of course, a sometimes unfortunate link between words and deeds.

\section{Nativistic Racism}

The words accoinpanymg the violent deeds of the present also grow out of the resurgence of nativisin. ${ }^{57}$ This resurgence is apparent in some (1940).

54. Paul Crane \& Alfred Larson, The Chinese Massacre, 12 AnNals of Wyoming 47, 47-49

55. My informal count, based on a very limited survey of the literature, came up with over 300 Chinese killed in racially motivated assaults in the West between 1860 and 1887. See ANTIChinese Violence in North AMerica (Roger Daniels ed., 1978) (anthology of eleven articles discussing various incidents); CHAN, supra note 23, at 48-51; ROGER DANIELS, ASIAN AMERICA: CHINESE AND JAPANESE IN THE UNITED STATES SiNCE 1850, at 58-64 (1988). I hesitate to provide even that number because much of the violence was not documented; we will never know the actual number. See id. at 58-59. I provide the number, though, because I am shocked by it. I am even more shocked to think that this number is an underestimate. Call it naivete or what you will, but the widespread violence against Chinese immigrants was not in the United States history textbooks of my youth. Nor is it acknowledged by many scholars. Id. at $59 \mathrm{n.66}$ (citing Richard M. Brown, Historiography of Violence in the American West, in HisTORIANS AND THE AMERICAN WEST 234, 250-51 (Michael P. Malone ed., 1983), and noting that Brown limits his discussion of anti-Chinese violence to two paragraphs). This lack of coverage is odd because even though the Western Frontier was a violent place, "with the exception of the American Indians, no group there suffered as much from violence as did the Chinese." Id. at 58.

While Chinese immigrants suffered from the most violence, other Asian immigrant groups that followed them were by no means immune. See, e.g., CHAN, supra note 23, at 51-53 (discussing some of the violence against Asian Indians, Japanese, Koreans, and Filipinos).

56. Stanley Fish, Bad Company, 56 Transition 60, 63 (1992) (criticizing ARTHuR SCHLESINGER, JR, THE DISUNITING OF AMERICA: REFlections ON A MULTICULTURAL SOCIETY (1991), and arguing that modern works, such as Schlesinger's book, repeat the arguments made in works by overtly racist authors from the late-nineteenth and early-twentieth centuries).

57. See Lynne Henderson, Authoritarianism and the Rule of Law, 66 IND. L.J. 379, 380 (1991) 
of the arguments marshalled against multiculturalism ${ }^{58}$ and in the official Enghish movement. ${ }^{59}$ Some pohticians have used the rhetoric of nativism to great effect, gaining support among segments of the population. ${ }^{60}$

Nativism, with its message of America first, has a certain allure. Indeed, to reject its message seems unpatriotic. However, present-clay nativism is grounded in racism, ${ }^{61}$ and thus, is inconsistent with American

(noting "the resurgence of active manifestations of racism, anti-semitism and nativism") (footnotes omitted).

58. Professor Fish provides a cogent summary of Arthur Schlesinger's antimulticulturalist arguments:

[Schlesinger] finds the threat in what he calls the "ethnic upsurge," an "unprecedented ... protest against the Anglocentric culture" that "today threatens to become a counterrevolution against the original theory of America as . . . a common culture, a single nation." Schlesinger deplores the rejection of what he calls "the old American idcal of assimilation"- the ideal that asks immigrants and minorities to "shed their ethnicity" in favor of the Western Anglo-Saxon tradition. ... "White guilt," he declares, "can be pushed too far," and he predicts that the multiculturalist ethnic upsurge will be defeated by the fact that "the American synthesis has an inevitable Anglo-Saxon coloration."

It is clear from these quotations that for Schlesinger the danger of multiculturalism is not confined to the classroom, but extends to the very fabric of our society.

Fish, supra note 56 , at $60-61$ (some alteration in original).

59. The official English movement secks to have English declared the official language of the United States. See generally Antonio J. Califa, Declaring English the Official Language: Prejudice Spoken Here, 24 HARv. C.R.-C.L. L. REv. 293 (1989) (providing the historical context of the official English movement and arguing that the proposed federal law would not survive equal protection scrutiny); Perea, supra note 45, at 340-50 (discussing the strategy and goals of the official English movement).

Antonio Califa refers to the official English movement as "the English-Only inovement." Califa, supra at 293. They are not the same, nor are they mutually exclusive. However, the declaration of English as the official language paves the way for English-Only measures by providing the basis for discriminatory English-Only rules in the workplace and challenges to bilingual services. See id. at 300-03 (discussing the effects of California's Proposition 63, which makes English the official state language). Discriminatory English-Only rules and loss of bilingual services will have a heavy impact on Asian Americans, $65 \%$ of whom are foreign born. See Kathryn K. Imahara, Language Rights Issues to the Year 2020 and Beyond: Language Rights Policy, in THE STATE OP Asian PACIFIC AMERICA, supra note 18, at 233, 237-48 (discussing the Asian American community's need for bilingual services).

At the federal level, efforts to establish English as the official language by constitutional aniendment or by federal statute have thus far failed. See Perea, supra note 45 , at 341 . The official English movement has had much more success at the state level. As of 1992, seventeen states had enacted statutes or constitutional aniendments making English their official language. Id. at 342 \& n.407. In most of these states, the measures have passed with overwhelming margins. Id. at 342 .

60. One obvious politician is Patrick Buchanan with his "take back America" message. See E.J. Dionne, Jr., Buchanan's Political Street Fight: Challenger's Conservatism Rooted in Catholic Upbringing, WASH. POST, Feb. 15, 1992, at A1, A20 (noting that Buchanan was quoted in a June 1990 article as asking, "Who speaks for the Euro-Americans who founded the United States? . . Is it not time to take America back?").

61. Many commentators discuss racism and nativism together as part of a list. See, e.g., Henderson, supra note 57, at 380 (noting the recent "resurgence of active manifestations of racism, anti-semitism and nativism") (footnote omitted); David A. Martin, Due Process and Membership in the National Community: Political Asylum and Beyond, 44 U. PITT. L. REV. 165, 204 (1983) (describing patriotism as "the vehicle for racist or nativist policies"). Asian Americans suffer from both racism and nativism. See, e.g., Hiroshi Motomura, Immigration Law After a Century of Plenary Power: Phantom Constitutional Norms and Statutory Interpretation, 100 YALE L.J. 545, 550 (1990) (discussing "racist and nativist anti-Chinese sentiment" in California in the late-nineteenth 
values. In this way, it differs from the nativism that first swept this country in the 1840s; that nativism included anti-Catholic and anti-European strains. ${ }^{62}$ Present-day nativism also differs from the traditional paradigm of racism by adding an element of "foreign."

Nativistic racism lurks behind the spectre of "the Japanese "taking over," which appeared when Mitsubishi Corporation bought a $51 \%$ share of the Rockefeller Center ${ }^{63}$ and when Nintendo purchased "a piece of America's national pastime." of "the Japanese taking over" is that "the Japanese" did not buy Rockefeller Center; nor did "Japan" buy a piece of America's national pastime. ${ }^{65}$ In both instances, private corporations made the investments. The second problem is that there is "an outcry when the Japanese buy American institutions such as Rockefeller Center and Columbia Pictures, but not when Westerners do."66 Moreover, the notion of the Japanese "taking over" is factually unsupported. As of January 1992, in the midst of the clamor about the Japanese buying out America, Japanese investors owned less than $2 \%$ of United States commercial property. ${ }^{67}$

Similarly, in 1910, three years before California passed its first Alien Land Laws (prohibiting aliens ineligible for citizenship from owning real property), Japanese Americans, aliens and citizens, controlled just $2.1 \%$ of Cahifornia's farms. ${ }^{68}$ Nevertheless, the Japanese Americans were per-

century). Rather than think of the terms as co-equal, Professor Kenneth Karst explores the intersection of racism and nativism, commenting that the belief "that full membership in America would be extended to all who would embrace the nation's ideals . . . was so easily twisted into racist nativism." KeNNETH L. KARST, BELONGING To AMERICA: EQUAL Citizenship AND THE CONSTITUTION 84 (1989). However, in my view, the order of the terms should be reversed to correctly reflect priority; "nativistic racism" is a more apt description.

62. DANIELS, supra note 55, at 31-32.

63. See Steve Garbarino, Fear in a Climate of Japan Bashing, NEwSDAY, Feb. 6, 1992, at 67 (quoting Fumi Matsuda, a Japanese-American college student).

64. Mark Potts, Japan and Mariners: Quandary for Game, WASH. PosT, Feb. 28, 1992, at Fl, F6. Nintendo sought to buy the Seattle Mariners baseball team. In a later story, Potts notes that "[a] majority of Americans have said in surveys that they disapproved of Japanese ownership in the national pastime." Mark Potts, Japanese Cleared for Seattle Baseball Deal, WASH. PosT, June 10, 1992, at A1, A18.

65. See Jonathan Rauch, Just Another Ordinary Different Place: $A$ Meditation on the Soul of Japan, and the Myths that Hide it from Both Americans and the Japanese, L.A. TIMES, Mar. 8, 1992, Magazine, at 10,12 (discussing the tendency of newspapers to speak of Japan "as a person," as in this example: "'Japan' is beating American companies and buying Rockefeller Center").

66. Ronald E. Yates, Ishihara's Essays on Japan-U.S. Ties Still Hit the Mark, CHI. TrIB., Apr. 19, 1992, at C3 (quoting Shintaro Ishihara, The JaPAN THat CAN SAY No: Why JAPAN WiLl BE First Among EQUals (1991)).

67. See Don't Reject Japanese Pitch, USA TodAY, Jan. 29, 1992, at 10A. This editorial also points out that, in other countries, United States businesses own "everything from England's Jaguar to corners near Russia's Red Square." Id. British investors actually own much more of the United States than do Japanese investors. See Mike Meyers, Enduring U.S.-Japanese Rivalry Has Roots That Precede World War II, STAR TRIB., Dec. 8, 1991, at 1A.

68. Edwin E. Ferguson, The California Alien Land Law and the Fourteenth Amendment, 35 CALIF. L. REV. 61, 77 (1947).

I refer to both Japanese-bom aliens and their American-born offspring as Japanese Americans. 
ceived to be a threat of such magnitude that a law was passed "to discourage further immigration of Japanese aliens to California and to call to the attention of Congress and the rest of the country the desire of California that the 'Japanese menace' be crushed."69 The law was tailored to meet this aim by limiting its ambit to aliens ineligible for citizenship. ${ }^{70}$ In this way, European interests were protected. ${ }^{71}$

The climate of anti-Asian sentiment, still present today, hurts Asian Americans because, as the death of Vincent Chin has demonstrated, many non-Asian Americans persist in thinking of Asian Americans as foreign. ${ }^{72}$ It is this sense of "foreignness" that distinguishes the particular type of racism aimed at Asian Americans.

\section{B. The Model Minority Myth}

This history of discrimination and violence, as well as the contemporary probleins of Asian Americans, are obscured by the portrayal of Asian Americans as a "model minority." Asian Americans are portrayed as "hardworking, intelligent, and successful."73 This description represents a sharp break from past stereotypes of Asians as "sneaky, obsequious, or inscrutable."74

But, the dominant culture's ${ }^{75}$ belief in the "model minority" allows

I do not differentiate because the naturalization statutes prevented Japanese-born aliens from becoming United States citizens. See Ozawa v. United States, 260 U.S. 178 (1922) (finding that Japanese immigrants are not within purview of the naturalization statutes); see also infra Part III.A.1.

69. Ferguson, supra note 68, at 62. The focus of anti-Asian feelings shifted from the Chinese to the Japanese because "the Chinese problem" had already been taken care of by various federal and state measures. See infra Part III.A.1.

For a discussion of alien land laws in other states, see Dudley O. McGovney, The Anti-Japanese Land Laws of California and Ten Other States, 35 CALIF. L. REv. 7 (1947).

70. The naturalization statute in effect in 1913 restricted naturalization to free white persons and persons of African nativity or descent. The United States Supreme Court had not yet decided the issue of naturalization for Asian immigrants, but these immigrants were apparently excluded from this statute.

71. See Ferguson, supra note 68, at 66-67 (discussing strong pressure brought by various chambers of commerce, boards of trade, merchants associations, and foreign oil and copper syndicates for a law with limited applicability instead of one affecting all aliens).

72. See DANIELS, supra note 55, at 343 (quoting Professor Floyd Shinomura: "The Vincent Chin case reminds us that non-Asian Americans tend to see all Asians as foreigners.").

73. Civil. RightS REPORT, supra note 7, at 19.

74. Id.

75. When I speak about methods being used by the dominant culture, I do not intend to endorse a conspiracy theory. Instead, I subscribe to what Professor Charles Lawrence describes as "strain theory," which can be contrasted to "interest theory":

According to one theory, domination occurs when the ruling class gains the consent of the dominated classes through a system of ideas that reinforces the morality or inevitability of the existing order. This "interest theory" sees ideology as a consciously wielded weapon, an intellectual tool that a group uses to enhance its political power by institutionalizing a particular view of reality.

Another view of ideology draws upon ... theories of unconscious motivation . . . . Under this view, ideology is a defense mechanism against the anxiety felt by those who hold power through means and with motives that they cannot comfortably acknowledge. 
it to justify ignoring the unique discrimination faced by Asian Americans. The portrayal of Asian Americans as successful permits the general public, government officials, and the judiciary to ignore or marginalize the contemporary needs of Asian Americans.

An early articulation of the model minority theme ${ }^{76}$ appeared in U.S. News \& World Report in 1966:

At a time when Americans are awasl in worry over the plight of racial minorities-

One such minority, the nation's 300,000 Chinese-Americans, is winning wealtl and respect by dint of its own hard work.

In any Chinatown from San Francisco to New York, you discover youngsters at grips with their studies. ...

Still bemg taught in Chinatown is the old idea that people should depend on their own efforts-not a welfare check-in order to reach America's "prormsed land."

Visit "Chinatown U.S.A." and you find an important racial mimority pulling itself up from hardship and discrimmation to become a model of self-respect and achievement in today's America. ${ }^{77}$

This "model minority" theme has become a largely unquestioned assumption about current social reality. ${ }^{78}$

This "strain theory" explains ideology as a response to the strains that an individual's or a group's social role or position creates. ... [I]t enables privileged individuals to continue practices they would otherwise condemn and in which their own complicity would be painful to admit.

Charles R. Lawrence, III, The Id, the Ego, and Equal Protection: Reckoning with Unconscious Racism, 39 STAN. L. REV. 317, 326 (1987) (footnotes omitted).

76. Perhaps the first person to use the term "model minority" was Professor William Petersen, a demographer-sociologist at the University of California, Berkeley. See DANIELs, supra note 55, at 317 (citing William Petersen, Success Story, Japanese American Style, N.Y. TIMES, Jan. 6, 1966,

Magazine, at 20). Professor Daniels comments that Petersen

developed the phrase "model minority," using the term "model" in two senses: first, as a way of praising the superior performance of Japanese Americans; and second, as a way of suggesting that other ethnic groups should emulate the Japanese American example. The unstated major premise of Petersen's argument was that Horatio-Alger-bootstrap-raising was needed for success by such "non-achieving" minorities as blacks and Chicanos, rather than the social programs of Lyndon Johnson's "Great Society."

Id. at 318 .

77. Success Story of One Minority Group in U.S., U.S. NEWS \& WORLD REP., Dec. 26, 1966, at 73, 73, reprinted in Roots: AN ASIAN AMERICAN READER 6 (Amy Tachiki et al. eds., 1971) (emphasis added).

78. The current majority perception that Asian Americans do not suffer from discrimination, see supra note 11 , was created in part by media stories in the mid-1980s, an especially fruitful period for the perpetuation of the model minority myth:

In 1986, NBC Nightly News and the McNeil/Lehrer Report aired special news segments on Asian Americans and their success, and a year later, CBS's 60 Minutes presented a glowing report on their stunning achievements in the academy. "Why are Asian Americans doing so exceptionally well in school?" Mike Wallace asked, and quickly added, "They must be doing something right. Let's bottle it." Mcanwhile, U.S. News \& World Report featured Asian-American advances in a cover story, and Time devoted an entire section on this meteoric minority in its special immigrants issue, "The Changing Face of America." Not 
At its surface, the label "model minority" seems like a compliment. However, once one moves beyond this complimentary façade, one can see the label for what it is-a tool of oppression which works a dual harm by (1) denymg the existence of present-day discrimination against Asian Americans and the present-day effects of past discrimination, and (2) legitimizing the oppression of other racial minorities and poor whites.

That Asian Americans are a "model minority" is a myth. But the myth has gained a substantial following, both imside and outside the Asian American commumity. ${ }^{79}$ The successful mculcation of the model minority myth has created an audience unsympathetic to the problems of Asian Americans. Thus, when we try to make our problems known, our complaints of discrimination or calls for remedial action are seen as unwarranted and mappropriate. They can even spark resentment. For example, Professor Mitsuye Yamada tells a story about the reactions of her Ethnic American Literature class to an anthology compiled by some outspoken Asian American writers:

[One student] blurted out that she was offended by its militant tone and that as a white person she was tired of always being blamed for the oppression of all the minorities. I noticed several of her classmates' eyes nodding in tacit agreement. A discussion of the "militant" voices in some of the other writings we had read in the course ensued. Surely, I pointed out, some of these other writings have been just as, if not 1nore, militant as the words in this introduction? Had they been offended by those also but failed to express their feelings about them? To my surprise, they said they were not offended by any of the Black American, Chicano or Native American writings, but were hard-pressed to explain why when I asked for an explanation. A little further discussion revealed that they "understood" the anger expressed by the Blacks and Chicanos and they "empathized" with the frustrations

to be outdone by its competitors, Newsweek titled the cover story of its college-campus magazine "Asian-Americans: The Drive to Excel" and a lead article of its weekly edition "Asian Americans: A 'Model Minority.' " Fortune went even further, applauding them as "America's Super Minority," and the New Republic extolled "The Triumph of Asian Americans" as "America's greatest success story."

TAKAKI, supra note 1, at 474.

79. Perhaps the most prominent Asian American proponent of the model minority myth was former Senator S.I. Hayakawa, who, according to one poet,

Tells the blacks

and browns

and yellows to

"use the magic

bootstraps.

Work hard, smile alot, keep your place..."

Todd Lee, Hayakawa Blues, 7-8 SUNBURY 76 (1979) (alteration in original). 
and sorrow expressed by the Native American. But the Asian Americans?? [sic]

Then finally, one student said it for all of them: "It made me angry. Their anger made me angry, because I didn't even know the Asian Americans felt oppressed. I didn't expect their anger." 80

This story illustrates the danger of the model minority myth: it renders the oppression of Asian Americans invisible. This invisibility has harmful consequences, especially when those in positions of power cannot see:

To be out of sight is also to be without social services. Thinking Asian Americans have succeeded, government officials have sometimes denied funding for social service programs designed to help Asian Americans learn Enghish and find enployment. Failing to realize that there are poor Asian families, college administrators have sometimes excluded Asian-American students from Educational Opportunity Programs (EOP), which are intended for all students from low-income families. ${ }^{81}$

In this way, the model minority myth diverts much-needed attention from the problems of many segments of the Asian American community, particularly the Laotians, Hmong, Cambodians, and Vietnamese who have poverty rates of $67.2 \%, 65.5 \%, 46.9 \%$, and $33.5 \%$, respectively. ${ }^{82}$ These poverty rates compare with a national poverty rate of $9.6 \% .^{83}$

In addition to government officials, this distorted view of the current status of Asian Americans has infected at least one very influential member of the judiciary and legal academy. At a recent conference of the Association of American Law Schools, Judge Posner asked two rhetorical questions: "Are Asians an oppressed group in the United States today? Are they worse off for lacking sizable representation on the faculties of American law schools?" 84 His questions are rhetorical because he already has answers, with figures to back them up: "In 1980, JapaneseAmericans had inconies more than $32 \%$ above the national average income, and Chinese-Americans had incomes more than $12 \%$ above the national average; Anglo-Saxons and Irish exceeded the average by $5 \%$

80. Mitsuye Yamada, Invisibility is an Unnatural Disaster: Reflections of an Asian American Woman, in THIS BRIDGe Called My BaCK: Writings By Radical Women of Color 35, 35 (Cherrie Moraga \& Gloria Anzaldúa eds., 1981) [hereinafter ThIs BRIDGe CALled MY BACK].

81. TAKAKI, supra note 1, at 478; see also CIVIL RIGHTS REPORT, supra note 7, at 20 (quoting U.S. COMM'N ON CIVIL RIGHTS, SUCCESS OF ASIAN AMERICANS: FACT OR FICTION? 24 (1980)) ("Despite the problems Asian Americans encounter, the success stereotype appears to have led policy makers to ignore those truly in need.").

82. Civil Rights RePORT, supra note 7, at 17.

83. Id. Only two groups of Asian Americans, Filipino Americans and Japanese Americans, have poverty rates below the national average at $6.2 \%$ and $4.2 \%$, respectively. Id.

84. Richard A. Posner, Duncan Kennedy on Affirmative Action, 1990 DUKE L.J. 1157, 1157 (revised text of speech delivered on January 4, 1991, at Association of American Law Schools convention). 
and $2 \%$, respectively." 85 He also points out that "in $1980,17.8 \%$ of the white population aged 25 and over had completed four or more years of college, compared to $32.9 \%$ of the Asian-American population."86

The unspoken thesis in Judge Posner's cominents, which has been stated by other proponents of meritocracy, is "that, when compared to Whites, there are equal payoffs for qualified and educated racial ininorities; education and other social factors, but not race, determine earnings."87 If Posner is right, Asian Americans should make as much as their white counterparts, taking into account "education and other social factors, but not race." Yet when we look more carefully at the statistics, we find some interesting anounalies which belie the meritocratic thesis.

First, Posner's rehance on inedian family income ${ }^{88}$ as evidence for lack of discriminatory effects in employment is misleading. It does not take into account the fact that Asian American families have more workers per household than do white families;" in fact, "more Asian American woinen are compelled to work because the male members of their families earn such low wages."90 Second, the use of national income averages is nisleading because most Asian Americans live in geographical locations which have both higher incomes and higher costs of living. ${ }^{91}$ Wage disparities become apparent when geographic location is considered. ${ }^{92}$ Third, the fact that Asian Americans have a ligher percentage of college graduates does not mean that they have econoinic opportunities coininensurate to their level of education. Returns on education rather than educational level provide a better indicator of the existence of discrimination. ${ }^{93}$ Many Asian Ainericans have discovered tliat they, like other racial minorities, do not get the same return for their

85. Id. at 1157 n.2.

86. Id.

87. Henry Der, Asian Pacific Islanders and the "Glass Ceiling"-New Era of Civil Rights Activism?: Affirmative Action Policy, in The STATE OF ASIAN PACIFIC AMERICA, supra note 18, at 215, 219 (discussing and discrediting the meritocratic thesis).

88. Posner does not indicate that he is using median family incomes, even though this is what Sowell, the source upon which Posner relies, reported. See supra note 85.

89. See CHAN, supra note 23, at 168 (noting that, in 1970, 60\% of Japanese and Chinese American families were composed of more than one worker as compared to $51 \%$ of all families in the United States); CIVIL RIGHTS REPORT, supra note 7, at 18; TAKAKI, supra note 1, at 475 ("In 1980, white nuclear families in California had only 1.6 workers per family, compared to 2.1 for Japanese, 2.0 for immigrant Chinese, 2.2 for immigrant Filipino, and 1.8 for immigrant Korean (this last figure is actually higher, for many Korean women are unpaid family workers).").

90. CHAN, supra note 23, at 169.

91. See TAKAKI, supra note 1, at 475 (noting that " 59 percent of all Asian Americans lived in [California, Hawaii, and New York, three high-income, high-cost-of-living states] in 1980, compared to only 19 percent of the general population"). Professor Chan also comments on the concentration of Asian Americans in high-income and high-cost-of-living cities, including Honolulu, San Francisco, Los Angeles, Chicago, and New York. CHAN, supra note 23, at 168.

92. See infra note 96.

93. See CHAN, supra note 23 , at 169. 


\section{educational investment as do their white counterparts. ${ }^{94}$}

A closer look, then, at Japanese Americans, Posner's strongest case, reveals flaws in his meritocratic thesis when mdividual income, geographic location, educational attainment, and hours worked are considered. In 1980, Japanese American men im California earned incomes comparable to those of white men, but "they did so only by acquiring more education (17.7 years compared to 16.8 years for white men twenty-five to forty-four years old) and by working more hours $(2,160$ hours compared to 2,120 hours for white men in the same age category)."95 The income disparities for men ${ }^{96}$ from other Asian American groups are inore glaring. ${ }^{97}$

Thus, the answer to Posner's first question ${ }^{98}$ is yes-Asian Americans are an oppressed group in America. To accept the myth of

94. One study reported that "for each additional year of education, whites earned $\$ 522$ more, compared to $\$ 438$ for Japanese, $\$ 320$ for Chinese, $\$ 340$ for Mexican Americans, and $\$ 284$ for blacks." Id. at 168 (citing Robert M. Jiobu's 1976 study of American-born men in California).

95. TAKAKI, supra note 1 , at 475 .

96. I use figures for men because calculations become more complex when both race and gender are considered. Complexity is, of course, not a good reason for avoiding this important issue, but I will defer the discussion to another time because the complexity is buttressed by contradictory figures on women's income. Compare Der, supra note 87, at 220 ("[C]ontrolling for educational and occupational status when compared to white women, Asian Pacific Islander women do as well if not slightly better, in terms of earned median income.") with CHAN, supra note 23, at 169 ("But despite their high educational level, [Asian American women] receive lower returns to their education than do white women.") and Deborah Woo, The Gap Between Striving and Achieving: The Case of Asian American Women, in Making Waves: AN ANThology of Writings By AND About Asian AMERICAN WOMEN 185, 192 (Asian Women United of Cal. ed., 1989) ("While education enhances earnings capability, the return on education for Asian American women is not as great as that for other women."). Professors Chan and Woo note two factors that Henry Der may not have considered, that Asian American women live in localities with higher wages and that a larger percentage of Asian American women work full-time than do their white counterparts. CHAN, supra note 23, at 169; Woo, supra at 187-88. Also, the higher median income does not take into account the unpaid labor of many Asian American women in small, family-owned businesses, many of which operate with very low gross earnings. See CHAN, supra note 23, at 169-70.

Even though Asian American women may have higher median incomes, one must not forget the large concentration of Asian American women employed in modern "sweatshops." See, e.g., Dennis Hayashi, Preventing Human Rights Abuses in the U.S. Garment Industry: A Proposed Amendment to the Fair Labor Standards Act, 17 YALE J. INT'L L. 195 (1992) (describing garment industry "sweatshops" and calling for a change in the Fair Labor Standards Act to hold clothing manufacturers liable for the wage and hour violations of their subcontractors); Miriam C. Louie, Immigrant Asian Women in Bay Area Garment Sweatshops: "After Sewing, Laundry, Cleaning and Cooking, I Have No Breath Left to Sing," 18 AMERASIA J. 1 (1992) (discussing the special problems faced by immigrant women in the garment industry, including poor working conditions, lack of benefits, and sub-minimum wages).

97. Professor Takaki reports that in California,

Korcan men earned only $\$ 19,200$, or 82 percent of the income of white men, Chinese men only $\$ 15,900$ or 68 percent, and Filipino men only $\$ 14,500$ or 62 percent. In New York the mean personal income for white men was $\$ 21,600$, compared to only $\$ 18,900$ or 88 percent for Korean men, $\$ 16,500$ or 76 percent for Filipino men, and only $\$ 11,200$ or 52 percent for Chinese men.

TAKAKI, supra note 1 , at 475 .

98. I return to his second question, whether Asian Americans are disadvantaged by their lack of representation on law school faculties, in Part I.C. 
the model minority is to participate in the oppression of Asian Americans.

In addition to hurting Asian Americans, the model minority myth works a dual harm by hurting other racial minorities and poor whites who are blamed for not being successful like Asian Americans. "African-Americans and Latinos and poor whites are told, "look at those Asians-anyone can make it in this country if they really try." "99 This blame is justified by the meritocratic thesis supposedly proven by the example of Asian Americans. ${ }^{100}$ This blaine is then used to campaign against government social services for these "undeserving" minorities and poor whites ${ }^{101}$ and against affirmative action. ${ }^{102}$ To the extent that Asian Americans accept the inodel ininority myth, we are complicitous in the oppression of other racial ininorities and poor whites.

This blame and its consequences create resentment against Asian Americans among African Americans, Latinos, and poor whites. ${ }^{103}$ This resentment, fueled by poor economic conditions, can flare into anger and violence. Asian Americans, the "model minority," serve as convenient scapegoats, as Korean Americans in Los Angeles discovered during the 1992 riots. ${ }^{104}$ Many Korean Americans "now view theinselves as "human shields' in a coinphicated racial hierarchy," caught between "the racism of the white majority and the anger of the black minority." 105 The inodel minority myth plays a key role in establishing a racial hierarchy which demes the oppression of Asian Americans while simultane-

99. Mari Matsuda, We Will Not Be Used, Address Before the Asian Law Caucus Annual Fundraising Dinner (Apr. 1990), in 1 UCLA AsIAN AM. PAC. IsLANDS L.J. 79, 80 (1993).

100. See supra notes 84-87 and accompanying text.

101. See TAKAKI, supra note 1 , at 478.

102. See id. (discussing Asian American exclusion from Educational Opportunity Programs). There is considerable controversy about elite colleges' and universities' admissions policies that discriminate against Asian Americans. Neoconservatives have shifted the focus of this controversy to affirmative action programs in general. See Dana Y. Takagi, From Discrimination to Affirmative Action: Facts in the Asian American Admissions Controversy, 37 Soc. ProBs. 578, 578.79 (1990) (discussing how neoconservatives successfully shifted the focus of the discourse from discrimination against Asian Americans to an attack on affirmative action in general). They were successful despite the efforts of Asian American groups to denounce the neoconservative arguments. Id.; $f$. Grace W. Tsuang, Note, Assuring Equal Access of Asian Americans to Highly Selective Universities, 98 YALE L.J. 659, 659 (1989) ("An Asian applicant would not challenge the legality of preferential admissions nor allege that a Black or Hispanic had gained entrance in place of a better qualified Asian. Instead, the basis of the claim ... would focus on the treatment of Asian Americans compared with Caucasians, a group never intended to be the beneficiaries of affirmative action.").

103. TAKAKI, supra note 1 , at 478.

104. Almost half of the looting and violence in the 1992 riots was directed at Korean American businesses. See Seth Mydans, Giving Voice to the Hurt and Betrayal of Korean-Americans, N.Y. TIMES, May 2, 1993, $\S 4$, at 9 (interviewing Angela Oh, Korean Anjerican attorney and president of the Southern California Korean American Bar Association).

105. Id.; see also Matsuda, supra note 99 , at 79 (discussing the notion of a racial hierarchy and suggesting that Asian Americans could become "the racial bourgeoisie," the race-oriented version of Marx's middle-class "economic bourgeoisie"). 
ously legitimizing the oppression of other racial minorities and poor whites.

\section{The Inadequacy of the Current Racial Paradigm}

Most discussions of race and the law focus on African Americans to the exclusion of non-African American racial minorities. ${ }^{106}$ To limit the discussion in this way is a mistake. Analogies nay be drawn between the discrimination experienced by different disempowered groups, but care inust be taken to avoid confusing one form of discrimination with another. ${ }^{107}$ The dominant group has used various inethods of discrimination, legal and extralegal, against different disempowered groups. ${ }^{108}$ The differences between these groups inust be considered in a discourse on race and the law if we are to use law as a means to help end racial oppression. Both traditional civil rights work and critical race theory have failed to account sufficiently for these differences.

\section{Traditional Civil Rights Work}

Traditional civil rights work presents two problems for Asian Americans. The first is a matter of coverage; the second, a matter of theory. By coverage, I mean that civil rights advocates sometimes forget to consider Asian Americans when they are battling discrimination. For example, when civil rights advocates have sued to correct underrepresentation of ininorities on police forces, Asian Americans have often not been included in the lawsuits. ${ }^{109}$ As a result, they have not been included in any corrective ineasures following the lawsuit. ${ }^{110}$

Coverage, although problematic, is not fatal. It can be corrected if civil rights advocates consider the needs of Asian Americans. The theo-

106. Neil Gotanda, "Other Non-Whites" in American Legal History, 85 Colum. L. REv. 1186, 1188 (1985) (reviewing PETER Irons, JUsTICE AT WAR (1983)) (urging an examination of the "notion of 'foreignness'" often associated with the racial identity and legal status of "Other nonWhites").

107. Other commeutators have noted the problems created by comparing two different forms of discrimination. See, e.g., Trina Grillo \& Stephanie M. Wildman, Obscuring the Importance of Race: The Implication of Making Comparisons Between Racism and Sexism (or Other-Isms), 1991 DUKE L.J. 397, 401-10 (arguing that comparisons between racism and sexism may obscure the effects of racism and perpetuate patterns of racial domination).

108. For some methods used against Asian Americans in particular, see supra Parts I.A-B and infra Part III.

109. See Civil Rights Report, supra note 7, at 59.

110. For example, the Los Angeles Police Department, pursuant to a court order, must increase its representation of women, African Americans, and Hispanics. Id. at 59 n.53. Asian Americans are afraid to sue to be included in this consent decree because of the result in Martin v. Wilks, 490 U.S. 755 (1989), in which the Supreme Court recognized a right to challenge as discriminatory a consent decree that orders an employer to hire minorities. Asian Americans fear that if they seek to be included in the consent decree, the entire decree, which benefits other minorities, "could unravel." Civil Rights RePORT, supra note 7, at 59 n.53.

With the exception of San Francisco, most other cities have no measures in place to promote representation of Asian Americans in police forces. Id. at 59. The San Francisco Police Department 
retical difficulties present a greater problem. First, traditional civil rights work, with its foundation in liberal political philosophy, is based upon conceptions of individual rights. ${ }^{111}$ These rights are premised on the notion of an individuated autonomous self. ${ }^{12}$ However, this individuated autonoinous self inay not reflect the reality of all Asian Americans and the cultures from which they come. Many Asian philosoplies and cultures have at their center the concept of no-self. ${ }^{113}$ And at least one Asian language does not have a word for "I" that corresponds to "I" in English. ${ }^{114}$ Thus, for some Asian Americans, traditional civil rights work inay be at odds with their self-conception and worldview.

Furthermore, traditional civil rights work has often resulted in court opinions advocating color-blind constitutionahism, which provides only incremental improvement while legitimizing white racial domination. ${ }^{115}$ Thus, civil rights work, while providing some important benefits, will ultimately be unable to meet the needs of Asian Americans because of its coverage and theoretical problems. ${ }^{116}$

\section{Critical Race Scholarship}

Critical race scholarship presents only a problem of coverage for Asian Americans. Critical race scholars understand that differences

is operating under a consent decree designed to encourage the hiring of people bilingual in Chinese. Id.

Another example of failure to include Asian Americans in civil rights measures can be seen in the history of the Voting Rights Language Assistance Act. See infra Part III.A.2.

111. See, e.g., Ronald Dworkin, LAw's EMPIRE $381-87$ (1986) (discussing three forms of constitutional rights against discrimination).

112. See Robin West, Jurisprudence and Gender, 55 U. CHI. L. REv. 1, 5 (1988) (discussing the autonomous individual celebrated by liberal legalism).

113. See, e.g., Walpola S. Rahula, What the Buddha Taught 51-66 (rev. ed. 1974) (describing the doctrine of Anatta, which maintains that the notion of "self" is false and that all evil in the world can be traced to the idea of self). There is a large body of literature, much of it from critical legal scholars, that criticizes liberalism's celebration of individualism. See, e.g., ROBERTO M. UNGER, KNOWLEDGE AND POLITICS 277-78 (1975).

114. "In the Vietnamese language, "the word "I" (toi) ... means "your servant"; there is no "I" as such. When you talk to someone, you establish a relationship.'" Patricia Williams, SpiritMurdering the Messenger: The Discourse of Fingerpointing as the Law's Response to Racism, $42 \mathrm{U}$. Miami L. Rev. 127, 140 (1987) (quoting Daniel. BerRigan \& Thich Nhat HaNH, The Raft is NOT THE SHORE 38 (1975)).

115. See Neil Gotanda, A Critique of "Our Constitution is Color-Blind," 44 STAN. L. REv, 1 (1991); see also Alan D. Freeman, Legitimizing Racial Discriminavion Through Antidiscrimination Law: A Critical Review of Supreme Court Doctrine, 62 MinN. L. REv. 1049 (1978) (tracing the Court's post-Brown approach to discrimination and maintaining that a focus on rights often legitimizes oppression). Many minority scholars have criticized critical legal studies scholars, such as Freeman, for their insensitivity to minorities' reliance on rights. See, e.g., Richard Delgado, The Ethereal Scholar: Does Critical Legal Studies Have What Minorities Want?, 22 HARV. C.R.-C.L. L. REv. 301, 30 (1987) (criticizing CLS attacks on rights and noting that CLS fails to offer substitute protection).

116. Cf. Crenshaw, supra note 10, at 1368 (recognizing the importance of rights for African Americans). 
between racial minorities are important. ${ }^{117}$ However, these differences have yet to be fully developed. As a result, critical race scholarship tends to focus on the black-white racial paradigm, excluding Asian Americans and other racial minorities. For example, in a recent Colloquy entitled Racism in the Wake of the Los Angeles Riots, ${ }^{118}$ the Korean AmericanAfrican American conflict was not addressed, with the exception of two footnotes in one article ${ }^{119}$ and a discussion of the actions taken by the Korean government to try to protect Korean citizens and immigrants in another article. ${ }^{120}$ Nor were the perspectives of Korean Americans represented. These are serious omissions. ${ }^{121}$ The result is that the Colloquy, and more generally, the discourse on race and the law, is not as rich or coinplete as it might or should be. These omissions foreclosed the possibility of reaching a greater understanding of why the racial tensions exist, how they have been fostered by legal decisions, and what might be done to bridge the differences.

To focus on the black-white racial paradigm is to inisunderstand the complicated racial situation in the Umited States. It ignores such things as nativistic racism. It ignores the complexity of a racial hierarchy that has more than just a top and a bottom.

Asian American Legal Scholarship has a vested interest in helping to flesh out the racial paradigm. Asian American Legal Scholarship is needed to address the coverage problem in both traditional civil rights work and in critical race scholarship. ${ }^{122}$ Perceptions fostered by the model minority myth contribute to the lack of coverage. Thus, one of the tasks of Asian American Legal Scholarship is to break the silence that surrounds our oppression. An important tool in breaking this silence is the use of personal narrative. Narrative will allow us to speak our oppression into existence, for it must first be represented before it can be erased. ${ }^{123}$

117. See Calmore, supra note 15, at 2171-72.

118. Colloquy, Racism in the Wake of the Los Angeles Riots, 70 DENV. U. L. REv. 187 (1993) (including contributions by The Honorable A. Leon Higginbotham, Jr., The Honorable Nathaniel R. Jones, Jerome Culp, Henry Richardson, Deborah Post, Lynn Curtis, Kimberlé Crenshaw, Gary Peller, and Anthony Cook).

119. Jerome M. Culp, Jr., Notes from California: Rodney King and the Race Question, 70 DENV. U. L. REv. 199, 202 nn.8-9 (1993).

120. Henry J. Richardson, III, The International Implications of the Los Angeles Riots, 70 DENV. U. L. REv. 213, 225-26 (1993).

121. The individual authors are not to be blamed for these omissions. It is only when the Colloquy is looked at as a whole that one notices the omissions.

122. Claiming that there is a need for an Asian American Legal Scholarship is not an indictment of critical race theory. As I stated earlier, the problem with critical race scholarship has thus far been one of coverage, not theory.

123. I borrow this phrase from Barbara Johnson who said, "Difference . . . must be represented in order to be erased." Barbara Johnson, Thresholds of Difference: Structures of Address in Zora Neale Hurston, in "RACE," WRITING, AND DifFerenCE, supra note 7, at 317, 323. 
But before narrative can be used in this way, a space must be created for its use in legal discourse.

II

\section{NARRATIVE SPACE}

No discourse takes place in a vacuum; each situates itself, or is situated, within a certam space. ${ }^{124}$ A new discourse must create a space within which to operate. ${ }^{125}$ Asian American Legal Scholarship, as a new discourse, is no exception-it too must create a space, showing its relation to other discourses. Some of this work has already been done. In the previous Part, I showed that Asian American Legal Scholarship is, to an extent, a response to the madequacy of the current discourse on race and the law. It fills the gap created by the problems of coverage and theory in traditional civil rights work and the problem of coverage in critical race scholarship to date. Asian American Legal Scholarship creates its space out of this gap.

Asian American Legal Scholarship contends that personal narrative $^{126}$ is an important tool in addressing the oppression of Asian

124. See Ronald Dworkin, Law as Interpretation, 60 TEx. L. REv. 527 (1982). Dworkin draws an analogy between the constraints of legal analysis and the constraints facing a group of novelists who draw lots for the writing of a chain novel: "The lowest number writes the opening chapter of a novel, which he or she then sends to the next number who adds a chapter, with the understanding that he is adding a chapter to that novel rather than beginning a new one, and then sends the two chapters to the next number, and so on." Id. at 541. He acknowledges, though, that even the first novelist is not entirely without constraint because that novelist "has the responsibility of interpreting to the extent any writer inust, which includes not only interpreting as he writes but interpreting the genre in which he sets out to write." Id. at 541 n.6.

Professor Stanley Fish emphasizes this point in his critique of Dworkin's "chain enterprise":

One cannot think of beginning a novel without thinking within, as opposed to thinking "of," these established practices, and even if one "decides" to "ignore" them or "violate" them or "set thein aside," the actions of ignoring and violating and setting aside will themselves have a shape that is constrained by the preexisting shape of those practices. Stanley Fish, Working on the Chain Gang: Interpretation in Law and Literature, 60 TEX. L. REV. 551,553 (1982)

125. Cf. Fish, supra note 124 , at 553 . In discussing the constraints on the first novelist, Fish adds:

This does not mean that the decisions of the first author are wholly determined, but that the choices available to him are "novel writing choices," choices that depend on a prior understanding of what it means to write a novel, even when he "chooses" to alter that understanding. In short he is neither free nor constrained (if those words arc understood as referring to absolute states), but free and constrained. He is free to begin whatever kind of novel he decides to write, but he is constrained by the finite (although not unchanging) possibilities that are subsumed in the notions "kind of novel" and "beginning a novel." Id. (footnote ounitted).

126. Personal narrative, or "minority discourse" as it was formerly known, developed in response to the exclusion of the disempowered from mainstreain academic discourse. See Abdul R. JanMohamed \& David Lloyd, Introduction: Minority Discourse-What Is to Be Done?, 7 CuLTURAL Critique 5 (1987). As minority discourse arises out of exclusion, "we must realize that [it] is, in the first instance, the product of damage, of damage more or less systematically inflicted on cultures produced as ininorities by the dominant culture." Id. at 7. However, to call it a product of damage is not the same as to call it a damaged product. Instead, the damage has been transformed into a 
Americans. Narrative occupies a similar role in both femimist legal theory and critical race theory. ${ }^{127}$ However, the use of narrative has been and continues to be debated in the context of those two disciplines. ${ }^{128}$ Thus, Asian American Legal Scholarship cannot use narrative effectively without first clearing space for its use.

This lack of space can partly be attributed to the way the discourse on the use of narrative in outsider legal scholarship has been captured by a focus on the existence of a different voice. This preoccupation with "voice" sparked the rather acrimomious Racial Critiques Debate. ${ }^{129}$ Professor Alex Jolinson attempts to put an end to this debate by positimg that every scholar of color speaks $\mathrm{m}$ the voice of color. ${ }^{130}$ That this attempt at closure was unsuccessful is evidenced by a recent article by Professors Farber and Sherry who criticize the use of narrative by feminist legal and critical race scholars beçause these scholars have not yet proved by empirical evidence the existence of a different voice. ${ }^{131}$

positive: the oppressed may claim an access to a truth that is not available to the oppressor. Id. at 10-11. This is one of the messages of minority discourse. Although JanMohamed and Lloyd do not use the term "standpoint epistemology," their discussion about the insights available only to the oppressed is similar to the claim of standpoint epistemologies which will be discussed infra notes 188-98 and accompanying text.

127. Narrative often appears in forms of legal scholarship that Mari Matsuda calls "outsider jurisprudence," where she uses "outsider" instead of "minority" because the latter term "belies the numerical significance of the constituencies typically excluded from jurisprudential discourse." Mari J. Matsuda, Public Response to Racist Speech: Considering the Victim's Story, 87 MicH. L. REv. 2320, $2323 \&$ n.15 (1989). Outsider jurisprudence includes feminist jurisprudence and the jurisprudence of people of color. Id. at 2323.

Narrative also appears in the the law and literature movement. See, e.g., James B. White, Law and Literature: "No Manifesto," 39 MERCER L. Rev. 739 (1988); James B. White, Law as Language: Reading Law and Reading Literature, 60 TEx. L. Rev. 415 (1982). An important difference, though, between the law and literature movement and storytelling in "outsider jurisprudence" is that the former talks about narrative and the latter "does" narrative. Compare James B. White, Law as Language: Reading Law and Reading Literature, supra (arguing that a legal text is like a literary text, in that each is subjeet to interpretation and has no determinate meaning) with Patricia J. Williams, Alchemical Notes: Reconstructing Ideals From Deconstructed Rights, 22 HARV. C.R.-C.L. L. REV. 401 (1987) (weaving stories and meta-stories about herself and the law to critique critical legal studies). I point out this difference to separate these movements, not to criticize the law and literature movement.

128. For some recent exchanges, see Kennedy, supra note 5, and Colloquy, Choosing Sides in the Racial Critiques Debate, 103 HARv. L. Rev. 1844 (1990) (contributions by Scott Brewer, Milner Ball, Robin Barnes, Richard Delgado, and Leslie Espinoza) (responding to Kennedy); Tushnet, supra note 6, and Peller, supra note 6 (responding to Tushnet); Daniel A. Farber \& Suzanna Sherry, Telling Stories Out of School: An Essay on Legal Narratives, 45 StAN. L. REv. 807 (1993), and Richard Delgado, On Telling Stories in School: A Reply to Farber and Sherry, 46 V AND. L. REV. 665 (1993) (responding to Farber and Sherry). For another discussion of outsider scholarship, see Mary I. Coombs, Outsider Scholarship: The Law Review Stories, 63 U. Colo. L. ReV. 683 (1992).

129. See supra note 128.

130. Alex M. Johnson, Jr., The New Voice of Color, 100 YALE L.J. 2007, $2061-62$ (1991) ("[T]he development and evolution of Critical Race Theory and the concomitant emphasis on race consciousness during the last score of years lends considerable support to the existence of a voice of color. Consequently, ... I contend that the debate over the existence of the voice of color has concluded.") (footnotes omitted).

131. See Farber \& Sherry, supra note 128 , at $809-19$. They note that 
In a response to Farber and Sherry, Professor Richard Delgado correctly identifies that "[v]oice is a false issue." ${ }^{132}$ I would go further and say that by focusing on the existence of a different voice, Farber and Sherry have created the equivalent of an essentialist trap. A direct refutation of their argument, by positing the existence of a different voice for women and people of color, would be subject to charges of essentialism, which many feminists and critical race scholars reject. ${ }^{133}$ Moreover, Farber and Sherry fail to take into account that feminist theory has, for the most part, moved beyond the different voice debate and accepted the existence of different voices. ${ }^{134}$ It is time now for critical race theory to do the same, to move beyond the different voice debate, because the use of narrative need not depend on a different voice thesis.

The argument I put forth is not unique to Asian American Legal Scholarship, ${ }^{135}$ but I make the argunient here because space must be created for Asian American Legal Scholarship's use of narrative. I begin by showing that perspective matters. I then briefiy describe resistance to outsider stories. In the face of this institutional disapproval, outsiders can either conform to the doninant objective mode of discourse or continue telling their stories. One problen with the former is that many

although some evidence exists that men and women possess different perspectives on the law, the weight of the evidence does not support either of the strong versions of the different voice thesis: i) that the voices of men and women are so different that the former normally can neither understand nor evaluate the work of the latter, or ii) that women are in a unique position to transform legal scholarship.

Id. at 814. Moreover, Farber and Sherry assert that no evidence of a voice of color has been presented. Instead, "[m]ost critical race theorists simply postulate the existence of a difference, often citing feminist scholarship for support, and thus implicitly equating a male voice with a white voice." Id.

132. Delgado, supra note 128 , at 669 .

133. See, e.g., Culp, supra note 15 , at 73 (rejecting essentialism in racial scholarship); Harris, supra note 13 (rejecting gender essentialism).

134. Carol Gilligan's different voice thesis, positing the existence of two moral orientations, relied on Nancy Chodorow's psychoanalytic object-relations theory, which accounted for greater individuation in boys than in girls. See Carol Gllligan, IN A Different Volce: Psychological Theory and Women's Development 8 (1982) (citing Nancy Chodorow, THE REPRODUCTION OF MOTHERING: PSYCHOANALYSIS AND THE SOCIOLOGY OF GENDER 166.67 (1978)). Feminist theory has developed other accounts, such as feminist standpoint epistemologies, see infra text accompanying note 189 , and postmodern feminism focuses on different notions of identity construction, which result in multiple or fractured identities:

Identities seem contradictory, partial, and strategic. With the hard-won recognition of their social and historical constitution, gender, race, and class cannot provide the basis for belief in "essential" unity. There is nothing about being "female" that naturally binds women. There is not even such a state as "being" female, itself a highly complex category constructed in contested sexual scientific discourses and other social practices.

Donna Haraway, A Manifesto for Cyborgs: Science, Technology, and Socialist Feminism in the 1980s, in FemINISM/PostmodernisM 190, 197 (Linda J. Nicholson ed., 1990).

135. Narrative may not be the exclusive domain of outsiders. See Farber \& Sherry, supra note 128 , at 813 (noting that writers "have eloquently described storytelling by other cultures and other voices, including those of white males"). That narrative is not the exclusive domain of outsiders does not diminish the importance of our stories to scholarship. 
people find this dominant objective voice to be foreign. ${ }^{136}$ In addition to being foreign, the dominant voice may not adequately capture the power and intensity of dealing with racisin as effectively as a narrative-based legal scholarship can. ${ }^{137}$ In order to pursue the latter course, however, the case inust be made for narrative. ${ }^{138}$ I describe two strategies for validating narrative. The first, and as I will argue, ultiinately unsuccessful, stategy takes place within the rational/empirical mode. ${ }^{139}$ The second strategy takes place within post-modern or post-structural theory. ${ }^{140} \mathrm{By}$ placing the use of narrative squarely on post-structural theory, I hope to dispel the notion expressed by one cominentator that "postinodern "theory' can be perceived as the discourse of privileged members of society who claim to explain and justify different voice scholarship and, in so doing, atteinpt to colonize the writing of minorities and outgroup meinbers." 141

136. For example, "The very forms of the dominant mode of discourse show the mark of the dominant masculine ideology. Hence, when a woman writes or speaks herself into existence, she is forced to speak in something like a foreign tongne, a language with which she may be personally uncomfortable.' " Elaine Showalter, Feminist Criticism in the Wilderness, in THE NEw FEMINIST Criticism 243, 253 (Elaine Showalter ed., 1985) (quoting Carolyn G. Burke, Report from Paris: Women's Writing and the Women's Movement, 3 SIGNs 844 (1978)).

137. Two other reasons exist for the disempowered to continue telling our stories. First, storytelling can serve as a "means of psychic self-preservation." Richard Delgado, Storytelling for Oppositionists and Others: A Plea for Narrative, 87 MiCh. L. Rev. 2411, 2436 (1989). The marginalized often internalize oppression and blame ourselves for our failings. Id. at 2437. Storytelling provides a cure by helping us to understand that our failings are not always our fault, that they often result from historic and present-day oppression. Id. Listening to these stories can help us to discover that we are like Ralph Ellison's protagonist in Invisible Man, that our invisibility only "occurs because of a peculiar disposition of the eyes of those with whom [we] come in contact. A matter of the construction of their inner eyes, those eyes with which they look through their physical eyes upon reality." RALPH ElLison, INVISIBLE MAN 3 (1947). This realization can be liberating. Second, storytelling promotes solidarity. As we tell our stories and as we hear other people's stories, we realize that we are not alone. Delgado, supra at 2437.

138. See Farber \& Sherry, supra note 128, at 831 n.127 ("[I]n order for storytelling to be considered legal scholarship, it has to play by the rules as they exist or at least provide a cogent argument for changing them.").

139. See infra notes $180-203$ and accompanying text.

140. See infra notes 204-15 and accompanying text.

141. Stephen M. Feldman, Send in the Clowns: Postmodernism, Legal Scholarship, and the Teague Rule Against New Rules in Habeas Corpus Cases 349 (unpublished manuscript, on file with Geongetown Law Journal; cited in Tushnet, supra note 22, at 343 n.1). There is, of course, the argument that $\mathrm{I}$, as a minority voice scholar, have been co-opted by using post-structural theory. Professor Jane Tompkins writes about this same problem in the context of feminism:

Not long ago, as organizer of an MLA session entitled "Professional politics: women and the institution," I urged a large roomful of women to "get theory" because I thought that doing theory would admit us to the big leagues and enable us at the same time to argue a feminist case in the most unimpeachable terms-those that men had supplied. I busily took my own advice, which was good as far as it went. But I now see that there has been a price for this, at least there has been for me .... I now tend to think that theory itself, at least as it is usually practiced, may be one of the patriarchal gestures women and men ought to avoid.

Jane Tompkins, Me and My Shadow, in GENDER AND THEORY, supra note 15, at 121, 122. This dynamic has been replayed throughout history. For example, Alexander Crummell, who founded the American Negro Academy in 1897, said that the "acquisition of [the English language] is 


\section{A. Perspective Matters}

When the legal academy was made up exclusively of white males, a legal scholar did not have to reveal the context from which he spoke because everyone occupied the same context. This shared context fostered a false sense of acontextuality, where one could pretend to be aperspectival because only one perspective was represented. ${ }^{142}$ With the entry of women and persons of color into the legal academy and with their use of personal narratives im scholarship, whether perspective matters has become a contested issue.

Other disciplines recognize the importance of perspective. ${ }^{143}$ Even science, once the model for the study of law, ${ }^{144}$ has recognized that the perspective of the observer inatters. ${ }^{145}$ For example, there was a longstanding dispute among physicists about whether light was a wave or a particle. ${ }^{146}$ Adherents of the wave theory, limited by their perspective, were unable to see that hight sometimes behaved like a particle. Likewise, adherents of the particle theory were unable to see that light sometimes behaved like a wave. Each group was unable to see what the other group saw; the groups were unable to see that light could be both wave and particle. ${ }^{147}$

Just as science has learned that the perspective of the observer can

elevation." Henry L. Gates, Jr., Authority, (White) Power and the (Black) Critic, 7 Cultural CRITIQUE 19, 22 (1987) (quoting Alexander Crummell, The English Language in Liberia, in THE FUtURE of AFrica 35 (New York, Scribner 1862)). Crummell, unlike Tompkins, never reconsidered.

142. I may overgeneralize, but there certainly was not a diversity of political opinions within the legal academy at that time. Even today, the range from liberal to conservative within American legal theory does not begin to approach diversity because both viewpoints are based on liberal political philosophy, which celebrates the individuated, autonomous self. One important exception is critical legal studies, which has launched a devastating, sustained critique of mainstream liberal legal thought. See generally MARK Kelman, A Guide to Critical Legal Studies (1987).

143. See, e.g., Clifford GeERTZ, LoCAL KNowledge 57 (1983) (discussing perspective in anthropology and the challenge "to produce an interpretation of the way a people lives which is neither imprisoned within their mental horizons, an ethnography of witchcraft as written by a witcl, nor systematically deaf to the distinctive tonalities of their existence, an ethnography of withchcraft as written by a geometer"); NANCY K. Miller, GetTing PERSonal: Feminist Occasions and OtHer AUTOBIOGRAPHICAL ACTs 32 (1991) ("It is the fashion in French literary circles . . . to inquire of a speaker (or, if one is the speaker, to identify) the locus of one's discourse, to name the place out of which one speaks.").

144. Christopher Langdell thought that legal principles could be deduced from cases in the same way that scientific observation revealed laws of nature. CHristopher C. LANGDELL, A SELECTION OF CASES ON THE Law OF CoNTRACTS viii (2d ed., Boston, Little, Brown \& Co. 1879).

145. See Laurence H. Tribe, The Curvature of Constitutional Space: What Lawyers Can Learn From Modern Physics, 103 HARV. L. REv. 1, 17-19 (1989) (discussing the importance of perspective to the Heisenberg Uncertainty Principle in quantum theory).

146. See Thomas S. Kuhn, The Structure of Scientific Revolutions 12-13 (2d ed. 1970). I use examples from science because science has often served as a model for those who believe in objectivity.

147. Id. at 114. A new paradigm, wave mechanics, eventually came to explain the phenomenon. Id. 
not only affect, but can also determine, what is observed, law must also recognize the importance of perspective. Professor Laurence Tribe reminds us, "[d]ifficult as it is to view the world from someone else's perspective, not to make the effort is to ignore what science learned long ago."148

The lesson from science for the legal academy is simple: Listen.

\section{B. Resistance to Narrative}

Although more scholars are beginning to use personal narrative, this development has been accompanied by warnings from mainstream academia about how these narratives should be presented. With these warnings, ${ }^{149}$ storytelling becomes a risky scholarly endeavor because the stories are not accepted as evidence or, at best, are placed in the category of anecdotal evidence which does not occupy a privileged place in the law. ${ }^{150}$

This concern about the anecdotal nature of personal narrative manifests itself in resistance and doubt from audiences when they hear stories from critical race scholars. For example, when Professor Patricia Williams tells her now infamous Benetton story, ${ }^{151}$ the audience forces her to answer such questions as the following:

Am I not privileging a racial perspective, by considering only the black point of view? Don't I have an obligation to include the "salesman's side" of the story?

How can I be sure I'm right?

What makes my experience the real black one anyway?

Isn't it possible that another black person would disagree with my experience? If so, doesn't that render my story too

148. Tribe, supra note 145 , at $38-39$.

149. See, e.g., Farber \& Sherry, supra note 128; Tushnet, supra note 6.

150. Cf. Tushnet, supra note 6 , at 260 (suggesting that "real life stories in narrative jurisprudence [can] resemble the telling anecdotes of talented journalists"). This problem is exacerbated by professional taboos against self-revelation, see Showalter, supra note 136, at 252, which force many academics to conform to the objective mode of discourse, particularly those academics seeking tenure. Nancy Miller writes that "[a]cademic women wanting jobs and tenure (and most of us did) conformed to the 'critical plausibility' of their scene and cohort which required an objective style." MILLER, supra note 143, at 15; see also Coombs, supra note 128, at 690 (describing how interviews with roughly two dozen outsider legal scholars revealed that many were worried that doing nontraditional scholarship would hurt their chances for tenure).

151. She was shopping on a Saturday afternoon in New York. She saw a sweater that she wanted to buy in a Benetton store window. This store, like many others in the city, had adopted a buzzer system. The doors were locked, and a store employee would buzz in customers. When Williams, who is African American, pushed the buzzer and requested admission, the store employee saw Williams' face. He then mouthed the words, "We're closed," even though there were several white people shopping inside and it was two Saturdays before Christmas. Williams, supra note 114, at 128. 


\section{unempirical and subjective to pay any attention to ${ }^{152}$}

These questions are similar to the questions I face when I tell my stories. I usually keep these stories to myself because when I tell them to people, I often hear doubt in their voices and their questions. How do you know it was racism? How do you know that the same thing would not have happened to anyone else? They question the details. Did you really see the border guard smirk? How do you know that the service station was not out of gas? But I am ready for their questions. I have prepared answers. The car before me at the service station got gas, and the white man in the car in front of me at the border crossing did not have a problem with his driver's license. Yes, I could see that far away; I have good vision. As the questions keep coming, I reahze that people do not want to beheve me. They do not want to see racism because it is ugly. They have learned or convinced themselves that such ugliness does not exist, at least not in such blatant forms, and not to Asian Americans. ${ }^{153}$ From their perspective, since Asian Americans do not suffer from discrimination, I must be mistaken, deluded, ${ }^{154}$ or lying. And even if they believe my stories, they discount them as isolated incidents. ${ }^{155}$

\section{Although these questions that Patricia Williams and I face represent}

152. Patricia J. Williams, The Alchemy of Race and Rights 50-51 (1991).

153. I have noticed that responses tended to vary depending on the gender and race of the listener. From my own unscientific observations, I recognized that stories were often better received by people of color and by women than by white men. Perhaps this is not surprising. For example, Lynne Henderson notes:

The reality of empathy is that we are more likely to empathize with people similar to ourselves, and that such empathic understanding may be so automatic that it goes unnoticed: elites will empathize with the experience of elites, men empathize with men, women with women, whites with whites. I would call this "unreflective" empathy. Empathy for those unlike oneself is, indeed, "more work," but certainly it is not impossible.

Lynne N. Henderson, Legality and Empathy, 85 Mich. L. REv. 1574, 1584 (1987) (footnote omitted).

154. In the context of feminism, there are several studies of delusion as a mechanism for control. See, e.g., Elaine Showalter, The Female Malady: Women, Madness, and English Culture, 1830-1980 (1985). Professor Showalter notes:

During the decades from 1870 to 1910 , middle-class women were beginning to organize in

[sic] behalf of higher education, entrance to the professions, and political rights. Simultaneously, the female nervous disorders of anorexia nervosa, hysteria, and neurasthenia became epidemic; and the Darwinian "nerve specialist" arose to dictate proper feminine behavior outside the asylnm as well as in, to differentiate treatments for "nervous" women of various class backgrounds, and to oppose women's efforts to change the conditions of their lives.

Id. at 18. Critical race theory could follow feminist theory's examplc and examine how the dominant culture uses delusion to deny or refute the claims of minorities.

155. That stories about discrimination against Asian Americans are discounted can bc blamed in part on the media and their failure to cover hate crimes against Asian Americans. See Civil. Rights RePORT, supra note 7, at 28 \& n.40 (describing the murder of a Chinese Ameriean, Jim Loo, and quoting a commentator who stated that, "[u]nlike most civil rights prosecutions, [Loo's murderer's trial] passed virtually unnoticed, despite its being only the second Federal civil rights prosecution involving an Asian victim. Compare this lack of coverage to the steady flow of reports 
common concerns when we use stories in a discourse on law, there are important differences. While people usually concede that African Americans suffer from discrimination, they often question the extent or pervasiveness of it. ${ }^{156}$ For Asian Americans, however, people do not even reach the question of extent because the majority of Americans do not believe that Asian Americans suffer from discrimmation. ${ }^{157}$ Nor is this false belief in the Asian American inodel minority myth confined to the general public-it has infected government officials and members of the judiciary. ${ }^{158}$ This creates different problems for legal storytellers when they speak about Asian American problems.

Professor Kathryn Abrams speaks generally about these concerns in an article entitled Hearing the Call of Stories. ${ }^{159}$ She describes these concerns as challenges to "truth" and "typicality." 160 She uses "truth" in the common sense and "typicality" in the sense of "umiversality" or "statistical significance." 161 Thus, if the narrative is not true or not typical, it cannot serve as the basis for legal change. Abrains then discusses aspects of various narratives that make thein either believable or problematic. ${ }^{162}$ From this, she concludes

that there are inultiple ways that a narrative can achieve credibility-through revealed pain, through the cohering, particularized knowledge of the expert witness, through the ignition in the reader of a flash of recognition - and that many narratives already do satisfy the criterion on which challengers had argued they fell short. ${ }^{163}$

While Professor Abrams provides useful categories and terms for discussing and evaluating narratives, she does not sufficiently address what happens when readers are "eager to discount, discredit, or otherwise distance themselves from such discussions."164 In such a situation, pointing out to "challengers" that the narrative is credible because it contains "revealed pain" or "cohering, particularized knowledge of the

about Asian gangs, drugs and gambling.") (quoting Helen Zia, Another American Racism, N.Y. TIMES, Sept. 12, 1991, at A25).

156. Charles R. Lawrence III, If He Hollers Let Him Go: Regulating Racist Speech on Campus, 1990 DUKE L.J. 431, 478-79.

157. See supra note 11.

158. See supra Part I.B.

159. Kathryn Abrams, Hearing the Call of Stories, 79 CaLIf. L. REv. 971 (1991).

160. Id. at $978-79$.

161. Id. at 980 . The "typicality" challenge seems to misunderstand the range of uses narrative can serve in legal discourse.

162. Id. at 982-1012. She discusses the following articles: Susan Estrich, Rape, 95 YALE L.J. 1087 (1986); Martha R. Mahoney, Legal Images of Battered Women: Redefining the Issue of Separation, 90 Mich. L. REv. 1 (1991); Patricia Williams, The Obliging Shell: An Informal Essay on Formal Equal Opportunity, 87 MrcH. L. REv. 2128 (1989); and Marie Ashe, Zig-Zag Stitching and the Seamless Web: Thoughts on "Reproduction" and the Law, 13 NovA L. REv. 355 (1989).

163. Abrams, supra note 159 , at 1024.

164. Id. at 979. Professor Abrams mentions this early in her article but does not return to it. 
expert witness" or "the ignition in the reader of a flash of recognition" may not persuade a challenger to drop the challenge. This concerns me because with race narratives, the race of the narrator and the race of the reader play an important role in whether the narrative will be taken as credible. ${ }^{165}$ Race narratives, when directed toward the dominant group, almost always challenge the dominant group's belief system, especially when the race narratives are told by critical race scholars. In such a situation, a more compelling reason to listen to and to consider seriously narratives must exist other than that the narratives do what Abrams claims they accomplish. In other words, an arguinent based on narrative integrity is insufficient to convince a reader to consider seriously the message of the narrative. ${ }^{166}$

In a recent article about the use of narratives in legal discourse, Professors Daniel Farber and Suzanna Sherry echo some of Professor Abrams' concerns about truth and typicality. ${ }^{167}$ They differ, though, in their characterization of the truth issue. ${ }^{168}$ Farber and Sherry claim that "[t]he real question here is not objective 'truth,' but honesty."169 They distinguish three different statements that can be made about a described event:

(1) "If you had been watching, this is what you would have seen";

(2) "The situation might not have looked this way if you had been watching, but this is how it felt to me"; and

(3) "The situation didn't feel this way to me at the time, but this is how it seems to me now."170

They then say that "since the first standard is the ordinary understanding of truth, it would be dishonest to present statements that are only true

165. Racism influences the way people perceive others. If the reader is consciously or subconsciously biased against the narrator because of her race, this bias will likely affect the reader's perception of the narrator's credibility. This problem is perhaps unavoidable because everyone has to some extent been affected by the "common historical and cultural heritage in which racism has played and still plays a dominant role . . . [and t]o the extent that this cultural belief system has influenced all of us, we are all racists." Lawrence, supra note 75, at 322 (footnote omitted). Furthermore, racism is so pervasive, so omnipresent that it is not just a part of social reality-it is social reality. See Lawrence, supra note 156 , at 443 . Catharine MacKinnon makes a similar argument in a feminist critique: "To the extent pornography succeeds in constructing social reality, it becomes invisible as harm." Catharine A. MacKinnon, TOWARd a FEMINist TheORY OF THE STATE 204 (1989).

166. But see Tushnet, supra note 6, at 251 (arguing that integrity and judgment are the key to effective narratives).

167. See Farber \& Sherry, supra note 128 , at $832-40$ (discussing truth and typicality).

168. See id. at 834 ("[W]e . . . reject Kathryn Abrams' argument that it would be untroubling, at least with respect to narratives that are presented as factual, if they were to turn out 'not to track the life experiences of their narrators in all particulars' or to be composites.") (quoting Abrams, supra note 159 , at 1025$)$.

169. Id. at 833 .

170. Id. 
under the second or third standards without an explicit disclaimer."171 The unstated corollary is that it would be honest, such that one need not provide a disclaimer, if your claim is, "If you had been watching, this is what you would have seen." But this claim can be true if (and only if) the perspective of the observer is irrelevant. This is true if (and only if) an objective account is being rendered. Thus, despite the claim otherwise, this argument about honesty is really about objective truth. The result, then, is that their argument fails to hit the mark because they do not address the "real question."172

When the real question about objectivity is asked, further questions are revealed. What counts as knowledge? What counts as evidence? One use of outsider stories is to demonstrate the inequities of the present situation. The disempowered find ourselves in a peculiar position in that the evidence we would use to prove our oppression consists of the very stories that are now disbelieved or excluded because they are only stories. In this way, rules of evidence silence us. In order to get our stories into evidence, we need to broaden or change the very meaming of evidence. ${ }^{173}$ In order to make the case for narrative, I turn now to epistemology because our theory of knowledge largely determines what counts as knowledge and what counts as evidence.

171. Id.

172. They also fail to hit the mark in their ultimate conclusion when they advise would-be storytellers to include reasoned argument with our stories. Id. at 854 ("A legal story without analysis is much like a judicial opinion with 'Findings of Fact' but no 'Conclusions of Law." "). To prepare for this conclusion, they ask, "[C]an an unadorned account of personal experiences, standing alone, constitute good scholarship?" Id. at 849. They answer, "Unlike many current legal storytellers, we conclude that it cannot." Id.

Their conclusion implies that many current legal storytellers believe that unadorned accounts of personal experiences constitute good scholarship. Yet, if one reads the work of current legal storytellers, one rarely, if ever, finds such unadorned accounts. Because Farber and Sherry do not cite any legal storytellers who present unadorned accounts of personal experiences as legal scholarship, it is unclear whom they have in mind. An examination of the work of current and past legal storytellers shows that their work included analytic components. See, e.g., BELL, supra note 19 (presenting reasoned arguments through fictionalized dialogues); THE COLLECTED DIALOGUES OF Plato (Edith Hamilton \& Huntington Cairns eds. \& Lane Cooper et al. trans., 3d prtg. 1964) (same); WiLliams, supra note 152 (using autobiography interwoven with analysis to illustrate problems in law, law school, and society); Mari J. Matsuda, Voices of America: Accent, Antidiscrimination Law, and a Jurisprudence for the Last Reconstruction, 100 YALE L.J. 1329 (1991) (telling stories of accent discrimination victims and then providing doctrinal analysis). Thus, Farber and Sherry's statement is misleading.

173. We need a definition of evidence analogous to the federal evidence rule of selfauthentication. This rule provides that certain documentary evidence may be admitted without extrinsic evidence. FED. R. EvID. 902; cf. Abrams, supra note 159, at 1022 (describing "first-person agony narratives" that compel the reader's belief because "[t]he author's willingness to expose herself to social stigma through revelation of the painful experience . . . convey[s] to the reader the author's belief in the importance of her message"). 


\section{Epistemological Strategies}

There seem to be two ways to argue the case for personal narrative. ${ }^{174}$ The first takes place within the rational/empirical mode. ${ }^{175}$ In this mode, an argument will be convincing if it meets certain standards of "iinpartiality, objectivity, evidential confirmation, comprehensiveness or completeness, and explanatory power."176 Personal narrative would be offered to challenge the current formulation of objectivity, but not the notion of objectivity itself. ${ }^{177}$ In this sense, personal narrative reveals bias in supposed objectivity and then reconstructs it to include previously excluded perspectives. Some strands of feminist theory and critical race theory have this as their goal and rely to some extent on a version of standpoint epistemology to legitimize the use of stories of oppression. I will examine these arguinents in Part II.C.1.

The second, more radical approach challenges the rational/empirical mode by challenging the very notion of objectivity and the accessibility of knowledge. This more radical critique is often characterized as post-modern or post-structural. ${ }^{178}$ In challenging the rational/empirical

174. The two ways correspond to the choice that one theorist envisions for feminism: a choice between the Enlightenment or post-modernism. According to Jane Flax, "[w]e cannot simultaneously claim (1) that the mind, the self, and knowledge are socially constituted and that what we can know depends upon our social practices and contexts and (2) that feminist theory can uncover the trnth of the whole once and for all." Jane Flax, Postmodernism and Gender Relations in Feminist Theory, in FEMINISM/POSTMODERNISM, supra note 134, at 39, 48.

175. I use the term "rational/empirical" to denote any mode of discourse characterized by the Enlightenment premise that objective knowledge is accessible. I use this term slightly differently than Katharine Bartlett does in her article Feminist Legal Methods, 103 HARv. L. REv. 829 (1990). She distinguishes standpoint epistemology from the rational/empirical mode, $i d$. at 867-77, but I will show that many standpoint epistemologies exist within the rational/empirical mode, while other standpoint epistemologies have a post-modern strain. See infra text accompanying notes 180-91, 212-15. I use "rational/empirical" rather than "modern" (in contradistinction to "post-modern") because modernism is a broader concept. Professor Patterson identifies three axes that provide modernism with a three dimensional perspective:

1. Epistemological Foundationalism: the view that knowledge can only be justified to the extent it rests on indubitable foundations;

2. Theory of Language: language has one of two functions-it represents ideas or states of affairs, or it expresses the attitudes of the speaker;

3. Individual and Community: "society" is best understood as an aggregation of "social atoms."

Dennis Patterson, Postmodernism/Feminism/Law, 77 CoRnell L. ReV. 254, 263 (1992).

Rational/empirical focuses on the epistemological foundationalism of modernism.

176. Alison M. Jaggar, Feminist Politics and Human Nature 354-55 (1983).

177. Mari Matsuda notes that "[t]he process of unmasking hidden centers and false objectivity is an important first step in producing a counter-ideology of antisubordination, as is acknowledging the psychology of dominance that accompanies subordination." Matsuda, supra note 172, at 1398.

178. Post-structuralism, a specific practice of theory, is a subvariety of post-modernism. See Fredric Jameson, Postmodernism, or the Cultural Logic of Late Capitalism xvi (1991). These terms are similar, and many theorists use them interchangeably, but just as I use "rational/ empirical" instead of "modern," I will use "post-structural" as the term specifically denoting an antifoundational epistemological stance.

These two approaches correspond to my earlier divisions. Traditional civil rights work relies on a rational/empirical epistemology; critical race theory relies on post-structural epistemology. 
mode, this more radical critique also challenges the standpoint epistemologies that might support the use of personal narrative. Since all standpoints are equally validated (or invalidated), there is no longer any coinpelling reason to privilege any viewpoint. To state it differently, my personal narrative is as relevant as your personal narrative, and since both of thein are equally relevant, they are equally irrelevant. ${ }^{179}$ I will examine how post-structural theory has responded to this challenge in Part II.C.2, but I turn now to the rational/empirical mode.

\section{Arguing in the Rational/Empirical Mode}

Mainstream academic legal discourse begins froin the premise that objective knowledge exists and is accessible. I call this the rational/ empirical position. My own theoretical bias tells ine that this is a false premise, but I start here to show how the case for personal narrative would appear within the context of inamstream academic discourse. ${ }^{180}$

Different disempowered groups have developed a similar inethodology that tries to reveal bias in supposedly neutral standards. Ferninist legal scholars ask "[ $t]$ he woinan question." They ask "about the gender implications of a social practice or rule: have women been left out of consideration? If so, in what way; how inight that oinission be corrected? What difference would it inake to do so?"181 Race scholars ask the race question, and so on. The use of the objective voice is one of the social practices that has come under the scrutiny of those asking this type of question.

The objective voice is obtained by abstracting from the individual in order to universalize the perspective of the author so that not only does the author, as an abstracted entity, speak as Everyman, the author also presumes to speak for everyone. A favorite device is the use of what one coininentator calls the "constitutive we."182 This "constitutive we" appears in the work of many philosophical and legal theorists. For example, John Rawls uses "we" in a subtle way that includes "us" as fellow inquirers into the questions he poses. ${ }^{183}$ But who does he think "we" is? 184

Too often, the individual used as the model for the universal is a man, and more specifically, a white inan. Thus, one goal of personal

179. See Harris, supra note 13, at 581-82. Professor Harris exemplifies this view by referring to a Borges short story, Funes, the Memorious. In the story, Funes becomes incapable of discriminating between experiences so that all experiences exist merely as particularities.

180. Starting here has other practical advantages. See Patterson, supra note 175, at 305 ("If the truth or falsity of a belief is a function of other beliefs, then one intent on changing current understanding is best advised to begin with the network of existing beliefs.").

181. Bartlett, supra note 175 , at 837 . She adds that "[a] question becomes a method when it is regularly asked." Id.

182. Kim L. Scheppele, Foreword: Telling Stories, 87 M1CH. L. REv. 2073, 2077 (1989).

183. JOHN RAWLS, A THEORY OF JUSTICE passim (1971).

184. I borrow this phrase from Elizabeth Spelman's article entitled, Simone de Beauvoir and 
narrative is to discredit this "we." For example, I might use personal narrative to show that the "we" is a lie because it does not include "me."

The stories of outsiders become important because they tell the story from different perspectives, perspectives that may have been excluded when formulating the objective, universal "we." It is important to remember that at this stage, personal narrative is not being offered to replace what had previously been thought of as objective: to impose my subjectivity upon everyone else only repeats the sin. ${ }^{185}$ Rather, personal narrative is being offered to show that objectivity may actually be a disguise for white male subjectivity, which takes away the subjectivity of the diseinpowered. ${ }^{186}$

One atteinpt to restore these lost subjectivities relies on a version of standpoint epistemology. An objectivist or liberal epistemology takes as the proper standpoint that of the "neutral, disinterested observer, a socalled Archimedean standpoint somewhere outside the reality that is being observed." 187 In contrast, standpoint epistemologies identify a certain group as victim and then "privileges that status by claiming that it gives access to understanding about oppression that others cannot have." "188 In the context of feminism, "[t]he feminist standpoint episteinologies argue that because men are in the master's position vis-à-vis woinen, women's social experience-conceptualized through the lenses of feminist theory - can provide the grounds for a less distorted understanding of the world around us." 189 This saine point can and has been inade about other oppressed groups. ${ }^{190}$ One question that arises is why

Women: Just Who Does She Think "We" Is?, in FEMINIST INTERPRETATIONS AND POLITICAL Theory 199 (Mary L. Shanley \& Carole Pateman eds., 1991).

Jane Tompkins questions Foucault on the use of "we" in his History of Sexuality. She says: Foucault is using the convention in which the author establishes common ground with his reader by using the first person plural-a presumptuous, though usually successful, move. Presumptuous because it presumes that we are really like him, and successful because, especially when an author is famous, and even when he isn't, "our" instinct (I criticize the practice and engage in it too) is to want to cooperate, to be included in the circle the author is drawing so cosily around "us." It is chummy, this "we." It feels good, for a little while, until it starts to feel coercive, until "we" are subscribing to things that "I" don't believe.

Tompkins, supra note 141, at 132.

185. Martha Minow comments that "[t]he critics often repeat in new contexts versions of the old assumptions they set out to contest." Elizabeth V. Spelman, Inessential Woman: Problems of EXClusion IN FEMINist Thought 57 (1988) (quoting Martha Minow).

186. In the contexts of racism and white feminism, which are equally applicable here, Adrienne

Rich discusses "white solipsism," which is

not the consciously held belief that one race is inherently superior to all others, but a tunnel-vision which simply does not see nonwhite experience or existence as precious or significant, unless in spasmodic, impotent guilt-reflexes, which have little or no long-term, continuing momentum or political usefulness.

Adrienne Rich, Disloyal to Civilization: Feminism, Racism, Gynephobia, in ON LIES, SECRETS, AND SILENCE 275, 306 (1979).

187. JAGGAR, supra note 176 , at 370 .

188. Bartlett, supra note 175 , at 872 .

189. SANDRA HARDING, THE SCIENCE QUestion IN FEMINISM 191 (1986).

190. See Mari J. Matsuda, Looking to the Bottom: Critical Legal Studies and Reparations, 22 
the viewpoint of the oppressed should be privileged.

One theorist argues that the standpoint of the oppressed is epistemologically advantageous for the following reasons:

It provides the basis for a view of reality that is more impartial than that of the ruling class and also more comprehensive. It is more impartial because it comes closer to representing the interests of society as a whole; whereas the standpoint of the ruling class reflects the imterests only of one section of the population, the standpoint of the oppressed represents the interests of the totality in that historical period. Moreover, whereas the condition of the oppressed groups is visible only dimly to the ruling class, the oppressed are able to see inore clearly the ruled as well as the rulers and the relation between thein. Thus, the standpoint of the oppressed includes and is able to explain the standpoint of the ruling class. ${ }^{191}$

But the claim that the standpoint of the oppressed is more impartial is unconvincing. It seems that the standpoint of the oppressed would be partial; it would not necessarily provide less distorted views but differently distorted views. The claim of representing society as a whole also seeins problematic because the viewpoints of the oppressed and oppressors are quite distinct and complex. ${ }^{192}$ It still might make sense to include the standpoint of the oppressed, however, not because it has any special access to the truth, but because what is taken as truth is incomplete or distorted without the views of the oppressed. ${ }^{193}$

There is the further problein of identifying the standpoint of the

HARV. C.R.-C.L. L. REv. 323, 324 (1987) ("Looking to the bottom-adopting the perspective of those who have seen and felt the falsity of the liberal promise-can assist critical scholars in the task of fathoming the phenomenology of law and defining the elements of justice.").

191. JAGGAR, supra note 176, at 370-71; see also Carey McWilliams, Introduction to CARLos Bulosan, America is in the Heart: A Personal History vii, xx-xxi (1973). McWilliams writes:

One of the best ways to view and understand a society is to see it from the bottom looking up .... [People at the bottom] see more ... than those who occupy the middle and upper reaches; their view is less inhibited, less circumscribed. The view from down under exposes the deceits, self-deceptions, distortions, apostasies; it is likely to be bitterly realistic. It offers a good, if limited, guide to what the society is really like, not what it professes to be.

Id. at $\mathrm{xx}$.

192. Cf. Charles R. Lawrence, III, The Word and the River: Pedagogy as Scholarship as Struggle, 65 S. CAL. L. REV. 2231, 2233 (1992). Professor Lawrence states:

The significance of fear must be understood from two points of view: that of the oppressor, or master, and that of the oppressed, or slave. Each of the perspectives must in turn be understood on several different levels of consciousness. The first is the fear of the slave. I begin here because it is the fear that is most apparent and because it is the fear that I know first hand-that I am experiencing at this moment.

Id. Thus, it is not enough for him to know the fcar of the slave; he must also understand the viewpoint of the master.

193. This is obviously a wcaker claim because one can no longer claim that the oppressed have a special access to truth that would necessitate inclusion of their perspective. Thus, exclusion of this perspective is not, by itself, enough of a reason to criticize an objective truth. 
oppressed. If oppression or subjugation provides the grounding for having a less distorted view, then it would seem that the prime candidate would be the standpoimt of lesbians of color. ${ }^{194}$ Even if, for the sake of simplicity, we decide that the relevant category is that of women, we are still left with the problem of identifymg this standpoint. One commentator warns that we cannot discover this standpoint "directly in women's naive and unreflective world view," 195 because this world view, usually labelled as false consciousness, has been shaped by the dominant male perspective so that it cannot be trusted. Even with standpoint epistemology, then, not all stories of oppression are created equal. This is problematic "because of the unwillingness, central to feminism, to dismiss some women as simply deluded while granting other women the ability to see the truth."196

The problem is further exacerbated because even if a standpoint of women is decided upon, and I will not ask by whom, this standpoint is open to the charge of gender essentialism, "the notion that a unitary, 'essential' women's experience can be isolated and described independently of race, class, sexual orientation, and other realities of experience."197 This charge of essentialism becomes even more damaging when it turns out that the "essential" women's experience silences the voices of women of color. ${ }^{198}$

I address these concerns because these same problems also plague the case for personal narrative. When we listen to personal narrative, we must ask two questions: whom is the narrator speaking as, and whom is she speaking for? For example, when I tell my stories, am I speaking as

194. It is clear that we could add other factors that would heighten oppression. By omitting a category such as physically challenged, I do not mean that such categories do not result in oppression. Sandra Harding discusses the internal logic of standpoint epistemologies that requires us to find the most oppressed group and then privilege that viewpoint. HARDING, supra note 189, at 191.

195. JAGGAR, supra note 176 , at 371 .

196. Catharine A. MacKinnon, Feminism, Marxism, Method, and the State: Toward Feminist Jurisprudence [1983], in FEMINIST LEGAL THEORY: READINGS IN LAW AND GENDER 181, 196 n.5 (Katharine T. Bartlett \& Rosanne Kennedy eds., 1991). While she notes the problem, she does not adequately resolve it. Mari Matsuda takes the position that false consciousness exists, but that by raising consciousness, critical consciousness, "the power of the subordinated to understand subordination and to derive means of liberation from it," can be achieved. Mari J. Matsuda, Pragmatism Modified and the False Consciousness Problem, 63 S. CAL. L. REv. 1763, 1778 (1990). She probably is right, but I am uncomfortable because she seems to repeat the "we know what's best for you" paradigm where those who have supposedly reached critical consciousness subordinate those who have not. Cf. Audre Lorde, The Master's Tools Will Never Dismantle the Master's House, in THIS BRIDGE CALLED MY BACK, supra note 80, at 98 (arguing that when those who have known oppression repeat oppressive patterns, a different, often equally negative hierarchy results).

197. Harris, supra note 13 , at 585 .

198. See $i d$. Elizabeth Spelman also addresses this problem in INESSENTIAL WoMAN: Problems of Exclusion in Feminist Thought (1988). She discusses the tendency of feminist theory to conflate "the condition of one group of women with the condition of all." Id. at 4. The problem, of course, is that the group usually taken for the whole is white middle-class women. 
an Asian American for all Asian Americans? ${ }^{199}$ If I claim this, then am I not privileging my voice to the exclusion of other voices? ${ }^{200}$ And if I do not speak for all Asian Americans, then what sort of normative conclusions can I draw from my narrative? Are my stories just stories?

I think that there are no satisfactory answers to these questions, at least no answers that provide a compelling justification for using personal narrative based on standpomt epistemology. Part of the difficulty comes from the level of abstraction one deals with when arguing withm the rational/empirical mode. This difficulty cannot be overcome unless these abstractions are put back into context. ${ }^{201}$

Ultimately, trymg to argue for narratives in the rational/empirical mode may lead one to become skeptical of the very premise of this mode-that an objective truth or knowledge is attainable. This issue has haunted philosophers since ancient times ${ }^{202}$ and the demand to know

199. This is similar to the typicality problem raised as a challenge against the use of personal narrative. See Abrams, supra note 159 , at 979-80.

200. The essentialist criticism would suggest, then, that the unitary Asian American experience was drawn from the perspective of a Korean American, heterosexual, professionally educated male. This perspective excludes the viewpoints of other Asian American groups, heterosexual Asian American women, Asian American gays and lesbians, Asian Americans with different educational backgrounds, and other Korean Americans not covered in the above categories. This may seem excessive, but I am trying to highlight the problems inherent in claims to representation. I am not being facetious when I admit that I cannot hope to reach the level achieved by Stanley Fish when he reveals his contextual embeddedness:

I am, among other things, white, male, a teacher, a literary critic, a student of interpretation, a member of a law faculty, a father, a son, an uncle, a husband (twice), a citizen, a (passionate) consumer, a member of the middle class, a Jew, the oldest of four children, a cousin, a brother, a brother-in-law, a son-in-law, a Democrat, short, balding, fifty, an easterner who has been a westerner and is now a southerner, a voter, a neighbor, an optimist, a department chairman.

Stanley Fish, Doing What Comes Naturally: Change, Rhetoric, and the Practice of THEORY IN LITERARY AND LEGAL STUDIES 30 (1989).

201. See Martha Minow \& Elizabeth V. Spelman, In Context, 63 S. CaL. L. Rev. 1597, 1601 (1990) (discussing the importance of context in revealing exclusion of groups from facially neutral statements).

202. For example, Plato was never quite able to articulate a complete theory of knowledge, although he did spend a fair amount of energy refuting Protagoras' relativism, which made man the determining factor of all experiences. Plato refutes this Protagorean doctrine, along with the Heraclitean doctrine of flux which held that the only thing that exists is change, in the Theaetetus, his longest sustained treatment of epistemology. Plato, Theaetetus, in ThE Collected Dialogues of Plato, supra note 172, at 845. Most commentators agree that the dialogue fails in that it does not arrive at a positive theory of knowledge. See, e.g., DAvid Bostock, Plato's THEAETETUS (1988).

Thus, the questions remain. What is objective knowledge? How can we objectively know that something is objective knowledge without already knowing what objective knowledge is? This circularity is implicit in most attempts by philosophers to get at knowledge.

Hegel also addresses this circularity in his critique of Kant's attempt to ascertain the possible conditions for knowledge:

What is demanded is thus the following: we should know the cognitive faculty before we

know. It is like wanting to swim before going in the water. The investigation of the faculty of knowledge is itself knowledge, and cannot arrive at its goal because it is this goal already. 
knowledge creates problems for those having faith in objective knowledge. It can lead ultimately to philosophical skepticism, ${ }^{203}$ or it can lead to a different kind of epistemology, one without foundations.

\section{Post-Structuralism and the Narrative Turn}

Post-structuralism relies on a conception of language and knowledge that is not based on any universalist theoretical ground. ${ }^{204}$ In other words, post-structuralisn is anti-foundational. Stanley Fish writes:

Anti-foundationahism teaches that questions of fact, truth, correctness, validity, and clarity can neither be posed nor answered in reference to sone extracontextual, ahistorical, nonsituational reality, or rule, or law, or value; rather, anti-foundationalism asserts, all of these nratters are intelligible and debatable only within the precincts of the contexts or situations or paradigms or communities that give them their local and changeable sliape. ${ }^{205}$

From this, it might seem that anti-foundationalism is nihilistic; however, it is quite the opposite in that it provides for certainty, but only within the local, partisan point of view, which is posited as the only available point of view. And as one commentator notes, "[k]nowing that my knowledge is perspectival, language-based, culturally constructed, or what have you, does not change in the slightest the things I believe to be

Jürgen Habermas, KNowledge ANd Human INTERESTS 7 (1968) (quoting Hegel, Vorlesungen über die Geschichte der Philosophie).

203. For example, Thomas Nagel argues:

Objectivity itself leads to the recognition that its own capacities are probably limited, since in us it is a human faculty and we are conspicuously finite beings. The radical form of this recognition is philosophical skepticism, in which the objective standpoint undermines itself .... Skepticism is radical doubt about the possibility of reaching any kind of knowledge, freedom, or ethical truth, given our containment in the world and the impossibility of creating ourselves from scratch.

Thomas NAGel, The View From Nowhere 7 (1986).

It is important to note that " $[t]$ he skeptic does not deny that what is described as knowledge is in fact knowledge. Rather, the skeptic denies that we ever have knowledge." Patterson, supra note 175 , at 265 . Thus, one can be a skeptic and still believe in objective linowledge. Thomas Nagel takes this position when he says that even though objectivity is impossible to attain, we should nevertheless still try to achieve it. His method is to "think of reality as a set of concentric spheres, progressively revealed as we detach gradually from the contingencies of the self." NAGEL, supra at 5. However, it is impossible to achieve an abstraction from the self that brings one to "the view from nowhere." Cf. FISH, supra note 200, at 436-67 (criticizing what he calls critical self-consciousness, the notion that the self can exist apart from its connections to the world).

204. See Deborah L. Rhode, Feminist Critical Theories, 42 Stan. L. Rev. 617, 620 n.8 (1990) ("Post-structuralism, which arises from and contributes to this post-modern tradition, refers to theories of interpretation that view meaning as a cultural construction mediated by arrangements of language or symbolic form. What distinguishes post-structuralism from other interpretive schools is the premise that these arrangements are unstable and contradictory, and that readers ereate rather than simply discover meaning."). I set forth this position, but I do not discuss in detail the poststructuralist critique of objectivity. For examples of this critique, see Michel FouCAULT, THE ARCHAEOLOGY OF KNOWLEDGE (A.M. Sheridan Smith trans., 1972); RICHARD RORTY, PHILOSOPHY AND THE MIRROR OF NATURe (1979).

205. Fish, supra note 200 , at 344. 
true."206

Many people, though, find it disturbing that there are no external, overarching systems of legitimation. ${ }^{207}$ They want to be able to say that all Nazis are bad, all of the time. They are concerned that if Professor Fish's anti-foundationalism is correct, then they will not be able to pass judgment on Nazis, that they will not be able to engage in ineaningful social criticism. Professor Fish responds that anti-foundationalism does not prevent value judgments; it only allows value judgments to be made and have ineaning in certain contexts. Thus, to try to inake a universal, alistorical claim about all Nazis being bad is ineaningless because the phrase "All Nazis are bad" has ineaning only in certain contexts. ${ }^{208}$ The inplication of anti-foundationalisin for the practice of social criticism is that it cannot provide a coinpelling "ought" in the rigorous sense of the word. ${ }^{209}$ But then "ought" has been on shaky ground ever since David Hume said, "Tis not contrary to reason to prefer the destruction of the whole world to the scratching of my finger."210 Yet life went on-morality was not destroyed, ${ }^{211}$ and anarchy did not ensue.

The fear is that if we go down the post-modern road, we will no longer be able to practice social criticism in a coinpelhing way, because without objectivity, Asian Americans and other diseinpowered groups cannot claim that our emergence from subordination "is less artificial

206. Tompkins, supra note 141 , at 125.

207. See Nancy Fraser \& Linda J. Nicholson, Social Criticism without Philosophy: An Encounter between Feminism and Postmodernism, in FEMINISM/PosTMODERnISM, supra note 134, at 19, $21-26$ (discussing and critiquing the work of post-modernist Jean-François Lyotard).

208. Stanley Fish, Lecture on Legal Theory, Duke Law School (Fall 1991).

209. A compelling "ought" is one that is morally and unconditionally imperative, in the sense of a Kantian categorical imperative. See IMMANUEL KANT, Foundations OF THE METAPHYSICS OF Morals \& What Is ENLlghtenment? 30 (Lewis W. Beck trans., rev. 2d ed. 1990) ("The categorical imperative would be one which presented an action as of itself objectively necessary, without regard to any other end.").

210. David Hume, A TREatise of Human Nature bk. 3, pt. 2, sec. 3, at 416 (L.A. SelbyBigge \& P.H. Nidditch eds., 1978). Immanuel Kant even said of the question "What ought I to do?," that "[s]o far, then, as knowledge is concerned, this much, at least, is certain and definitively established, that in respect of [that question], knowledge is unattainable by us." IMMANUEL KANT, CRITIQUe of PuRe REASON 635 (Norman K. Smith trans., 1929).

211. One commentator describes Hume's account of morality as the outcome of a search for ways of eliminating contradictions in the "passions" of sympathetic persons who are aware both of their own and their fellows' desires and needs, including emotional needs. Any moral progress or development a person undergoes will be, for Hume, a matter of "the correction of sentiment," where what corrects it will be contrary sentiments, plus the cognitive-cum-passionate drive to minimize conflict both between and within persons... . But "the ultimate ends of human actions can never, in any case, be accounted for by reason, but recommend themselves entirely to the sentiments and affections of mankind, without any dependence upon intellectual faculties."

Annette C. Baier, Hume, the Women's Moral Theorist?, in WoMEN AND MORAL TheORY 37, 41 (Eva F. Kittay \& Diana T. Meyers eds., 1987) (quoting David HumE, Enquiries: Concerning Human Understanding and Concerning the Principles of Morals 293 (L.A. Selby-Bigge \& P.H. Nidditch eds., 1975) (1777)). 
and constructed than that which [we] have cast off."212 This conclusion seems to be the ultimate logic of the post-structuralist critique. However, this conclusion is not as devastating as it first might seem. It does not render political action impossible; if anything, it does the opposite, in the sense that political action is all that will be left. The post-structuralist critique changes the present game, which involves the search for legitimation, by eliminatimg the possibility of any appeal to an external standard for legitimation. It becomes, as if it were ever anything but, a question of power, where no one can claim a superior legitimacy nor deny the legitimacy of another's viewpoint or story. ${ }^{213}$

Narratives, then, cannot be discounted because in this game of power there is no "objective" standard for disqualification; one "wins" by being more persuasive. Narratives, especially narratives about personal oppression, are particularly well-suited for persuasive purposes because they can provide compelling accounts of how things are in society. ${ }^{214}$ These stories will carry considerable persuasive power because in our present political-legal chmate, which is dommated by liberal political pliilosoplyy, oppression is undesirable. ${ }^{215}$ This is the space within which Asian American Legal Scholarship will use narrative.

\section{III \\ The Asian American EXPERIENCE: A NARrative ACCOUNT $^{216}$ OF EXCLUSION AND Marginalization}

Exclusion has many faces. Its harms are insidious and its methods multifarious. One reason that exclusion is so readily able to work its harms is that exclusion, at a certain point, becomes so pervasive that it

212. Bartlett, supra note 175 , at 879 . She makes this comment referring to feminists, but her statement can be generalized. One further concern is the fear that the post-structuralist critique deconstructs the category "Asian American" in such a way as to render it meaningless. This is a misunderstanding of the post-structuralist critique. See infra Part IV.C.

213. See generally Michel Foucault, POWER/KNOWLEdge: SElected INTERVIEWS AND OTHER Writings, 1972-1977 (Colin Gordon ed. \& Colin Gordon et al. trans., 1980).

214. Litigators have long recognized the potentially strong, persuasive power of narratives. See Jane B. Baron, The Many Promises of Storytelling in the Law, 23 RuTGERs L.J. 79, 97 (1991) (book review) ("Litigators have long known that trying cases involves telling stories, and there is a welldeveloped literature on trial advocacy that emphasizes storytelling skills.").

See infra Part III for examples of how narratives have helped bring about social change.

215. See Matsuda, supra note 196, at 1768 (recommending "rectification of past injustice and elimination of all present forms of subordination" because "[t]he emphasis on context and provisional truth does not remove the obligation to divide right from wrong and to retain justice as the goal of theory").

I realize that I have not quite solved the credibility problem, see supra Part II.B, but it may be as Robin West says: "We need to flood the market with our own stories until we get [the] point across." Patricia Meisol, A New Genre of Legal Scholarship: Storytelling Feminist Takes on the Fundamentals of Law, L.A. TIMES, Oct. 7, 1988, § 5, at 8 (quoting Robin West).

216. By narrative account, I mean not only the personal narratives of individuals but also the stories of entire communities, which texture the factual history with life and emotional depth. 
becomes invisible. ${ }^{217}$ In this way, the present-day effects of exclusion become disconnected from the past. As a consequence, the oppressed are blamed for the sins of their oppressors. For example, the dominant group often condemns the existence of ethnic enclaves such as Chinatowns and decries the unassimilability of Asian Americans. In doing so, the dominant group forgets that their laws and their history helped to create these ghettos. ${ }^{218}$ In this way, the past is obscured, ${ }^{219}$ and the victim is blamed, or worse, forgotten. But since "[i]nvisibility is not a natural state for anyone,"

In Part I, I examined two mformal mechamisms of oppression, nativist-inspired violence and discrimination ${ }^{221}$ and the racial hierarchy remforced by the model minority myth, ${ }^{222}$ to show the need for a distinct Asian American Legal Scholarship to fully address such issues. The general public views occurrences of anti-Asian violence "as "isolated incidents' with no comınon underlying cause"223 and believes Asian

217. Charles Lawrence makes this same claim but more specifically about racism. Lawrence, supra note 75, at 330 ("Racism's universality renders it normal."). Catharine MacKinnon makes a similar claim: "To the extent poruography succeeds in constructing social reality, it becomes invisible as harm." MACKINNON, supra note 165, at 204.

218. See Su Sun Bai, Comment, Affirmative Pursuit of Political Equality for Asian Pacific Americans: Reclaiming the Voting Rights Act, 139 U. PA. L. REV. 731, 743 (1991). As for Chinatowns being ghettos, the poet Nellie Wong writes:

when I was growing up, I swore

I would run away to purple mountains,

houses by the sea with nothing over

my head, with space to breathe,

uncongested with yellow people in an area

called Chinatown, in an area I later learned

was a ghetto, one of many hearts

of Asian America

Nellie Wong, When I Was Growing $U_{p}$, in TH1S BRIDGE CALLED MY BACK, supra note 80, at 7, 8.

219. It may be more appropriate to say that history is destroyed rather than merely obscured.

Cf. Steve Biko, White Racism and Black Consciousness, in I WRTte What I Like 61, 69 (Aelred Stubbs ed., 1978) ("As Fanon puts it: 'Colonialism is not satisfied merely with holding a people in its grip and emptying the Native's brain of all form and content; by a kind of perveted [sic] logic, it turns to the past of the oppressed people and distorts, disfigures, and destroys it.' At the end of it all, the blacks have nothing to lean on, nothing to cheer them up at the present moment and very much to be afraid of in the future.").

Similarly, much of the history of Asian Americans has been distorted or omitted in United States history textbooks. See RACISM ANd SExISM RESOURCE CTR. FOR EduCATors, supra note 25, at 34 ("Textbooks, for the most part, omit this history of Asian Americans-their role as workers in a wide variety of occupations; the institutionalized oppression, economic exploitation and anti-Asian violence they faccd; their long history of resistance and struggle; and the present-day problems that confront them.").

220. Yamada, supra note 80 , at 40 . Professor Yamada also comments:

I would like to think that my new awareness is going to make me more visible than ever, and to allow me to make some changes in the "man made disaster" I live in at the present time. Part of being visible is refusing to separate the actors from their actions, and Id. demanding that they be responsible for them.

221. See supra Section I.A.

222. See supra Section I.B.

223. George Kagiwada, The Killing of Thong Hy Huynh: Implications of a Rashomon 
Americans to be successful and therefore not victims of discrimination. ${ }^{224}$ To counter this dommant mindset and make visible the problems of Asian Americans, I offer differing accounts, or what Professor Delgado calls "counterstories."225

I tell counterstories in this Part to show how narratives perform three related and overlapping functions. Narratives can perform the following functions: (1) reveal the real-life effects that discriminatory laws and governinental neglect have on individuals' psyches and Asian American cominunities' development, (2) counter the popular notion of Asian Americans as apolitical, and (3) effectively challenge unjust laws and correct past injustices. These functions of narrative are especially important for Asian American Legal Scholarship, since the model ninority niyth and the erroneous belief that Asian Americans do not face discrimination cloud and mask the oppression of Asian Aniericans. We must tell our stories and our history again in order to shatter the myth and other mistaken beliefs about Asian America. Only then can we bring about social change. If social and political change is ultimately a game of power and persuasion, ${ }^{226}$ then narratives provide both an insight into everyday realities and a moral "punch" to justify and bring about change.

In this Part, I will exanine iniportant areas of Asian American history and experience where narratives have or could perform one or more of the functions enumerated above. This Part is neither a comprehensive nor a definitive history. It is not intended to argue solutions. Rather, this Part brings to view monients in Asian American history when our stories of formal and informal injustice have been most poignant, and therefore potentially nost effective in bringing about change.

I proceed chronologically, by first examining the immigration, naturalization, and voting rights laws, which, as formal expressions of nativistic racism, have prevented Asian Americans from participating fully in law and politics. Second, I will exanine one of the seminal events in Asian American history, the Japanese Anrerican internment during World War II and the subsequent Redress and Reparations Movement, which succeeded primarily because of the personal stories of fornier internees. Third, I will give the conteniporary narrative of Asian immigrant garment workers, an Asian Ainerican group which does not fit the model ninority stereotype, in order to show that the inyth is false amidst the tremendous diversity of Asian America and to suggest that such nar-

Perspective, in Frontiers of Asian American Studies 253, 253 (Gail M. Nomura et al. eds., 1989).

224. See supra note 11 .

225. Delgado, supra note 137 , at 2414 ("[S]tories build consensus, a common culture of shared understandings, and deeper, more vital ethics. Counterstories, which challenge the received wisdom, do that as well.").

226. See supra note 213 and accompanying text. 
ratives can be used to bring about social and legal change for these groups. Indeed, the many socioeconomic, cultural, and historical differences among Asian American groups make it even more imperative that Asian American issues and history are given a special voice and forum. Ultimately, however, despite these differences, all Asian Americans share certain common experiences which connect and unify us.

What follows, then, is a story of the past. It is also a story of the present. I tell it now because I do not want it to be a story of the future.

\section{A. Exclusion from Legal and Political Participation}

\section{Immigration and Naturalization}

America has power, but not justice.

In prison, we were victimized as if we were guilty.

Given no opportunity to explain, it was really brutal.

$I$ bow my head in reflection but there is nothing I can do. ${ }^{227}$

This poem was written by an anonymous Chinese immigrant detained on Angel Island im San Francisco Bay. ${ }^{228}$ In the first half of the twentieth century, all Chinese immigrants were detained as suspects until their claims for right of entry were verified by intensive cross-examination. ${ }^{29}$ The feeling of powerlessness this poet ${ }^{230}$ describes reflects the culmination of discriminatory policies that began soon after the Chinese first arrived in America. ${ }^{231}$ Individual and commumity stories from this

227. Anonymous, Untitled, in IsLAND: POETRY AND HISTORY of ChINESE IMMIGRANTS ON ANGEL IsLAND, 1910-1940, at 58 (Him Mark Lai et al. eds., 1980) [hereinafter IsLAND]. This poem was discovered on the walls of the Angel Island barracks, along with over 135 other poems written by Chinese immigrants awaiting either permission to enter the United States or orders for deportation from America. Id. at 23. The poems were translated by the editors whose parents were Angel Island inmates. Id. at 8. "The ordeal of immigration and detention left an indelible mark in the minds of many Chinese, a number of whom wrote poetry on the barrack walls, recording the impressions of their voyage to America, their longing for families back home, and their outrage and humiliation at the treatment America accorded them." Id.

228. Id. at 23,58 .

229. Id. at 12. Often the same question would be addressed separately to the applicant and witnesses. Discrepancies could endanger the application. One former detainee recalls:

Sometimes the interrogator would try to trip you, like I told him the village's altar of worship was on the east side of the village. At the next session, he said my papa said it was on the west side. But I still said east side, and they all laughed.

Id. at 117 (editors' interviewing Mr. Wong, who was 12 when he was detained on Angel Island in 1933).

An unfavorable decision could be appealed, but the process took a long time, and some immigrants were detained on the island for as long as two years awaiting final disposition of their cases. See id. at 22.

230. None of the poems which survived were written by women. Id. at 25 . Whatever poems, if any, that may have been written by women were lost when a fire destroyed the women's quarters. Id. at 25-27.

231. The Chinese were the first Asian immigrants to enter the United States in significant numbers. CIVIL RIGHTS REPORT, supra note 7, at 2. I use the term "immigrant" even though many historians refer to all the early Chinese as sojourners who intended to return to China rather than as immigrants who intended to settle in the United States. See CHAN, supra note 53, at $\mathrm{xx}$ 
period resonate with degradation and despair. But the early history of Asian immigrants is also marked by their determined struggle against anti-Asian discrimination.

Knowledge of the experience of the early Chinese immigrants provides a context for understanding the experiences of all Asian inminigrant groups because other Asian immigrants encountered similar violence and discrimination when they arrived. ${ }^{232}$ Later arrivals, trying to avoid this discrimination, distanced themselves from earlier arrivals. For exainple, im an attempt to distinguish theinselves from the Chinese, Japanese inen wore Western-style suits when they arrived in the United States, and Japanese "picture brides who arrived wearing kimonos and wooden clogs were whisked off upon landing by their husbands to dressmakers and shoemakers to be outfitted with Victorian clothing and shoes."233 The Koreans "thought that the Chinese and Japanese inmigrants before them had provoked white anti-Asian reactions by retaining their old ways and keeping to themselves."234 They tried to overcone racial discrimination by distancing themselves froin the Chinese and Japanese and by becolming inore "westernized."235 Asian Indians were distinguished from other Asians by European and North American scholars, who identified Asian Indians as descendants of the Aryan (white) race; many Asian Indian immigrants embraced this myth. ${ }^{236}$ Filipinos distanced themselves from the Chinese by identifying themselves with the Malay

(arguing that neither term is completely correct but that "[t]o insist that all Chinese who came to America were sojourners-as some scholars have done-is to exclude them categorically from American immigration history"). Further, this notion of the Chinese as solely sojourners perpetuates certain misperceptions:

The Chinese, so the argument goes, unlike all other immigrant groups, did not come to this country with a desire to settle and assimiliate, but rather with the intention to make a quick fortune and return home. It was this feature of their immigration, according to this view, that was most responsible for the misfortunes that were visited upon them. White Californians had offered the hand of welcome to the newcomers from Asia but were rebuffed because these immigrants had no interest in staying or being acculturated. Having made overtures of goodwill and having seen them ungenerously rejected by the ethnocentric Chinese, the white majority population then turned on the Chinese and determined to exclude them "from the privileges and obligations of other immigrants" ....

A very important corollary of the sojourner theme is the notion that the nineteenth century Chinese community had utterly no interest in American political institutions or desire to adapt itself to them.

Charles J. McClain, Jr., The Chinese Struggle for Civil Rights in Nineteenth Century America: The First Phase, 1850-1870, 72 CALIF. L. REv. 529, 532-33 (1984) (footnotes omitted) (quoting Gunther Barth, BitTer Strength: A History of THE Chinese in THE UNITED States, $1850-1870$, at $I$ (1964)). These misperceptions are themes that I return to throughout this Part.

232. See, e.g., TAKAKI, supra note 1 , at 181 (noting that Japanese immigrants "inherited much of the resentment and prejudice that had been directed against the Chinese").

233. CHAN, supra note 23 , at 46.

234. TAKAKI, supra note 1 , at 277.

235. Id.

236. See Sucheta Mazumdar, Race and Racism: South Asians in the United States, in Frontiers of ASIAN AMERICAN StUdies, supra note 223, at 25, 26-30 (footnote in title omitted) (discussing the origins of the "Aryan Theory of Indian History"). 
rather than the Mongohian race. ${ }^{237}$ In essence, the discriminatory laws against the Chinese not only hurt the Chinese immigrants but, by encouraging each group to be more "western" than the next, also prevented the building of coalitions among different Asian American groups. Ironically, despite these efforts by Japanese, Korean, Asian Indian, and Filipino immigrants to "westernize" and to be accepted, they were treated by white Americans as merely different strams of the same "Yellow Peril" first einbodied by the Chinese. ${ }^{238}$

The Chinese, along with thousands of other pioneers, were drawn to California by the Gold Rush, with 325 Chinese arriving in 1849,450 in 1850,2176 in 1851, and 20,026 in $1852 .{ }^{239}$ They were not long in America before they began encountering legal and political opposition. ${ }^{240}$ For exainple, in 1854, the California Supreine Court ruled that Chinese immigrants could not testify agamst a white person in a court of law. ${ }^{241}$ This prohibition profoundly limited the chances for the Chinese, the vast

237. See TAKAKI, supra note 1 , at 330 (discussing a successful challenge by a Filipino of California's antimiscegenation law forbidding marriages between whites and "Negroes, mulattoes, or Mongolians" but not Malays; the victory was short-lived, because the California legislature almost immediately added the Malay race to the antimiscegenation laws).

238. See id. at 192, 272, 297, 324.

239. Id. at 79. Chinese settled in Hawaii as early as 1802 and there were several Chinese sugar companies by the 1830 s, although the first sizable group of Chinese arrived in 1852 . CHAN, supra note 23 , at 26.

Generally, I discuss immigration of Asians to the Hawainan territories only in the context of further immigration to the mainland. For a discussion of Asian immigrants in Hawaii, see TAKAK1, supra note 1, at 132-76 (discussing Chinese, Japanese, Korean, and Filipino laborers on Hawaiian plantations).

240. Discriminatory taxes were an early tactic used by the California legislature to discriminate against the Chinese and to discourage further immigration. For a discussion of these taxes and the reactions of the Chinese, see McClain, supra note 231, at 539-48. For a discussion of anti-Chinese legislation in California, see McGovney, supra note 69, at 54-59.

241. People v. Hall, $4 \mathrm{Cal}$. 399 (1854). At the trial court level, the jury heard testimony from three Chinese and one Caucasian and found George Hall guilty of the murder of Ling Sing. The California Supreme Court reversed the conviction, holding that the Chinese testimony was improperly admitted. Id. at 405 . In reaching this result, the court determined that a statute preventing "Blacks," "Mulattos," and "Indians" from testifying against "Whites" also applied to the Chinese, in order to protect whites from the testimony of all nonwhites. Id. at 403 . In 1863, the California Legislature codified the exclusion of Chinese testimony from both civil and criminal cases. Chan, supra note 23, at 48. Note that even after the California Penal and Civil Procedure Codes dropped this ban on testimony by the Chinese, "evidence offered by Chinese was virtually never accepted except in cases involving other Chinese." Id. (citing Hudson N. Janisch, The Chinese, the Courts, and the Constitution: A Study of the Legal Issues Raised by Chinese Immigration to the United States, 1850-1902, at 227 (1971) (unpublished J.D. dissertation, University of Chicago)).

This prohibition of Chinese testimony against a white person was briefly extended to prohibit Chinese testimony against blacks born in the United States. See People v. Washington, $36 \mathrm{Cal} .658$ (1869) (implying in dicta that the ban on Chinese testimony might violate the California Constitution or the Fourteenth Amendment), overruled by People v. Brady, 40 Cal. 198 (1870) (overruling the dicta in Washington and holding explicitly that the ban on Chinese testimony did not violate either the United States or the California Constitution).

It was not until the Civil Rights Act of 1870 that all persons were granted the right to give evidence, although implementation of the Act's provisions were slow. McClain, supra note 231, at 56-67. 
majority of whom hived in California at this time, ${ }^{242}$ to obtain justice. ${ }^{243}$

While this prohibition from testifying in California's state courts presented a great barrier to full participation in the American politicallegal process, the greatest formal obstacle was the 1790 federal naturalization statute that permitted only "free white persons" to become naturalized. ${ }^{244}$ Following the Fourteenth Amendment and the subsequent amendment of the naturalization statute to include persons of African nativity or descent, ${ }^{245}$ Asians became the only group of aliens ineligible for citizenship. ${ }^{246}$ An 1878 decision by a circuit court in California solidified this bar against naturalization of Chinese aliens. ${ }^{247}$ From that point, the Chinese were generally ineligible for naturalization. ${ }^{248}$ Opinion was divided with regard to the Japanese and Asian Indians, a few of whom had managed to become naturatized, ${ }^{249}$ but the United States Supreme Court eventually decided that "white persons" under the naturalization statutes did not include the Japanese ${ }^{250}$ and Asian Indian immigrants. ${ }^{251}$

The decision denying Asian Indians the right to naturalize nullified the citizenship of scores of Asian Indians granted before the decision. ${ }^{252}$

242. CHAN, supra note 23, at 48 .

243. Even before Hall,

Chinese leaders as early as $\mathbf{1 8 5 3}$ had complained to the legislature about the exclusion of testimony from Chinese witnesses in certain state courts. Concern heightened as the number of crimes committed against Chinese in the mining districts increased and as the conviction deepened that potential perpetrators were being emboldened by the good chance that their victims would be forever unable to testify against them.

McClain, supra note 231, at 548 (footnote omitted).

244. U.S. COMM'N ON CIVIL Rights, THE TARNished Golden DoOR: CIVIL Rights Issues IN IMMIGRATION 10 n.38 (1980) [hereinafter THE TARNISHEd GoldEN DooR].

245. CIVIL Rights REPORT, supra note 7 at 2.

246. When the naturalization statute was amended to include persons of African nativity or descent, Senator Charles Sumner of Massachusetts introduced a bill to make the naturalization statutes color-blind. DaNiELs, supra note 55, at 43 . It was defeated 30-14. Id. at 43 n.31. A later effort by Senator Lyman Trumbull of Illinois to include persons born in China also failed, by a margin of 31-9. Id.

247. In re Ah Yup, 1 F. Cas. 223 (C.C.D. Cal. 1878). Prior to this decision, local courts, which heard naturalization petitions, had inconsistently applied the naturalization statute. For example,

Fifteen Chinese in New York gained citizenship in $1878 \ldots$ and the newspaper reporter who interviewed them noted that one of their friends had become a citizen as early as 1873 and had "served as a juryman ... the first Chinaman who ever acted in the capaeity in Europe or America."

CHAN, supra note 23, at 47 (alteration in original). An even earlier example is Yung Wing, who became a naturalized United States citizen on October 30, 1852. DANIELS, AsIAN AMERICA, supra note 55 , at $26-27$.

248. See Civil Rights RePoRT, supra note 7, at 2.

249. Compare In re Sadar Bhagwab Singh, 246 F. 496, 500 (E.D. Pa. 1917) (holding that Hindus are not eligible for naturalization) with In re Mohan Singh, 257 F. 209 (S.D. Cal. 1919) (holding that any Hindu is a white person and thus eligible for naturalization).

250. Ozawa v. United States, 260 U.S. 178 (1922).

251. See United States v. Thind, 261 U.S. 204 (1923).

252. See Mazumdar, supra note 236, at 30 ("By September 1926, forty-three South Asians had had their citizenship annulled while the others were to battle in the courts for years to come."). 
For at least one person, loss of citizenship was tantamount to loss of personhood. His suicide note, in which he claimed he had tried to be "as American as possible,"253 said:

But now they come to me and say, I am no longer an American citizen. . . . What have I made of myself and my children? We cannot exercise our rights, we cannot leave this country. ... I do not choose to live a life of an interned person. ... Obstacles this way, blockades that way, and the bridges burnt behind."254

Improvements in these discriminatory naturalization statutes began during the $1940 \mathrm{~s}^{255}$ and culminated with the McCarran-Walter Act of $1952 .{ }^{256}$

Besides denying Asians rights generally thought to accompany citizenship, classifying aliens into two groups-those eligible and tliose ineligible for citizenship-provided the basis for state discrimination. ${ }^{257}$ In essence, such classification permitted states to pass statutes that were race-neutral on their faces, and thus immune to equal protection cliallenges, whicl nevertheless discriminated on the basis of race. ${ }^{258}$ Many states took advantage of this classification to outlaw ownership of land by aliens ineligible for citizenship. ${ }^{259}$ States also enacted licensing laws that prevented Asian immigrants, as aliens inehgible for citizenship, from becoming "attorneys, plyysicians, teachers, pharmacists, veterinarians, hairdressers, cosmetologists, barbers, funeral directors, peddlers, and hunters." 260 In certain parts of the country, children of Asian nativity or Asian ancestry were placed in segregated schools. ${ }^{261}$ Asian Americans

253. TAKAKI, supra note 1, at 299.

254. Id. at 300 .

255. See id. at 378 (noting that Chinese were given right of naturalization in 1943 and granted an annual quota of 105 immigrants); id. at 417 (noting that Filipinos were given right of naturalization in 1946 and provided with an annual quota of 100 immigrants); Mazumdar, supra note 236, at 30-31 (noting that South Asians were given right of naturalization in 1946 and when India and Pakistan became independent countries in 1947, a quota of 100 was set for each). A bill to permit Korean immigration and naturalization was introduced in Congress in 1944 but did not pass.

TAKAKI, supra note 1 , at 367 .

256. 8 U.S.C. $\$ 1101$ (1988).

257. See McGovney, supra note 69, at 7-11.

258. See Terrace v. Thompson, 263 U.S. 197 (1923) (rejecting an equal protection challenge to a Washington land law which denied Asians, as aliens ineligible for citizenship, the right to own and lease land); see also McGovney, supra note 69, at 34-54 (criticizing the decision of the United States Supreme Court in upholding the validity of a California law which denied aliens ineligible for citizenship the rights to acquire interest in real property, to farm land under a crop-sharing agreement, and to hold stock in a corporation authorized to hold real property).

259. See McGovney, supra note 69 , at 7-8 (listing 10 states with laws preventing aliens ineligible for citizenship from acquiring interest in or owning land; one state, Arkansas, specifically prohibited ownership of land by any Japanese or person of Japanese descent). These laws remained in effect until Asian immigrants were granted naturalization rights. See infra notes 284-86 and accompanying text.

260. Bai, supra note 218 , at 751 n.95.

261. See Westminster School Dist. v. Mendez, 161 F.2d 774, 780 (9th Cir. 1947) (discussing CAL. Educ. CODE $\S 8003-4$, which required the segregation of Chinese, Japanese, or Mongolian 
were thus denied quintessential American rights, such as the right to own property, the right to choose one's profession, and the right to send one's children to public schools.

Yet even through the hard times recounted above, Asian Ainericans did not passively accept these and other injustices. ${ }^{262}$ Most people know about Brown v. Board of Education ${ }^{263}$ and the cases leading up to it, in which African Americans cliallenged segregated scliool systeins, but few people know that Asian Americans also cliallenged the legality of segregated schools. Chinese plaintiffs filed lawsuits claallenging segregated schools as violative of their equal protection rights. ${ }^{264}$ Japanese immigrants pursued a political solution to the problein of segregated schooling. ${ }^{265}$ Althougl such measures ultimately proved unsuccessful, I mention them now to counter the charge that Asian Americans lave not faced discrimination and to cliallenge the inyth that Asian Americans are a passive model minority.

Asian American contributions to the civil rights moveinent have been largely ignored and are often actively denied. ${ }^{266}$ Even significant

children); see also CHAN, supra note 23, at 57-59 (discussing segregated schools for Chinese children, foreign-born and American-born, in California and Mississippi, and for Japanese children in San Francisco). Before World War II, there were relatively few Korean and Filipino children, and little research has been conducted about their status, although in 1905 Korean students were ordered by the San Francisco Board of Education to transfer to the "Oriental School" serving Chinese children. Id. at 59. As for Asian Indians, virtually no Asian Indian women immigrated to the United States before World War II; thus, there were few Asian Indian children here. Id.

262. One interesting example is a bilingual English-Chinese phrase book printed by Wells, Fargo in 1875 and expanded in 1877. See Wong Sam and Assistants, An English-Chinese Phrase Book, in The Big AllieEeeE!: AN ANThology of Chinese AMerican and Japanese AMERICAN LITERATURE 93 (Jeffery P. Chan et al. eds., 1991). The first edition was distributed to Wells, Fargo's 130 offices throughout the West in towns where Chinese immigrants lived and worked. The larger edition was distributed in more than 200 towns with Chinese American populations. Id. at 93 . The phrase book includes such phrases as "They are going to extort a confession from him by false pretensions," "I bailed him out of jail," "No doubt the judge will convict him," "You have violated the Constitution of this State," and "The immigration will soon be stopped." Id. at $94-110$. These are just a few of the many law-related phrases, but they indicate "Wong Sam and Assistants' tactics and strategy for dealing with the white man's application of the law do not include submission, acculturation, and assimilation." $I d$. at 93.

263. 347 U.S. 483 (1954).

264. See Gong Lum v. Rice, 275 U.S. 78, $82-87$ (1927) (holding that when no public schools for "Mongolians" existed, Chinese children may attend "colored public schools" but not "white public schools," and this would not violate the Fourteenth Amendment); Wong Him v. Callahan, 119 F. 381 (C.C.N.D. Cal. 1902) (holding that segregated schools did not deprive Chinese students of equal protection under the laws of California). The Court in Gong Lum noted that although most of the cases it relied upon to deny the equal protection challenge "arose . . over the establishment of separate schools as between white pupils and black pupils,... we can not think that the question is any different, or that any different result can be reached... where the issue is as between white pupils and the pupils of the yellow races." Id. at 87.

265. See CHAN, supra note 23, at 59 (discussing how Japanese children in San Francisco were allowed to leave the "Oriental School" and to attend white schools after a political compromise was reached between Japan and the United States).

266. One commentator blames this on the failure of American historiography to take into account Chinese perspectives, focusing instead on reactions of the white populace. McClain, supra 
contributions to civil rights have been forgotten. For example, few people know that the Chinese played an important role in the enactment of Reconstruction-era civil rights legislation. Section 1981 of title 42 of the U.S. Code, a major tool in civil rights hitigation, derives not from Section 1 of the Civil Rights Act of 1866, but from Section 16 of the Civil Rights Act of $1870,{ }^{267}$ "a statute that was not designed-at least not in any primary sense-to proinote the civil rights of the nation's newly emancipated black citizens, but rather to respond to the plight of another aggrieved racial minority-the Chinese of California."268 Section 16 of the 1870 Civil Rights Act was enacted because of successful lobbying efforts by leaders of the Chinese immigrant community. ${ }^{269}$ While the language of Section 16 is similar to that of Section 1 of the 1866 Act, one key difference exists: Section 16 went further in extending civil rights to all persons and not just to citizens. ${ }^{270}$ Section 16 of the 1870 Civil Rights Act and the Fourteenth Amendment became important tools for Chinese immigrants in their efforts to secure civil rights. Test cases brought after the passage of the 1870 Act by the Chinese did remarkably well in challenging discriminatory state and local measures. ${ }^{271}$

However, the Chinese community was unable to effectively challenge the federal government's anti-Chinese ineasures. ${ }^{272}$ These federal measures ultimately had a profound impact on the psyche and develop-

note 231, at 531-32. One result of excluding the Chinese perspective is the continued emphasis by mainstream scholars on the insularity and political isolation of the Chinese. Id. at 533. Other Asian groups have also been excluded by historians. TAKAk1, supra note 1, at 7. As a result, "[w]e need to 're-vision' history to include Asians in the history of America, and to do so in a broad and comparative way." Id.

267. McClain, supra note 231, at 529-31 (citing Runyon v. McCrary, 427 U.S. 160 (1976)). In Runyon, the court analyzes whether 42 U.S.C. $\S 1981$ reached discriminatory behavior by private, nongovernmental institutions, and Justice Stewart, writing for the majority, made this error. Runyon, 427 U.S. at 168-70. Justice White, joined by Justice Rehnquist, got it right. Id. at 195-205.

268. McClain, supra note 231, at 530-31. The legislative history of $\S 1981$ and $\S 16$ of the Civil Rights Act of 1870 is set out in greater detail in Runyon, 427 U.S. at 195-205 (White, J., dissenting).

269. See McClain, supra note 231, at 564-65 (discussing how a coalition of Chinese merchants, associations, and community members met with Congress members to address the issue of justice and equality for Chinese in America).

270. Id. at 566. This political victory was as important as the later legal victory which resulted in a broad reading of the Fourteenth Amendment that extended equal protection "to all persons within the territorial jurisdiction, without regard to any differences of race, of color, or of nationality." Yick Wo v. Hopkins, 118 U.S. 356, 369 (1886).

271. See Charles J. McClain \& Laurene W. McClain, The Chinese Contribution to the Development of American Law, in ENTRY DENIED: EXCLUSION AND THE CHINESE COMMUNITY IN AMEricA, 1882-1943, at 3, 8-15 (Sucheng Chan ed., 1991) (discussing Ho Ah Kow v. Nunan, 5 Sawy. 552 (9th Cir. 1879), which successfully challenged a facially neutral San Francisco cubic-air ordinance that specifically punished Chinese men by cutting off their traditional queues (braids) if they failed to pay the fine for violating the ordinance; and Yick Wo v. Hopkins, 118 U.S. 356 (1886), which successfully challenged the discriminatory application of a facially neutral law aimed at driving the Chinese out of the laundry business).

272. McClain \& McClain, supra note 271, at 16; see also Hiroshi Motomura, Immigration Law After a Century of Plenary Power: Phantom Constitutional Norms and Statutory Interpretation, 100 YALE L.J. 545, 550-54 (discussing Chae Chan Ping v. United States, 130 U.S. 581 (1889), and Fong 
ment of the Chinese American community. In 1882, the United States government passed the first of a series of Chinese exclusion acts, specifically targeting Chinese by severely restricting Chinese immigration. These acts culminated in the Geary Act of 1892, an act called "the most draconian immigration law ever passed."273 This Act reinained valid for over fifty years. To enforce these exclusionary immigration laws, the government set up a special immigration station in 1910 near San Francisco. ${ }^{274}$ Here, hundreds of would-be immigrants were detained for months and were often sent back to China. The Angel Island facility,

Yue Ting v. United States, 149 U.S. 698 (1893), two cases which helped to establish federal plenary power over the immigration and deportation of resident aliens).

273. McClain \& McClain, supra note 271, at 18 (discussing the Geary Act, "An Act to Prohibit the Coming of Chinese Persons into the United States").

Singling out the Chinese by name for discriminatory treatment, the law required that all Chinese legitimately residing in the United States obtain from the collector of internal revenue a certificate affirming their right to be in this country. If a Chinese resident were found without a certificate, he would be subject to immediate and summary deportation unless he could find one white witness to confirm that he had resided in the United States before November 17, 1880 .

Id.

For a discussion of the efforts of Chinese immigrants to circumvent the enforcement of these discriminatory exclusion acts, see Christian G. Fritz, Due Process, Treaty Rights, and Chinese Exclusion, 1882-1891, in ENTRY DENIED, supra note 271, at 25; Lucy E. Salyer, "Laws Harsh as Tigers": Enforcement of the Chinese Exclusion Laws, 1891-1924, in ENTRY DENIED, supra note 271, at 57. Some Chinese immigrants successfully used habeas corpus petitions to gain entry into the United States. Of 7080 petitions filed between 1882 and 1891 in San Franciseo federal courts, 85 to $90 \%$ of these denied cases were reversed. See id. at 58 . Between 1891 and 1905, the 2657 Chinese habeas corpus cases heard in federal courts in San Francisco "continued to frustrate the purposes of the Chinese exclusion laws." Id. at 59. After 1905, recourse to habeas corpus petitions was severely limited by the decision in United States v. Ju Toy, 198 U.S. 253 (1905), overruled by Ng Fung Ho v. White, 259 U.S. 276 (1922). Justice Holmes, writing for the majority, denied the right to a judicial trial to a person of Chinese descent, who claimed to have been born and raised in the United States. Ju Toy, 198 U.S. at 263 . In essence, the decision required that "[t]he courts should abide by the decision of the immigration officials and dismiss all petitions for habeas corpus except those that allege that officials acted unlawfully or abused their authority." Salyer, supra at 79 (citing Ju Toy, 198 U.S. at 261-63).

274. See IsLAND, supra note 227, at 13. "Until 1910, Chinese ship passengers arriving at San Francisco were detained in a two-story shed at the Pacific Mail Steamship Company wharf . . . . As many as 400 to 500 people were crammed into the facility at one time." $I d$. In response to complaints of unsafe and unsanitary conditions, the station on Angel Island was opened, although this relocation was not just for humanitarian rcasons: "Officials also felt that the island location would effectively prevent Chinese immigrants from communicating with Chinese on the outside and would isolate immigrants with allegedly 'communicable diseases prevalent among aliens from oriental countries." Id. Professor Danicls comments:

Although some have called it the "Ellis Island of the West," the analogy is a poor one. Ellis Island and Angel Island were very different kinds of places. For most of the millions who came in via Elis Island, the immigration facility was a mere way station, a fleeting stop at which only a very few-mostly those who could not pass the physical examination-met with disappointment. For most of the thousands who came in via Angel Island, the place seemed a prison in which they were pent up for weeks and months, examined and reexamined, humiliated time and again before being allowed to cross the few hundred yards of water that separated them from the center of Chinese America.

DANiELS, supra note 55, at 93 . 
like Alcatraz Prison nearby, was intended to be escape-proof. ${ }^{275}$

The detainment of Chinese immigrants on Angel Island and the discriminatory treatment they received created a sense of alienation and powerlessness not only in the detainees, but also in those Chinese already in the United States. The detainees were treated like animals or commodities, forced to hive in squalid, cramped quarters. One detainee wrote, "Curled up in an enclosure, iny movements are dictated by others. Enduring a hundred humiliations, I can only cry in vain. This person's tears fall, but what can the blue heavens do?"276 For those Chinese already in the United States, the Chinese Exclusion Acts and the detaininent of Chinese immigrants on Angel Island created a "feeling ainong the Chinese that they were allowed into this country only on the sufferance of the dommant white inajority [which feeling] helped to foster alienation and uminvolvement in the larger society."277 The nunber of persons of Chinese ancestry dropped froin 107,488 in 1890 to 61,639 in $1920 .{ }^{278}$ As their numbers dwindled, most Chinese remained within the security and faniliarity of ethric enclave Chinatowns while others repatriated. The decline in numbers can also be partially attributed to the gender imbalance that hindered fainily formation. ${ }^{279}$

Immigration laws were soon passed which directly attacked the development of existing Chinese coinmumities in the United States. When it appeared that inore Chinese woinen were iminigrating, a new iminigration law was passed in 1924:

One of the law's provisions prohibited the entry of aliens ineligible for citizenship. "The necessity [for this provision]," a congressinan stated, "arises from the fact that we do not want to establish additional Oriental fanilies here." This restriction closed tightly the gates for the immigration of Clinese women. "We were beginning to repopulate a little now," a Chinese inan said bitterly, "so they passed this law to make us die out altogether."280

This provision crippled the development of a stable Chinese American community; ${ }^{281}$ and in conjunction with antimiscegenation laws in many

275. ISLAND, supra note 227 , at 13 .

276. Id. at 60 (footnote omitted).

277. Id. at 28.

278. See DANiels, supra note 55, at 73 tbl. 3.3 (Chinese American Population in California and Other Western States, 1870-1940).

279. Id. at 69 tbl. 3.1 (Chinese American Population, Sex, Citizenship, and Sex Ratio, 18601940). In 1880, the male to female ratio was 21.1 to 1 ; in 1920 , it had dropped to 7 to 1 . Id. The latter figure is deceptive though because most of the females were small children. Id. at 68 .

280. TAKAK1, supra note 1 , at 235 (alteration in original). A portion of this law that excluded wives of American citizens was repealed in 1930. Id.

281. Daniels, supra note 55, at 68 (attributing the slow acculturation of the Chinese American community to a "heavily male-dominated culture, a history of brutal discrimination, extreme residential segregation, and a high degree of cultural differentiation between Chinese and most other Americans"). 
states, ${ }^{282}$ it effectively emasculated an entire generation of male Chinese immigrants. Men in other Asian American groups underwent similar experiences, although the strategies employed were different. ${ }^{283}$

These discriminatory measures remained largely in effect until the passage of the 1952 McCarran-Walter Act, which permitted the naturalization of Asian immigrants and set token immigration quotas. ${ }^{284}$ These quotas, based on national origins quotas established in 1921 and codified in the 1924 National Origins Act, ${ }^{285}$ were not changed until 1965 when the McCarran-Walter Act was amended to abolish the national origins

282. See supra text accompanying note 237 .

283. Japanese immigration had largely been curtailed by the Gentleman's Agreement of 1907 when Japan stopped issuing passports to laborers, by President Roosevelt's Executive Order 589 which prevented remigration to the United States of Japanese laborers from Hawail, Mexico, or Canada, and when Japan stopped issuing passports to picture brides in 1920. See CHAN, supra note 23, at 55. The Immigration Act of 1924 virtually ended Japanese immigration. Id.

Korean immigration began later than Chinese and Japanese inmigration and was curtailed by Japan, which exercised colonial authority over Korea. Id. Approximately 500 Korean nationals managed to leave Korea and enter the United States as political refugees between 1910 and 1924. Id. This practice came to an end with the 1924 Immigration Act. Id. Korean remigration from Hawail to the mainland was stopped by Roosevelt in a 1907 Executive Order. See TAKAKI, supra note 1, at 272. The Korean American community suffered from a gender imbalance that hampered family formation. In 1920 , only $25 \%$ of the mainland population of 1677 Koreans was female. See id. at 270,273 . In 1940, the population of Koreans remained virutally the same, 1711. Id. at 270.

The situation of the Asian Indians was unique because their racial or ethnographic status was unclear. CHAN, supra note 23, at 55. Between 1910 and 1917, inimigration officials tried to limit Asian Indian immigration through the use of administrative regulations. Id. The 1917 Immigration Act, which created a geographic "Barred Zone" effectively ended immigration by Asian Indians. Id.; see also THE TARNISHED GoLDEN DOOR, supra note 244, at 9 (discussing the establishment of the Asia-Pacific Triangle, an Asiatic barred zone, designed to exclude Asians from immigrating to the United States, but exempting an area that included Persia and parts of Afghanistan and Russia).

Filipinos faced yet a different situation because the Philippines became a United States territory after the Spanish-American War. See TAKAKI, supra note 1, at 315. As American "nationals," Filipinos were neither aliens nor citizens of the United States. CHAN, supra note 23, at 55. To solve this problem, the United States made the Philippines a commonwealth with independence to follow in ten years. TAKAKI, supra note 1, at 331. A sponsor of that bill, Senator Millard Tydings, argued, "It is absolutely illogical . . . to have an immigration policy to exclude Japanese and Chinese and permit Filipinos en masse to come into the country." Id. at 331-32 (quoting Senator Tydings). The Tydings-McDuffie Act reclassified Filipinos as aliens and limited immigration to 50 persons a year. Id. at 332. Exclusionists were still unhappy and pressured Congress, which passed a bill in 1935 to repatriate Filipinos, offering them free transportation to the Philippines "on the condition that they forfeit their right of reentry to the United States." Id. at 332-33.

284. 8 U.S.C. $\$ 1101$ (1988).

285. See The TARnished Golden Door, supra note 244, at 9-11. Except for aliens from the Western hemisphere who were exempt from the quotas, quotas for each nationality were set for $2 \%$ of the members of that nationality living in the United States based on the 1890 census. Id. at 9-10. The Act also provided that

[t]he annual quota of any nationality for the fiscal year beginning July 1, 1927, and for each fiscal year thereafter, shall be a number which bears the same ratio to 150,000 as the number of inhabitants in continental United States in 1920 having that national origin (ascertained as hereinafter provided in this section) bears to the number of inhabitants in continental United States in 1920, but the minimum quota of any nationality shall be 100 .

Id. at 10 n.37 (quoting Law of 1924, ch. 190, 43 Stat. 153, 159, § 11(b)). Another provision excluding any alien ineligible for citizenship further limited Asian immigration. Id. at 10. 
system as well as the Asiatic barred zone. ${ }^{286}$ The 1965 amendments profoundly affected the development—or, as Professor Bill Hing states, the "remaking" - of Asian America:

Families moved to "make themselves whole," and women joined their spouses. Workers, particularly in the secondary but also in the primary labor markets, immigrated to take advantage of new opportunities. Asian Americans multiplied, most often in regions and neighborhoods with the cultural and economic capacity to absorb newcomers. ${ }^{287}$

The 1965 anendinents permitted my family to emigrate to the United States from Korea. As an immigrant, I entered this country in the historical context which I have set forth. To an extent, I inherited that legacy of discrimination. I am bound by the still-present stereotype of Asian Americans as "aliens," those who do not belong here and whose presence here is not desired. My colleague at the law school mistakes ine for the "copy boy." Those were not his words, but his question as to whether I was "doing copying for the faculty" inade ine feel very small. When I am stopped by the police for suspicion of possessing a stolen vehicle, ${ }^{288}$ their actions and iny reactions take place in the context of a history of nonresponsiveness to and active harassment of Asian Americans by police. ${ }^{289}$ Maybe it was the kind of car I was driving. Maybe it was the color of iny car. Maybe, just maybe, it was the color of my skin.

I find myself in internal and external conflict when I talk about these things. The internal conflict comes from the fact that I am an inmigrant, and as an immigrant $I$ sometimes wonder if $I$ have a right to complain. This point was brought home to me in an anonyınous student evaluation after iny first year of teaching in law school: "Leave the racist comments out. Go visit Korea if you don't like it here. We need to unit [sic] as a country not drive wedges between us." ${ }^{290}$ I wonder if this student is right.

However, in the same way that $I$ inherit a legacy of discrimination against Asian Americans, I also inherit a legacy of struggle, a struggle that belongs to both foreign-born and American-born Asian Americans. Early Asian immigrants were not politically insular as popular American

286. See id. at 11 (citing Pub. L. No. 89-236, 79 Stat. 911 (1965)).

287. HiNG, supra note 13 , at 80 . For a discussion of how the changes in immigration laws in 1965 affected those Asian immigrant groups already present in the United States, see generally $i d$. at 79-120 (discussing significant effect on Chinese Americans, Filipino Americans, Korean Americans, Asian Indians, and the more limited effect on Japanese Americans).

288. See supra Prelude.

289. See, e.g., Civil RIGHTS REPORT, supra note 7, at $49-57$ (describing numerous incidents of police neglect, harassment, and brutality toward Asian Americans).

290. Anonymous student evaluation, Spring 1993 (copy on file with author). 
history has painted them. ${ }^{291}$ It is our responsibility to bring our forebears back from the silence in which they have been placed. We must recognize that the early Asian immigrants were brave enough to raise their voices. We can do no less.

\section{Disfranchisement}

When I joined the faculty at my former school, the Dean told me that I could participate in faculty meetings. On the first Tuesday of September, I felt proud to attend my first faculty meeting. I did not know then that it would be the last meeting I would attend that semester. As issues came up for decision, I voted, just like the other faculty meinbers. It was only after the meeting that I was told that, as a legal writing imstructor, I was not allowed to vote. My face turned red. I did not returu.

The Dean had not hed to me when he told me that I was allowed to participate in faculty meetings; we simply differed in our interpretation of "participation." From my perspective, the Dean's notion of "participation" was impoverished because I included "meaningful" as part of my defimition of "participation."

To an outside observer, it might appear that I stopped going because I did not care about faculty meetings. But when you listen to my story, you will understand that this is not so.

Systemic disfranchisement-whether at the level of faculty meetings or national elections-discourages many Asian Americans from participating in the political process. This is reflected in the low voter registration statistics which show Asian Americans to be "grossly underrepresented in terms of their voting power in relation to their numbers in the population." ${ }^{292}$ This political silence has been attributed to "cultural differences, the difficulty of combining Asian Pacific American subgroups into a cohesive 'minority' group because of their diverse nationalities and generations, and their lack of interest in politics."293 These reasons, however, are largely myths created to prevent the enfranchisement of Asian Americans. ${ }^{294}$ The low voter registration

291. See TAKAKI, supra note 1, at 112-14; see also RACISM AND SEXISM RESOURCE CTr. FOR EDUCATORS, supra note 25.

292. Bai, supra note 218, at 737 (quoting G. Din, An Analysis of Asian/Pacific American Registration and Voting Patterns in San Francisco 86 (1984) (unpublished M.A. thesis, Claremont Graduate School)). Studies in areas with significant Asian Pacific American populations showed similar findings. Id. at 736-38.

293. Id. at 733 (footnotes omitted).

294. Id. at 735-48 (discussing the findings of various studies suggesting that low voter turnout among urban Asian Americans is more a function of external barriers and discrimination than sociocultural problems). 
figures can be attributed to several specific barriers that prevent Asian Ainericans froin participating in a meaningful manner.

The greatest historical barrier to Asian American participation in the political process was the fact that Asian Americans could not become naturalized ${ }^{295}$ and could therefore not vote since only citizens had that right. Some states even prohibited American-born Asians from voting. ${ }^{296}$ This historical exclusion has an mertia that carries into the present. Yet the dominant culture, and in particular, the legislature and judiciary, do not understand because they are largely unaware of this pattern of formally excluding Asian Americans.

In fact, according to the Civil Rights Report, formal barriers to political participation still exist:

1) apportionment policies that dilute the voting strength of Asian American voting blocks; 2) the unavailability of Asian-language ballots and other election materials; 3 ) problems with the impleinentation of the Census of Population; and 4) anti-Asian sentiments among non-Asian voters and the media and the consequent dearth of Asian American political candidates (which may also be partly caused by political parties that ignore the Asian American population and do not actively seek or promote Asian candidates). ${ }^{297}$

I address the first two barriers examined by the Civil Rights Commission. ${ }^{298}$

Two current apportionment policies dilute Asian American voting strength: (1) the splitting of the Asian American population in an area into several voting districts, ${ }^{299}$ and (2) the establishment of at-large election systems in areas of high Asian American population. ${ }^{300}$ Attempts to redress Asian American vote dilution are hindered by a United States

295. See supra notes $244-46$ and accompanying text.

296. See, e.g., CAL. Const. art. II, $\S 1$ (1911).

297. Civil RightS REPORT, supra note 7, at 159 (footnotes omitted).

298. As for the third factor, the Census provides a barrier in two ways: (1) no forms use Asian languages, and (2) data on Asian Americans from the 1980 census was not released until 1988. The latter factor is important in establishing whether Asian Americans constitute a language minority for the purposes of the Voting Rights Language Assistance Act. See infra notes 303-07 and accompanying text.

The importance of the fourth factor can be seen in the results of exit polls which show that $71 \%$ of Asian American voters would vote more often "if more Asian candidates ran for office." Bai, supra note 218, at 749 (quoting results of Asian American Legal Defense and Education Fund, New York, exit polls).

299. For example, the Los Angeles Koreatown, Chinatown, and Filipinotown areas are each split into multiple districts. CIVIL RIGHTS REPORT, supra note 7, at 159.

300. An example of at-large districts diluting the strength of Asian American votes can be seen in Daly City, California, where Asian Americans (primarily Filipino Americans) constitute over $42 \%$ of the city's population. See id. at 157, 159: Yet the first Filipino American to serve on the city council was elected this year. See Benjamin Pimentel, Filipinos Finally Get Voice on Daly City's Council, S.F. CHRON., June 21, 1993, at A13. 
Supreme Court decision which requires that a minority group "be able to demonstrate that it is sufficiently large and geographically compact to constitute a majority in a single-1nember district." ${ }^{301}$ One problem with this requirement is that it excludes Asian Americans, many of whom are geographically dispersed, at times imvoluntarily, through the will of the government. ${ }^{302}$

Another formal mechanism that prevents greater voter participation among Asian Americans is the use of Enghish-only ballots. Congress, recognizmg the probleins with Enghish-only ballots, amended the Voting Rights Act in 1975 and again in 1982 to provide language assistance to "language minorities." 303 However, these measures did not take into account the distinct problems facing Asian Alnericans. Congress, in establishing that a language minority inust constitute at least five percent of the voting age population, did not consider the diversity of languages and cultures among Asian Americans. Thus, even if the Asian American population in a given political subdivision were greater than the requisite five percent, no single Asian American language minority constituted a large enough group to benefit from the Act's provisions. ${ }^{304}$ As a result, no Asian American groups were able to clain the status of a "language minority" under that ainendment.

This did not change until the voices of Asian Americans spoke our distinct problems into existence. Because Asian Americans were unable to constitute language minorities for the purposes of the 1982 Voting Rights Act, ineinbers of the coinmunity began to voice concerns and to protest the 1982 Act. Many participated in Roundtable Conferences on Civil Rights sponsored by the United States Commission on Civil Rights. $^{305}$ Their efforts led to the 1992 amendinent to the Voting Rights

301. Thornburg v. Gingles, 478 U.S. 30, 50 (1986).

302. See Bai, supra note 218, at 757 n.125 (discussing the internment of Japanese Amerieans durirng World War II which destroyed many Japanese American communities and the government's appeals to Japanese Americans not to return to those communities in California, recent urban renewal programs which have forced many Asian Americans out of ethnic communities such as Chinatowns, and the purposeful dispersal of Southeast Asian refugees throughout the United States to lessen the burden on a particular community).

303. 42 U.S.C. §1973aa-1a (1988); H.R. Rep. No. 655, 102d Cong., 2d Sess. 3 (1992). Congress found that

through the use of various practices and procedures, citizens of language minorities have been effectively excluded from participation in the electoral process. Among other factors, the denial of the right to vote of such minority group citizens is ordinarily directly related to the unequal educational opportunities afforded them, resulting in high illiteracy and low voting participation.

42 U.S.C. § 1973aa-1a(a).

304. Other minority groups were able to establish themselves as a language minority under the act. H.R. REP. No. 655 , supra note 303 , at 4 . In pointing this out, I do not mean to imply that all the voting barriers of other minority groups were removed. They were not. Id.

305. CIVIL RIGHTS REPORT, supra note 7, at 157 ("[T] he participants . . cxpressed concern about Asian Americans' lack of politieal representation and political empowerment and decried the dearth of Asian American elected officials and political candidates."). 
Act, ${ }^{306}$ which led to the enfranchisement of many Asian Americans. ${ }^{307}$

Achieving enfranchisement is only the first step toward meaningful political participation and social change. The next step is to elect legislators and appoint public officials who will address and respond to the unique needs of Asian Americans. In legislative halls, executive agencies, and judicial cliambers, the law is made and implemented, but Asian Americans, perhaps more so than other disempowered groups, have not yet been able to enter these doinains in a significant way. Nevertheless, the voting rights example shows low legal reform can be brought about when Asian Americans participate in the political process and give voice to our oppression and our needs.

\section{B. Speaking Our Oppression into (and out of) Existence}

Earlier, I showed how the post-structural critique revealed the fallacy of the current search for political legitination and tliat the real political question is and always was about power. ${ }^{308}$ One way to gain power is through the use of physical force. Another way is through the use of verbal force. 309 Both are "legitimate" metliods of persuasion. . $^{310}$ Narratives play an inportant role in this gaine of persuasion. The use of narratives by Japanese Americans, in the form of testimony before Congress, played an instruinental role im the passage of the Redress and Reparations Act. As more groups use narratives to combat discrimination, they effectively "ffesli out" tlie diversity within Asian America, making legislators and other policy-inakers realize that many Asian Americans do not fit the "model ininority" stereotype.

\section{The Japanese American Internment and Redress}

Much has been written about the internment of Japanese Americans during World War $\mathrm{II}^{311}$ and tlie Supreme Court decisions upliolding tlie

306. 42 U.S.C.A. $\$ 1973 a a-1 a$ (West Supp. 1992) (amending 42 U.S.C.A. $\S 1973 a a-1 a(1988)$ ). The amendment changed the former five percent requirement so that language assistance would be required if a single language minority constituted more than five percent of voting-age citizens in a political subdivision or "more than 10,000 of the citizens of voting age of ... [a] political subdivision are members of a single language minority and are limited-English proficient." Id.

The House Report includes contributions from the Japanese American Citizens League; Charles Pei WVang, Vice Chairman, United States Commission on Civil Rights; and Harry Low and Yvonne Lee, National President and National Executive Director of the Chinese American Citizens Alliance, respectively. H.R. REP. No. 655, supra note 303, at $7 \mathrm{nn} .16$ \& 17, $8 \mathrm{n} .19$ (1992).

307. Without the new amendment, over 60,000 Asian American citizens in Los Angeles alone would remain disfranchised. Id. at $8 \mathrm{n} .19$.

308. See supra note 213 and accompanying text.

309. Cf. Robert M. Cover, Violence and the Word, 95 YALE L.J. 1601, 1609-18 (1986) (discussing the links between judges' legal interpretations and violence). Verbal force is not the same thing as narrative.

310. I bracket "legitimate" to emphasize its malleable nature.

311. See generally ANSEL ADAMS, BORN FREE AND EQUAL (1944) (documenting through photographs and text the Japanese American internment experience at Manzanar Relocation Center 
legality of the government's actions. ${ }^{312}$ I will not repeat that discussion. Instead, I will focus on the process of breaking the silence, which in conjunction with the work of Japanese American members of Congress, brought about redress and reparations. ${ }^{313}$

\section{We were told}

that silence was better

golden like our skin, useful hike

go quietly, easier like

in Inyo County, California); PETER IRoNs, JUSTICE AT WAR (1983) (telling the stories of four Japanese Americans who challenged the constitutionality of the internment orders); JAPANESE AMERICANS: FrOM RELOCATION TO REDRESS (Roger Daniels et al. eds., rev. ed. 1991) (providing historical and personal discussions of the internment experience and the redress movement); $\mathrm{MrCHI}$ Weglyn, Years of INFamy: The Untold Story of Amenica's Concentration Camps (1976) (providing historical analysis of the internment period). For an extensive bibiliography of materials about the Japanese American internment, see ASIAN AMERICAN STUdies: AN ANNotated Bibliography aND RESEARCH GuIDE 209-33 (Hyung-chan Kim ed., 1989).

312. With the exception of Ex parte Endo, 323 U.S. 283 (1944) (granting habeas corpus petition because the loyalty of Endo was conceded and Congress had not authorized detention of loyal American citizens), three cases, Korematsu v. United States, 323 U.S. 214 (1944), Hirabayashi v. United States, 320 U.S. 81 (1943), and Yasui v. United States, 320 U.S. 115 (1943), upheld various measures enforcing the exclusion and internment of Japanese Americans. Gordon Hirabayashi's and Fred Korematsu's convictions were eventually overturned after they each petitioned for writ of coram nobis. Hirabayashi v. United States, 828 F.2d 591 (9th Cir. 1987); Korematsu v. United States, 584 F. Supp. 1406 (N.D. Cal. 1984). Minoru Yasui died before the appeal of the dismissal of his petition could be heard. JUSTICE DELAYED: THE RECORD OF THE JAPANESE AMERICAN INTERNMENT CASES 29 (Peter Irons ed., 1989). Only 12 Japanese Americans in all challenged the exclusion orders in court. IRONS, supra note 311 , at 75.

Irons gives a partial explanation of why so few Japanese Americans sought redress through the legal system, but his account is ultimately unsatisfactory because it does not look at the broader historical context within which the internment took place. Professor Gotanda criticizes Irons for not critically re-examining the events and for failing to place the events in a broader historical perspective. Gotanda, supra note 106, at 1187.

Korematsu, of course, has never been explicitly overruled. In fact, the internment of Japanse Americans during World War II was generally upheld in the interests of national security, even though doing so granted the military broad power and robbed civilians of individual rights and freedoms. Eric K. Yamamoto, Korematsu Revisited-Correcting the Injustice of Extraordinary Government Excess and Lax Judicial Review: Time for a Better Accommodation of National Security Concerns and Civil Liberties, 26 SANTA CLARA L. REV. 1, 3 (1986) (examining the revival of the deferential standard of review applied in Korematsu in light of recent national security cases). For additional discussions of the grounds of the Court's opinion in Korematsu, see JACOBUS TENBroEK et Al., Prejudice, War AND the Constitution (1954); Nanette Dembitz, Racial Discrimination and the Military Judgment: The Supreme Court's Korematsu and Endo Decisions, 45 Colum. L. REV. 175 (1945); Eugene V. Rostow, The Japanese American Cases-A Disaster, 54 YALE L.J. 489 (1945).

313. The success of the Japanese Americans in gaining reparations has breathed new life into the African American reparations movement. See Vincene Verdun, If the Shoe Fits, Wear It: An Analysis of Reparations to African Americans, 67 TuL. L. REv. 597, 646-59 (1993) (comparing Japanese American and African American claims to reparations); see also Rhonda V. Magee, Note, The Master's Tools, From the Bottom Up: Responses to African-American Reparations Theory in Mainstream and Outsider Remedies Discourse, 79 VA. L. REv. 863 (1993). 
don't make waves

expedient like lorsestalls and deserts. ${ }^{314}$

Although it is difficult to determine when exactly the redress movement began, ${ }^{315}$ it did not receive national attention until the 1978 Japanese American Citizens League (JACL) national convention. ${ }^{316}$ In 1978, the JACL adopted redress as its priority issue and sought a " $\$ 25,000$ compensation figure plus the creation of a Japanese American Foundation to serve as a trust for funds to be used for the benefit of Japanese American communities througliout the country."317 The national attention came when Senator S.I. Hayakawa, im an interview during the convention that was carried by newspapers nationwide, called the JACL's demand for redress "absurd and ridiculous."318 The inedia attention that followed gave Japanese Americans their first opportunity "to talk publicly about wliat tliey experienced during World War II."319

314. Janice Mirikitani, Breaking Silence, in Shedding Silence 33, 33 (1987). In this poem, Mirikitani juxtaposes text from her mother's testimony before the Commission on Wartime Relocation and Internment of Japanese American Civilians with her feelings in reaction to the relocation experience. Id. at 33,36. Mirikitani's mother broke 40 years of silence in giving this testimony about the experience of interned Japanese Americans. When told that she had a limited time, Mirikitani's mother responded:

Mr. Commissioner . . .

So when you tell me I must limit

testimony,

when you tell me my time is up,

I tell you this:

Pride has kept my lips

pinned by nails

my rage coffined.

But I exhume my past

to claim this time.

Id. at $\mathbf{3 5}$ (alteration in original).

315. Roger Daniels, Introduction to Part VII of JAPANESE AMERiCans: From Relocation To REDRESS, supra note 311 , at 188,188 . Professor Daniels discusses several early activities during the 1940s but attributes the origin of the present-day redress movement to small groups of Japanese Americans in Southern California, San Francisco, and Seattle who began demanding compensation for the wrongful treatment of Japanese Americans during World War II. Id.

316. John Tateishi, The Japanese American Citizens League and the Struggle for Redress, in JAPANESE AMERICANS: From RELOCATION TO REDRESS, supra note 311, at 191, 191. The redress issue had been raised within the JACL as early as the 1970 JACL convention in Chicago, but differing views prevented the JACL from reaching a single, coherent position. Id.

317. Id.

318. Id. at 192. This same Senator S.I. Hayakawa made the following comment in 1971 about the relocation and internment:

All the people I know have a very positive attitude towards it. The ones I know in Chicago say, "We would have never gone to Chicago, if it hadn't been for the wartime relocation. We would have all been hung along a little strip of the Pacific coast and would have never discovered San Francisco, or New York, or Chicago, Omaha, or Minneapolis, where the Japanese are scattered all over the place. So this really gave us a chance to really become Americans instead of residents of Little Tokyo in Los Angeles."

An Interview with S.I. Hayakawa, President of San Francisco State College, in Roots, supra note 77, at $19,21$.

319. Tateishi, supra note 316, at 192 . Before then, many Japanese Americans remained silent because they had "been infused with a philosophy that stresses: 'Let's make the most of a bad 
Initial reactions to the movement were mixed, both within and without the Japanese American commumity. Within the Japanese American community, "many . . . initially rejected redress for a variety of reasons. Some msisted that no amount of money could compensate them for their suffering; others saw it as a kind of welfare, while still others thought that it was best not to reopen the wounds of the past."320 Many on the outside "were shocked that a 'model minority' should make such strident demands."321

However, in 1980, the government began to respond to demands for redress with the Congressional establishment of the Commission on Wartime Relocation and Internment of Civilians. ${ }^{322}$ The Commission held hearings in several cities, at which more than 750 Japanese American internees testified about their experiences. ${ }^{323}$ This process "forced large numbers of the survivors to come to grips-often publicly at hearings or in community meetings-with their own long-suppressed feelings about their wartime experiences." 324

To many, telling their stories provided a much-needed catharsis. ${ }^{325}$ The stories also provided a compelling moral force to the claims of redress. One survivor related how he had destroyed his home before he was evacuated:

I went for my last look at our hard work. ... Why did this thing happen to me now? I went to the storage shed to get the gasoline tank and pour the gasoline on my house, but my wife ... said don't do it, maybe somebody can use this house; we are civilized people, not savages. ${ }^{326}$

Others described the conditions im the camps. One survivor commented, "I was too young to understand, but I do remember the barbed wire fence from which my parents warned me to stay away. I remember the sight of high guard towers. I remember soldiers carrying rifles, and I remember being afraid." 327 All evacuees were given numbers; the numbering process was a particularly disheartening experience. ${ }^{328}$ The

situation and push ahead," and had "internalized the subtle ways in which the larger society reminds one to stay in his place." Isao Fujimoto, The Failure of Democracy in a Time of Crisis: The War-Time Internment of the Japanese Americans and its Relevance Today, in RooTs, supra note 77, at $207,207$.

320. Daniels, supra note 315 , at 189.

321. Id.

322. Tateishi, supra note 316, at 193. President Carter signed Public Law No. 96-317 establishing the Commission on July 31,1980 . Id.

323. Id. at 194.

324. DANiELS, supra note 55, at 336-37.

325. Id. at 337.

326. Commission on Wartime Relocation and Internment of Civilians, Personal. Justice Denied 132 (1982) (quoting John Kimoto) [hereinafter Personal Justice DeNied].

327. Id. at 176 (quoting George Takei).

328. Id. at 135. An evacuee remarked, "I lost my identity. At that time, I didn't even have a Social Security number, but the WRA gave me an I.D. number. That was my identification. I lost 
internment left a scar on the Nisei; it has become a "point of reference" in their lives. ${ }^{329}$ A son of camp survivors remarked:

When I first learned of the internment as a youth, I found that it was a difficult inatter to discuss with my parents. My perception of them was that they did not speak honestly about the camp experience. Positive aspects were mentioned, if anything at all, but there always seemed to be something that was left out. My feeling was that there was much more to their experience than they wanted to reveal. Their words said one thing, while their hearts were holding something else deep inside. ${ }^{330}$

The Commission released its findings in $1982,{ }^{331}$ concluding that "Executive Order 9066 and the internment that it sanctioned resulted froin 'race prejudice, war hysteria, and a failure of political leadership." "332 The Commission further presented five recommended remedies. ${ }^{333}$ These included a recommendation that an official apology be issued and that each surviving internee be given $\$ 20,000 .^{334}$ The Commission's report and recommendations as well as the work of Japanese American congressmen ${ }^{335}$ paved the way for the redress bill, which was passed by the House in September 1987 and by the Senate in April 1988. ${ }^{336}$ The government began making payments on October 9, 1990.337

Professor Chan comments that " $[t]$ he redress movement has been a prime example of how Asian American elected officials have worked hand in hand with commumity activists toward a common end."338 But this "end" did not come about until the "model minority" broke its silence, demonstrating the power of narrative through testimony about the injustice of the internment camps.

my privacy and dignity." Id. (quoting Betty Matsuo). Another commented, "Henry went to the Control Station to register the family. He came home with twenty tags, all numbered 10710, tags to be attached to each piece of baggage, and one to hang from our coat lapels. From then on, we were known as Family \#10710." Id. (quoting Monica Sone).

329. Id. at 297.

330. Id. (quoting Michael Yoshii).

331. See generally Personal Justice Denied, supra note 326.

332. CHAN, supra note 23 , at 174 .

333. Tateishi, supra note 316 , at 195.

334. Id.

335. See CHAN, supra note 23, at 174 ("Despite the commission's findings, it took extraordinary effort to marshal support for a redress bill that could pass both houses of Congress. The Japanese Amerieans in the U.S. Senate and House of Representatives prepared each step with care and bided their time.").

336. Id. The margin of victory in the House was 243-141; in the Senate, 69-27. Id.

337. Roger Daniels, Redress Achieved, 1983-1990, in JAPANESE AMERICANS: From RELOCATION to REDRESS, supra note 311, at 219, 219.

338. CHAN, supra note 23 , at 174 . 


\section{The Not So Model Minority}

While Japanese Americans may enjoy some apparent economic advantages compared to other Asian American groups, ${ }^{339}$ the reality is that many Asian Americans, particularly recent immigrants, are neither economically well-off ${ }^{340}$ nor pohitically empowered. ${ }^{341}$ Because the problems of these "not so model minorities" are rarely given voice, I will tell the stories of one such Asian American subgroup-Asian immigrant garment workers.

\section{After sewing, laundry, cleaning and cooking, I have no breath left to sing. ${ }^{342}$}

In Chma, Chan Wai Fun (not her real name) ${ }^{343}$ worked as an office manager and sang Chinese opera. ${ }^{344}$ She immigrated to the United States in 1985, and, like many other Asian immigrant women who have recently arrived in America, ${ }^{345}$ she entered the garment industry. ${ }^{346}$

339. See supra note 94 and text accompanying note 95 .

340. See supra text accompanying notes 82-83; see also note 97.

341. See supra Part III.A.2.

342. Louie, supra note 96 , at 10 (quoting a garment worker).

343. Id. Garment workers who provide information to outsiders often request anonymity because they fear reprisals. This fear, among others, prevents them from bringing official complaints:

First, complaining about pay or mandatory overtime can mcan facing a retaliatory dismissal and being blacklisted at other local apparel shops. Second, garment workers believe that if officials discover any labor violations in their workplaces, this will force shop owners out of business, leaving the workers themselves without jobs. Third, . . . undocumented workers fear that filing an official complaint may not only fail to improve shop conditions, but may also lead to investigations of their individual immigration statuses and possible deportation.

Leo L. Lam, Note, Designer Duty: Extending Liability to Manufacturers for Violations of Labor Standards in Garment Industry Sweatshops, 141 U. PA. L. REV. 623, 640 (1992) (footnotes omitted).

344. Louie, supra note 96 , at 10.

345. Id. at 1 ("[T]housands of Asian immigrant women bend over machines in sweatshops tucked in Chinatowns, Little Saigons, and Koreatowns across the country.'). Hispanics (60\%) and Asians (35\%) comprise most of the labor force in the United States garment industry. Lam, supra note 343 , at 632 n.53. Women are also overrepresented in this inclustry. Id. at 632 .

346. Louie, supra note 96, at 10. Although the largest centers for the garment industry are New York City, Los Angeles, and San Francisco, "this far-reaching industry also extends to many major cities in the South and Southwest such as Miami, New Orleans, and San Antonio. Nationwide, garment workers number over one million and the industry is dominated by small companies." Lam, supra note 343, at 628 (footnotes omitted).

Lam characterizes the garment industry as a chain, consisting of "the retailer, usually a department store or boutique; the manufacturer, for example, Levi-Strauss; the contractor (or 'subcontractor' relative to the manufacturer) or shop owner; and the garment worker." Id. at 629 (footnote omitted). A $\$ 120$ profit is distributed along the chain as follows: "profit to the retailer is $\$ 60$; profit to the manufacturer is $\$ 25$; profit to the contractor is $\$ 10$ at a cost to the contractor of $\$ 25$, of which only $\$ 2.40$ goes to the worker." Id. at $629 \mathrm{n.36}$ (citing statistics appearing in Steven A. Chin, Sweatshops: Bay's Ugly Secret, S.F. ExAmINER, Feb. 13, 1989, at A1, A10). The general structure of the garment industry insulates those who benefit most, the manufacturers, from being held liable for the contractor's labor and wage violations. See id. at 629-31; see also Hayashi, supra note 96, at 199 ("By characterizing their relationship with contractors as independent, [manufacturers] have avoided legal responsibility for workers' compensation, unemployment 
Like other immigrant women, Chan desperately wants to learn Enghish in order to get a better job, but also like these other immigrants, she is trapped $\mathrm{m}$ her job because she does not have the time or energy to study Enghish. ${ }^{347}$ One commentator describes the cycle of poverty reinforced by the garment and restaurant industries in Chinatown:

They coine over, they don't speak Enghish, the man gets a job in a restaurant and the woman in a garment factory down here. In a few years, they think they'll learn English, save some money, and move out. Everyone talks about that. But . . . they've lived in Chinatown all ten or twenty years. They earn just enough to keep going, they've hardly saved at all. They don't get exposed to English at work, they're too tired to study at might. The job they got to tide over ends up as a life-time occupation. It's like a vicious cycle. If they didn't have the garment industry, or those restaurant jobs, a lot of people in Chinatown wouldn't make it. But as long as they have those jobs, they'll never get out of here. ${ }^{348}$

Although Wai Fun las "no breath left to sing,"349 she is one of the lucky few in that she earns five dollars an hour for her labor. ${ }^{350}$ Many garment workers receive less than half the federal minimum wage. ${ }^{351}$ The truly unfortunate workers receive nothing at all.

Four hundred fifty garment workers in San Francisco and Oakland allnost learned this harsh lesson when they showed up for work on July

insurance and fringe benefits."). This system has remained firmly in place despite reform efforts. The two most recent attempts at legislative reform in California would have held manufacturers liable to some extent for labor law violations by their subcontractors and contractors, but both bills were eventually vetoed. See Lam, supra note 343, at 653-54. For earlier criticisms and suggested reforms, see Harold P. Dygert III \& David Shibata, Note, Chinatown Sweatshops: Wage Law Violations in the Garment Industry, 8 U.C. DAv1s L. REV. 63 (1975); Barbara Koh, Note, Alterations Needed: A Study of the Disjunction Between the Legal Scheme and Chinatown Garment Workers, 36 STAN. L. REv. 825 (1984).

347. Louie, supra note 96 , at 10-11.

348. Dygert \& Shibata, supra note 346, at 83 (quoting B. DE NEE \& V. DE NEE, LoNGTIME CALIForn': A DocumentaRy STUDY of AN AMERICAN CHINATOIVN 317 (1972)).

349. Chan Wai Fun "works a minimum of nine-and-a-half hours a day, six days a week without benefits or overtime pay." Louie, supra note 96 , at 10. In order to hide wage violations, she and her fellow workers "keep two sets of timecards, one to punch in the time clock and one where [they] write down [their] real hours." Id. (quoting Chan Wai Fun).

350. Id. At her first job, she was paid by the piece and averaged two dollars an hour. Id. A recent survey of 230 San Francisco shops disclosed that $80 \%$ either did not pay overtime at all or did not pay overtine in full. Jack Viets, State Panel Hears Garment Workers' Case, S.F. Chron., June 22, 1991, at A12. In $1990,86 \%$ of the almost 1700 garment shops visited by inspectors from California's Department of Industrial Relations were cited for labor law violations. Hayashi, supra note 96, at 197. In New York City "[i]n over 5000 investigations since 1987, the State Labor Department has found in addition to 2100 unregistered shops, 500 minimum wage violations, 2000 reports of unsafe working conditions, and over 600 child-labor violations." Lam, supra note 343, at 634.

351. Lam, supra note 343 , at 633 . 
17, 1991, only to find their workplace doors padlocked. ${ }^{352}$ Their employers, Raymond and Yee Nor Kong, disappeared, leaving the workers with problems far greater than the immediate loss of their jobs:

The Kongs had not paid them for two months, claiming that money was tight and that compensation would follow when cash became available. The Kongs had borrowed substantial sums from their employees, threatening to termmate workers who would not lend them money. Furthermore, the Kongs had ceased paying health insurance premiums, despite having deducted money from employees' paychecks for this purpose. ${ }^{353}$

Fortunately for these workers, most of whom were Southeast Asian immigrants who spoke hittle Enghish and did not understand their rights as employees, a total loss was averted:

[T]he International Ladies Garment Workers Union ("ILGWU") provided help in filing claims for lost wages and in preventing large creditors from seizing the Kongs' assets before the lost wages were paid. Furthermore, Byer California, a clothing manufacturer which held production contracts with the Kongs, paid $\$ 200,000$ to the State Labor Commissioner's Office to help cover the unpaid wages of the workers in an act of apparent goodwill. ${ }^{354}$

Twelve woinen who worked for the Lucky Sewing Company in Oakland Chinatown discovered, though, that one cannot depend on the generosity of inanufacturers. In May of 1992, these woinen found themselves uneinployed; without any notice, their employer, like many other garment shop owners, had closed down the sweatshop and filed for bankruptcy. ${ }^{355}$ These twelve workers were owed approximately $\$ 15,000$ in back wages. 356

Since these women knew that they had sewn dresses for San

352. A discrepancy exists as to the date of closure and the number of garment shops. Compare Hayashi, supra note 96, at 195 (reporting July 17, 1991, and nine sliops) with Lam, supra note 343, at 625 (reporting July 13, 1991, and eight shops). Newspaper accounts support July 17 as the date workers discovered the padlocked shops, see, e.g., Steven A. Chin, Garment Firm's Owners Sought, S.F. EXAMINER, July 22, 1991, at A1, A9, but differ over the number of shops. Compare id. (listing eight shops, seven in San Francisco and one in Oakland) with Seamstresses Want Their Pay, SACRAMENTO BEE, July 21, 1991, at B3 (listing nine shops, eight in San Francisco, one in Oakland). This discrepancy is irrelevant in discussing the plight of immigrant garment workers, but highlights the problems that exist even when using "primary" and "secondary" sources of "objective" information.

353. Hayashi, supra note 96 , at 195.

354. Lam, supra note 343, at 626 (footnote omitted). A question exists as to whether goodwill was involved. See Dexter Waugh, Stranded Garment Workers Get $\$ 305,000$ in Back Pay, S.F. EXAMINER, Aug. 22, 1991, at A8 ("The money [\$305,000], on deposit with state and federal labor officials, came from two companies-Byer California and The Gap-which owed it to the Kongs for finished merchandise.").

355. Telephone Interview with Sharon Tang, Administrative Assistant, Asian Immigrant Women Advocates (Oct. 4, 1993).

356. Steven A. Chin, Seamstresses Ask Designer for Pay, S.F. ExAMINER, Oct. 5, 1992, at A1. 
Francisco fashion designer Jessica McClintock, several of them visited the Jessica McClintock boutique in San Francisco in August. ${ }^{357}$ The workers were shocked to find dresses like the ones they had sewn selling for $\$ 175 .{ }^{358}$ One seamstress with seven years' experience commented, "I was angry. I didn't expect our dresses to sell for such a high price." 359 This worker, who was owed $\$ 3000$ for approximately two and a half months' of work, had worked seven days a week, ten hours a day, and had not received even the $\$ 5$ that she should have been paid for sewing that $\$ 175$ dress. ${ }^{360}$

With the help of community activists, the workers asked Jessica McClintock to compensate them for approximately $\$ 2000$ of the $\$ 15,000,{ }^{361}$ but McClintock refused. ${ }^{362}$ A national media campaign and boycott against her goods ensued, ${ }^{363}$ but the garment workers remam unpaid. ${ }^{364}$

Jessica McClintock is at present not legally hable for the workers' back wages, but garment inanufacturers should be held hable for the labor law violations of their subcontractors in order to improve working conditions in the industry. Others have set forth the legal basis for nianufacturer liability; ${ }^{365}$ the narrative accounts of the garment workers' experiences provide inoral force for bringing about such a change. Because niany Asian American problems are clouded and silenced by such misperceptions as the inodel minority myth, change will occur only when voice is given to the stories of the diseinpowered. Stories such as that of Chan Wai Fun caught in a cycle of poverty, or of the workers abandoned by the Kongs, or of the woinan who does not receive $\$ 5$ in wages for work on a dress retailing for $\$ 175$, provoke the sense of nioral outrage that is often a necessary precursor for change.

The law review articles or notes arguing for garment manufacturer

357. See id. at $\mathbf{A} 12$.

358. Id.

359. Id. (quoting a seamstress who requested anonymity for fear of being blacklisted by local garment shops).

360. Id.

361. Id. at A1. The workers were left holding bounced paychecks that were traced back to McClintock. See Katharine Fong, Ripping at the Seams, S.F. WKLY., Dec. 30, 1992, at 17.

362. See Chin, supra note 356 , at A1 ("McClintock has already paid the factory owner for the dresses and under state law isn't responsible for the workers' wages. . . She said in a letter to [the workers] Thursday [Oct. 1, 1992] that her company had last done business with Lucky Sewing Co. more than a year ago.").

363. See Newsletter from Asian Immigrant Women Advocates to Supporters of the Garment Workers' Justice Campaign (Asian Immigrant Women Advocates, Oakland, CA) (Dec. 22, 1992) (on file with author) (setting forth highlights of the campaign and activities by groups in other cities supportive of the campaign).

364. Telephone Interview with Sharon Tang, supra note 355.

365. See generally Hayashi, supra note 96; Dygert \& Shibata, supra note 346; Lam, supra note 343. 
liability appeared in $1975,{ }^{366} 1984,{ }^{367}$ and $1992 .{ }^{368}$ Each was written or cowritten by an Asian American. But little has changed. With the development of an Asian American Legal Scholarship, Asian American writers will be able to speak our oppression into and out of existence. I hope, then, that I will not have to read another article about this problem eight or nine years from now. I hope that there will no longer be a need for such an article.

\section{The Common Thread}

Often it is easy for those of us who are relatively privileged to ignore the problems faced by many segments of the Asian American population. For exainple, as I sit in my office preparing for a class or working on this article, I wonder what I have in common with the man who has been denied a job because of his accent. ${ }^{369}$ I wonder what $I$ have in common with the person who cannot read the English-only ballot in the voting booth.

\section{"Not me, not me." 370}

These words did not protect Nguyen Hen Van, a Vietnamese man who had been charged with theft, but who was tried as the defendant in a murder trial because the jail staff brought the wrong man from the jail cell. Even more frightening is that

[t]wo testifying witnesses in the murder trial even identified Mr.

Nguyen as the murderer. The actual murder defendant was

Nguyen Ngoc Tieu, also Vietnamese, who was sitting in the county jail three blocks away. Even Mr. Tieu Nguyen's lawyer, who had interviewed him for an hour only 2 weeks before the trial did not realize that the wrong man was on trial, even when $\mathrm{Mr}$. Hen Van Nguyen tried to protest saying, "Not me, not me."371

The mistake was not realized until near the end of the trial when someone recoguized Mr. Hen Van Nguyen as the wrong defendant and a mis-

366. See Dygert \& Shibata, supra note 346.

367. See Koh, supra note 346.

368. See Hayashi, supra note 96; Lam, supra note 353.

369. See Fragrante v. City of Honolulu, 699 F. Supp. 1429 (D. Haw. 1987), (holding that the effect of a Filipino man's accent on his ability to communicate was valid grounds to refuse his promotion), aff'd, 888 F.2d 591 (9th Cir. 1989), cert. denied, 494 U.S. 1081 (1990). For an analysis of this case, see Matsuda, supra note 172, at 1333-40; see also Beatrice Bich-Dao Nguyen, Comment, Accent Discrimination and the Test of Spoken English: A Call for an Objective Assessment of the Comprehensibility of Non-native Speakers, 81 CALIF. L. REv. 1325 (1993) (arguing that an objective test is necessary to protect people from subjective accent discrimination).

370. Civil Rights RePORT, supra note 7, at 169 (quoting Nguyen Hen Van, a Vietnamese man mistakenly idenitifed and tried as a murderer, as reported in Mixup in Court: Wrong Vietnamese Defendant Undergoes Two Days of Murder Trial, SeatTLE Times, Oct. 26, 1985).

371. Id. 
trial was declared. ${ }^{372}$

Mr. Hen Van Nguyen's case of mistaken identification had a happy ending. Vincent Chin was not so lucky. ${ }^{373}$ Besides being unable to distinguish among mdividual Asian Americans, whites sometimes blur the lines between all racial minorities. When I was in sixth grade, after enduring a month of name-calling by most of my classmates, I was called a "nigger" by a student. Part of me wanted to yell, "Not me, not me." But the plea "not me, not me" is not a defense to hate. When that hate is directed not at you as an individual, but at you because of the color of your skin or the slant of your eyes, you begin to understand that any level of privilege you might attain will not protect you from hate. You will still be vulnerable.

I learned this at a bowling alley during my last year of law school, when a white man thought it was not right for me to be there with three white women. As I confronted the situation, I weighed the fact that I have a black belt in Taekwondo agamst the fact that a young Chinese American man had been killed three years before just tlirty miles away in another case of mistaken racial identity. One of the assailants had commented, 'I don't like you because you're Vietnamese. Our brothers went over to Vietnam, and they never came back."374 I thought about the handgun that struck Jim Ming Hai Loo in the back of his head, causing him to fall on a broken beer bottle that pierced his eye and forced a bone fraginent into his brain. ${ }^{375}$ I realized then that knowing self-defense does little good in a country where guns are so readily available.

Incidents such as these make me realize that no level of privilege can

372. Id. Incidents such as this one call into question the reliability of eyewitness identification of Asian-American suspects by non-Asian Americans. This issue was central to a controversy involving the San Jose Police Department in 1991, which used an "Asian mug book containing 436 photographs of Asian men between the ages of 18 to 25, most of them Vietnamese" and another "mug book containing 50 photographs of mostly Samoan men." Donna Yamashiro, "Mug Book" Issue Resolved, The Alliance (Asian Law Alliance, San Jose, CA), Fall 1991, at 5. At least 10\% of the men in the Vietnamese mug book had never been arrested and an undisclosed number had never been charged or convicted. One consequence of the mug books involved a young Vietnamese man, mistakenly identified through the mug book, who was held in jail for more than three months, spent more than $\$ 20,000$ in attorney fees, and lost business contracts before being acquitted by a jury. His picture had been placed in the book two years before, "merely because the SJPD [San Jose Police Department] suspected him of involvement with a different crime, although the SJPD did not even arrest or charge him in the first event." Id. Asian Americans are subject to the "they all look alike syndrome" because of the inability of many non-Asian Americans to distinguish among individual Asian Americans. See Lawrence, supra note 75, at $341 \mathrm{n} .100$; see also Sheri L. Johnson, Cross-Racial Identification Errors in Criminal Cases, 69 CORNELL L. REv. 934, 940 (1984) (reporting that studies generally show that both whites and blacks have more difficulty identifying Asian faces than white and black faces).

373. See supra text accompanying note 32 .

374. CIVIL Rights REPORT, supra note 7, at 26 (citing Seth Effron, Racial Slaying Prompts Fear, Anger in Raleigh, GreensBoro News \& Rec., Sept. 24, 1989). Jim Ming Hai Loo was the victim of a racially charged murder that occurred outside a pool hall in Raleigh, North Carolina, in 1989. Id.

375. Id. 
protect me, that no level of privilege will protect my children from hateful schoolyard name-calling ${ }^{376}$ or the bullets of an insane, Asian-hating gunman. ${ }^{377}$

I can try to insulate or distance myself from this by calling them isolated incidents. But because anti-Asian violence and sentiments exist and to the extent that non-Asians have difficulty differentiating among Asians, any efforts to rationalize away racism only create rational lies.

Upon this realization, I begin to understand that I ain not so different from that Filipmo inan who did not get a job because of his accent or those Asian Americans who do not vote because they cannot read the English-only ballots. I begin to understand that all oppression is connected and that its roots lie in the past. This oppression is not a new phenomenon, but the tired replay of that same old deadly tune that left thirty-one Chinese miners dead and mutilated in the 1887 Snake River (Oregon) Massacre. ${ }^{378}$

Today, the massacres of Asian Americans are not always physical. Many of today's massacres are of the spirit because that is what racism does: it murders the spirit. ${ }^{379}$

Thus, the time for saying "not me, not me" is over. In demanding justice, we can ask as Hillel said in the Avoth, "[I]f not now, when?"380 Asian American legal scholars can add, "If not us, who?"

\section{IV}

\section{TOWARD AN ASIAN AMERICAN LEgal SCHOLARSHIP}

The time has coine to announce once again an Asian Ainerican Moment. With it comes an Asian American Legal Scholarship, which includes writing law review articles, writing briefs in the civil rights context, and teaching law school courses. Through these inedia, we have the opportunity to speak our oppression into existence. By doing so, we then

376. Id. at 88-99 (discussing racial tensions and hostilities in public schools).

377. This reference is to the 1989 "Stockton Schoolyard Massacre" in which Patrick Edward Purdy fired an AK47 assault rifle in the schoolyard at Cleveland Elementary School in Stockton, California. Id. at 30. Five Indochinese children were killed and thirty others wounded. Sixty percent of the children at the school were Southeast Asian. Id. The national press hardly addressed the possibility that the killings were racially motivated. Id. The California Attorney General, John Van de Kamp, later issued a report stating: "It appears highly probable that Purdy deliberately chose Cleveland Elementary School as the location for his murderous assault in substantial part because it was heavily populated by Southeast Asian children. His frequent resentful comments about Southeast Asians indicate a particular animosity against them." Nelson Kempsky, Chief Deputy Attorney General, State of California, A Report to Attorney General John K. Van de Kamp on Patrick Edward Purdy and the Cleveland School Killings 12 (Oct. 1989), guoted in CiviL RIGHTS REPORT, supra note 7 , at 31 .

378. CIVIL RightS REPORT, supra note 7 , at 6.

379. Cf. Williams, supra note 114 , at $129,139-45$ (discussing how racism is a crime as painful, costly, and psychically devastating as robbery or assault).

380. Pirkei Avoth 1:14, MishnaH (quoting Rabbi Hillel). 
have an opportunity to erase this oppression. ${ }^{381}$

A diversity of views exists within Asian American Legal Scholarship. This diversity is inevitable, and it is indeed desirable, because diversity, a term not synonymous with divisiveness, serves as a source of strength. This diversity can be seen in the different responses of Asian Americans to oppression. Although these responses inay be in conflict, and soinetimes may even become hostile, the very existence of a discussion moves Asian American Legal Scholarship forward.

I view responses to oppression as falling withm three stages: denial of difference, affirmation of difference, and liberation from difference. ${ }^{382}$ By stages, I do not necessarily imply a historical order or progression. ${ }^{383}$ I set the stages out im this manner to provide a useful way to think about legal scholarship, ${ }^{384}$ and to avoid, I hope, soine of the divisiveness present in other groups. ${ }^{385}$ These stages may be schematized in the following

381. Cf. Johnson, supra note 123 , at 323 (noting that "[difference] must be represented in order to be erased").

382. My three stages follow closely the three stages used by Professor Patricia Cain to map out feminist legal scholarship. Patricia A. Cain, Feminist Jurisprudence: Grounding the Theories, 4 BERKELEY WOMEN'S L.J. 191, 198-20S (1989-90) (developing stages described by Clare Daiton, Where We Stand: Observations on the Situation of Feminist Legal Thought, 3 BERKELEX WOMEN's L.J. 1 (1987-88)). Cain's stage one is characterized by a focus on formal equality; stage two by cultural feminism and radical feminism; and stage three, by postmodern feminism. In setting out these stages, I draw comparisons between critical race theory and critical feminist theory. For a similar comparison, see Alex M. Johnson, Jr., The New Voice of Color, 100 YALE L.J. 2007 (1991). I do not use his categorizations, though; Johnson relies on the work of Cass Sunstein who identified three principal approaches in critical feminist theory: "difference," "different voice," and "dominance." See Cass R. Sunstein, Feminism and Legal Theory, 101 HARv. L. REv. 826, 827 (1988) (reviewing Catharine A. MacKinnon, Feminism UnModified (1987).

The "difference" approach corresponds to what other theorists have called "liberal feminism," and it relies on a denial of difference. This corresponds to Professor Cain's Stage One. The "different voice" and "dominance" approaches correspond to cultural feminism and radical feminism in stage two. When Professor Sunstein wrote his review, he did not take into account postmodern feminism, probably because it was not one of the principal approaches; thus he does not have something that corresponds to Professor Cain's stage three. Since that time, postmodern feminist theory has emerged as an important player in critical feminist theory. See, e.g., FEMINiSM/ Postmodernism, supra note 134; Cain, supra; Drncilla Cornell, The Doubly-Prized World: Myth, Allegory and the Feminine, 75 CORNELL L. REv. 644 (1990) (explaining the social construction of femininity and its relationship to sexual difference).

Critical race theory should acknowledge and develop its own stage three. I, of course, only begin to do this in the more limited context of Asian American Legal Scholarship.

383. All three stages exist simultaneously, although the balance among them may vary. Some theorists think of them as stages that one progresses through. Indeed, there seems to be a historical progression to feminist theory. See, e.g., Cain, supra note 382, at 198-205. Historical progression, though, should not be mistaken with logical precedence.

384. Further work may reveal more stages or may result in different delineations. As Professor Angela Harris said in a different context, "Accordingly, I invite the critique and subversion of my own generalizations." Harris, supra note 13, at 585. I, too, will subvert my own categories. See infra note 388 and accompanying text.

385. Setting out these stages at the "beginning" of Asian American Legal Scholarship, along with a way to understand these stages, may avoid some of the divisiveness that has developed in other movements. See Kennedy, supra note 5; Colloquy, supra note 128.

Professor Alex Johnson harmonizes the different perspectives within the so-called "Racial 
manner:

Stage One: Denial of difference-

Traditional Asian American Civil Rights Work; accepts underlying legal principles with formal equality as its goal.

\section{Stage Two: Affirmation of difference-}

Cultural Asian American Legal Scholarship; ${ }^{386}$ challenges underlying legal principles and legal institutions that inay not be valid for Asian Americans because of cultural differences.

Radical Asian American Legal Scholarship; ${ }^{387}$ challenges legal principles based on dominance theory.

Stage Three: Liberation from difference-

Post-structural Asian American Legal Scholarship; challenges limitations caused by categories but is pragmatic in its approach.

\section{A. Stage One: Denial}

The first stage is characterized by a denial of difference and, usually, faith in traditional civil rights work. This faith is premised on notions grounded in liberal political philosopliy. The methods employed may be race-neutral or race-conscious. ${ }^{388}$ Yick Wo v. Hopkins, ${ }^{389}$ which held

Critiques Debate." See Johnson, supra note 382. In the same fashion, those Asian American legal scholars with differing theoretical commitments and methodologies should understand that we all have the same goal in mind: "It is our differences that strengthen us in our quest to achieve this common objective. If we lose sight of this common objective and engage in vitriolic debate concerning which viewpoint is 'correct,' we will then let our differences divide us, and our shared objective will never be realized." Id. at 2063.

386. This is my label. I use it to indicate similarities in theme, not necessarily in method, with the work of cultural feminists. See, e.g., West, supra note 112. West criticizes liberalism and critical legal studies for ignoring what she calls "the central insight of feminist theory of the last decade... [which is] that women are 'essentially connected,' not 'essentially separate,' from the rest of human life, both materially ... and existentially, through the moral and practical life." Id. at 3 . In taking this stance, Professor West's work is vulnerable to the essentialism critique. See, e.g., Harris, supra note 13 .

387. This label, like Cultural Asian American Legal Scholarship, was chosen for its affinity with radical feminism. Radical Asian American Legal Scholarship focuses on racial dominance and power to critique the current political-legal system.

388. I include race-conscious methods here rather than under Stage Two, because, even though race-conscious methods acknowledge race, they abandon their remedial aspects once some semblance of equality is achieved. Another reason is that race-conscious measures often paint the subject as victim, a characterization antithetieal to the Stage Two's emphasis on empowerment. $C f$. Elizabeth M. Schneider, Describing and Changing: Women's Self-Defense Work and the Problem of Expert Testimony on Battering, 9 WOMEN'S RTS. L. REP. 195, 197 (1986) (“[C]ases involving expert testimony on battered woman syndrome resound with the very sex-stereotypes of female incapacity which women's self-defense work has sought to overcome."). I realize that by including raceconscious methods, I may have blurred the line between Stages One and Two, but this framework remains a useful way to talk about these issues while fulfilling my need to categorize. And "[e]ven a jurisprudence based on multiple consciousness must categorize; without categorization each individual is . . . isolated ... and there can be no moral responsibility or social change." Harris, supra note 13, at 586. I, too, categorize but not in an ahistorical or noneontextual manner.

389. 118 U.S. 356 (1886). 
that the Fourteenth Amendment's Equal Protection Clause applied to Chinese and other immigrants, ${ }^{390}$ represents an example of a successful race-neutral effort under Stage One. A consent decree that set forth goals and timetables for the San Francisco Pohice Department to hire persons bilimgual in Chinese is an example of a successful race-conscious effort under Stage One. ${ }^{391}$ Another successful race-conscious effort is the Voting Rights Language Assistance Act of $1992 .{ }^{392}$ As these victories indicate, legal scliolarship in Stage One focuses on formal equality and pursues remedial measures in order to obtain equal rights.

The denial of difference im Stage One is often accompanied by a preference for assimilation as a solution to discrimination. For example, one Japanese American newspaper in 1929 urged the Nisei-second generation Japanese Americans-to become "one liundred percent Americans" in order to avoid discrimination. ${ }^{393}$ Failure to assimilate fully, we are warned, leads to the imposition of certain penalties. ${ }^{394}$

Problems arise, though, when some people realize the contradictions of assimilation: "I wanted to be an American. ... I wondered why God had not made me an American. If I couldn't be an American, then what was I? A Japanese? No. But not an American either. My life background is American. . . [But] my looks made me Japanese."395 Such a realization may either lead someone to try even harder to be "American," 396 or to reject full assimilation and accept being different. Proponents of Stage Two start from this prentise. ${ }^{397}$

390. Id. at 369 (holding that the Equal Protection Clause of the Fourteenth Amendment applies to all persons within the United States regardless of race, color or nationality).

391. See supra note 110.

392. 42 U.S.C. \$ 1973aa-1a (1992); see supra Part III. I am tempted to include this as a successful Stage Two effort, but the tenor of the House Report on the Act suggests that Congress viewed it as a temporary measure which will not be renewed once (if?) voter registration figures for Asian Americans begin to approach those of other groups. See H.R. REP. No. 655, 102d Cong., $2 d$. Sess. (1992), reprinted in 1992 U.S.C.C.A.N. 766 (discussing how the Act has been repeatedly "renewed" for temporary periods, with it due to expire again in the year 2007).

393. TAKAKl, supra note 1, at 222 (quoting Japanese American Courier, Aug. 31, 1929, Jan. 1, 1928). Along the same line, a 1939 editorial in the San Francisco Japanese American News (Nichi Bei) said that the time had come to "burn a few of our bridges behind us." Id. at 224.

394. See, e.g., Calmore, supra note 15, at 2220 (discussing how Black "styles of interaction" are deemed "inappropriate to the business world"); Matsuda, supra note 172, at 1333-49 (retelling the experiences of a number of employees who were penalized for not losing their "foreign" accents).

395. TAKAKI, supra note 1, at 225 (quoting Aiji Tashiro, The Rising Son of the Rising Sun, NEW OUTLOOK, Sept. 1934, at 37) (second alteration in original).

396. Thus, Stage Two does not always follow from this realization because some people, even after recognizing their own predicament, try even harder to "be" white. See, e.g., JANICE MIRIKITANI, Recipe, in SHEDDING SILENCE 20 (1987) (describing through poetry how someone might try to change "slant" eyes into round eyes with scissors, scotch tape, and eyeliner.)

397. I realize that I am implying some sort of personal forward progression or advancement for individuals, perhaps because I myself progressed through the stages in this order. But I choose to retain the bias rather than hide it in a cloak of objectivity. My purpose is to show that these three stages can all exist simultaneously within Asian American Legal Scholarship. 


\section{B. Stage Two: Affirmation}

Stage Two recognizes that formal equahity cannot give us what it promises; $; 98$ thus, rather than deny difference, Stage Two accepts and affirms it. In this stage, the disempowered group takes and reconstitutes the term "Asian American." 399 The oppressive label becomes a positive identity, a tool for empowerment. As such, a facet of Stage Two is its anti-assimilationist attitude. ${ }^{400}$ Assimilation is seen as undesirable because it "resembles the attempt to run away from ourselves, with success coming only through the negation of self, history, culture, and community." 401 In opposition to assimilation is plurahistic integration, ${ }^{402}$ which is based on an appreciation of American society's culturally plurahistic nature. ${ }^{403}$

398. Cf. Gotanda, supra note 115, at 2-3 ("A color-blind interpretation of the Constitution legitimates, and thereby maintains, the social, economic, and political advantages that whites hold over other Americans.").

399. For example, we adopt "Asian American" in place of "Oriental," even though "Asian American" is a term "crcated in the West from the need to make racial categorizations in a racially divided or, at least, a racially diverse society." KIM, supra note 7 , at xii.

400. By assimilation, I mean the following: "'identificational assimilation' which is the 'development of [a] sense of peoplehood based exclusively on [the] host society ... [and] 'cultural or behavioral assimilation,' a process by which ethnic group members increasingly adopt the cultural characteristics and patterns of the host society." Calmore, supra note 15, at 2220 (quoting MiLTON Gordon, Assimilation in American life: The Role of Race, Religion and National ORIGINS 71 (1964)) (some alteration in original).

401. Id. at 2226.

402. The true opposite of assimilation is of course separatism. A full discussion of separatism and Asian American Legal Scholarship is beyond the scope of this Article.

403. Integration is a problematic term, and whether you support integration or not depends on how you define it. The ambiguous nature of integration is evident in Steven Biko's response to the question of integration:

If by integration you understand a breakthrough into white society by blacks, an assimilation and acceptance of blacks into an already established set of norms and code of behaviour set up by and maintained by whites, then YES I am against it. . . .

If on the other hand by integration you mcan there shall be free participation by all members of a society, catering for the full expression of the self in a freely changing society as determined by the will of the people, then I am with you. For one cannot escape the fact that the culture shared by the majority group in any given society must ultimately determine the broad direction taken by the joint culture of that society. This need not cramp the style of those who feel differently ....

STEve BIKo, Black Souls in White Skins?, in I WRITE What I LIKE 19, 24 (Aelred Stubbs ed., 1978). By using "pluralistic integration," I hope to capture the view espoused by W.E.B. Du Bois, who emphasized the complementary relationships of the racial groups of humankind. See Appiah, supra note 17, at 25; cf. Carol Gilligan, Moral Orientation and Moral Development, in WOMEN AND MORAL THEORY, supra note 211, at 19, 22-23, 31-32 (arguing that women's ethic of care and men's ethic of justice cannot be integrated because one can see from only one perspective at a time, although it is possible to switch between them).

Many people would like to think of the United States as a melting pot, that diverse groups enter the United States and evolve into unhyphenated Americans. But racial minorities understand this to be a lie. Justice Thurgood Marshall commented, "The dream of America as the great melting pot has not been realized for the Negro; because of his skin color he never even made it into the pot." Regents of the Univ. of Cal. v. Bakke, 438 U.S. 265, 400-01 (1978) (Marshall, J. concurring in the judgment). Likewise, I know that my future children, and their children, will never be Americans. They will always be Asian Americans. I can bemoan their fate that they will never be plain 
The characteristics of Stage Two are evident in Cultural Asian American Legal Scholarship, which emphasizes cultural differences as a method to criticize legal principles and legal institutions that fail to take into account these differences. An example of work $m$ this area is Questioning the Cultural and Gender-Based Assumptions of the Adversary System: Voices of Asian American Law Students, ${ }^{404}$ written by Carolyn Jin-Myung Oh. In her article, Oh examines the cultural backgrounds of some Asian American law students and their perceptions of the adversary system. She contrasts Western notions of individuality and self-sufficiency with the greater emphasis on family in most Asian and Pacific American cultures. ${ }^{405}$ She hypothesizes about the effects of Confucian principles "which emphasize specific roles and proper harmonious relationships among people in family and society. Because harmonious interpersonal relationships are so highly valued, direct confrontation is avoided whenever possible. Being indirect or talking around the point is a significant part of the communication style of Asian groups." ${ }^{\text {"406 }}$ While the scope of her article is limited to responses of Asian American and Caucasian law students to the potentially alienating legal system and their perceived roles within it, ${ }^{407}$ her focus on cultural explanations is a good example of the Cultural Asian American Legal Scholarship einbodied in Stage Two. ${ }^{408}$

Americans, or I can celebrate that they will be Asian Americans. The choice seems easy, but in order to do the latter, I must give them back their heritage. Some people have moved away from the "melting pot" image to a "salad bowl" in which minority cultures maintain their distinctiveness in a way that makes them co-equal with other cultures. See, e.g., Frank M. Lowrey, IV, Comment, Through the Looking Glass: Linguistic Separatism and National Unity, 41 EMORY L.J. 223, 306 (1992) (discussing the efforts of the Hispanic political establishment to preserve Hispanic culture from assimilation). I have also heard the term "mosaic" to represent this pluralistic society. I prefer "collage" as more descriptive of our society.

404. 7 BERKELEY WOMEN's L.J. 125 (1992).

405. Id. at 126-27.

406. Id. at 127 (footnote omitted).

407. Oh, however, found gender to be a better predictor of perceptions of the adversary system, although she admittedly had only a small sample of students, all from Boalt Hall School of Law. In the test group, there were 12 Asian Americans (half men, half women, of differing levels of cultural assimilation), and in the control group, there were 10 Caucasians (half men, half women). Id. at 128-29. She did not take class differences into account.

408. The differing communication styles of Asian Americans may also affect such things as their credibility as litigants and witnesses. Further, perhaps the courts should recognize certain cultural defenses for Asian American parties. See, e.g., Anh T. Lam, Culture as a Defense: Preventing Judicial Bias Against Asians and Pacific Islanders, 1 UCLA AsIAN AM. PAC. IsLANDs L.J. 49, 53-57 (1993) (arguing that the objective reasonable man standard is inappropriate in certain cases and that traditional defenses and prosecutorial discretion may not provide sufficient safeguards for some minority defendants).

We must take care, however, not to allow cultural defenses to further the oppression of women. For example, following the Clarence Thomas confirmation hearings, Professor Orlando Patterson argued that "even if testimony about Thomas's gross pornography-laden harassment was actually true, Thomas was justified in lying about it given that such behavior was recognizable (and apparently acceptable) to Black women as simply a style of 'down home courting.' Kimberlé Crenshaw, Race, Gender, and Sexual Harassment, 65 S. CAL. L. Rev. 1467, 1471 (1992). Professor 
We can use differences between Asian cultures and Western cultures to question the assumptions of Stage One's hiberal political theory, which celebrates the notion of an individuated autonomous self. As mentioned earhier, many Asian philosophies have at their center the concept of noself. ${ }^{409}$ Without a metaphysical "self" as a locus for rights, liberalisin and rights talk lack coherence. Nevertheless, Stage Two of Asian American Legal Scholarship recognizes that formal equality cannot be denied to Asian Americans. Thus, Stage Two inay also employ the raceneutral and race-conscious methods of Stage One without sharing its commitinent to hiberal political philosophy.

Cultural Asian American Legal Scholarship must avoid the pitfall of essentialisn present in cultural feminist theory. ${ }^{410}$ We must not generalize the cultural differences of certain Asian American groups or individuals in a way that excludes those who do not fit those characteristics. ${ }^{411}$ Thus, for example, when authors write about Confucian principles, they should be careful to note that for many Asian American groups, such as Filipinos, South Asians and many Southeast Asians, Confucian principles may not be a significant part of their culture.

In addition to the essentialist critique, there is a further danger in accepting difference, because difference, once recognized, can serve as the basis for discrimination. This is, after all, exactly what discrimination is-differential treatment based on difference. Radical Asian American Legal Scholarship operates at this juncture by focusing on differences in power, particularly on how inequality in power has constructed and legitimated racial subordination. Its focus thus contrasts with traditional Asian American civil rights work, which treats difference as an illusion or something to get beyond, ${ }^{412}$ and with Cultural Asian American Legal

Crenshaw goes on to point out that Patterson's "cultural defense effectively deflects criticisms of sexist attitudes and practices that subordinate Black women and other women of color in our communities." Id. at 1472 .

409. See, e.g., RAHULA, supra note 113; see also UNGER, supra note 113, at 155 ("Without the social productions of culture [a person] cannot develop his characteristic human capacities. Without the recognition of his personality by others, he cannot arrive at a definition of his own identity.").

410. See, e.g., West, supra note 112 , at 3 (positing that all women are connected by four experiences: "the experience of pregnancy itself; the invasive and 'connecting' experience of heterosexual penetration, which may lead to pregnancy; the monthly experience of menstruation, which represents the potential for pregnancy; and the post-pregnancy experienee of breastfeeding."). West has come under criticism, however, for ignoring lesbian experiences in formulating her thesis. See Cain, supra note 382, at 201.

411. Cf. SPELMAN, supra note 185. For those who know exclusion, to turn around and exclude others is a double sin. Cultural Asian American Legal Scholarship must not attain its ends at the expense of the voices of women and gays and lesbians. See Merle Woo, Letter to Ma, in TH1s BRIDGE CALIED MY BACK, supra note 80, at 140, 145 ("Some Asian men don't seem to understand that by supporting Third World women and fighting sexism, they are helping themselves as wcll.").

Our Scholarship must also expose the "model minority" myth, which overlooks the plight of some Asian American groups while seeking to discredit other minority groups. See supra notes 73 105 and accompanying text.

412. Cf. MacKinnon, supra note 196, at 183 ("Where liberal feminism sees sexism primarily as 
Scholarship, which celebrates difference. ${ }^{413}$

\section{Stage Three: Liberation}

We see, then, that though there is power in affirming the category Asian American, the category is also limiting, especially because it reinains defined in terms of the dominant group. ${ }^{414}$ As long as our identity is defined oppositionally or in contradistinction to others, we are still enslaved to a degree. That the term "Asian American" can be an oppressive categorization is the starting point of the third branch of Asian American Legal Scholarship-post-structuralisin-which deconstructs the category "Asian American," einancipating us from its limits. Only when we are free of it can we be free to give ourselves our own identity. ${ }^{415}$ Only in this way can we be free to embrace our identity rather than having our identity thrust upon us froin the outside. ${ }^{416}$

The question becoines whether Asian American Legal Scholarship can survive this post-structural deconstruction of the category "Asian American." 417 If a full post-structural critique deconstructs all categories, including race, then once the category "Asian American" is deconstructed, so the question goes, how can it any longer serve as a useful category? This critique misunderstands deconstruction. Part of the problein lies in the word "deconstruction" which inplies a breaking down or breaking apart. ${ }^{418}$ Deconstruction does no such thing. It reveals things to be historically situated and socially constructed, but this realization in no way changes the current construction of the category except to reinove any foundational claims. ${ }^{419}$ Deconstruction sinply

an illusion or myth to be dispelled, an inaccuracy to be corrected, true feminism sees the male point of view as fundamental to the male power to create the world in its own image, the image of its desires, not just as its delusory end product.").

413. See supra notes $404-08$ and accompanying text.

414. See generally supra note 7.

415. " "AAn] oppressed group must at once shatter the self-reflecting world which encircles it and, at the same time, project its own image onto history. In order to discover its own identity as distinct from that of the oppressor, it has to become visible to itself.' " MACKINNON, supra note 165, at 84 (quoting Sheila RowbothaM, Woman's ConsciousNess, MAN's World 27 (1973)). I realize that this is a modernist hope. There is no way that we can be "free" in the sense that I describe because that state exists only in an ahistorical, acontextual situation. Such a situation is not possible because everything, everyone is situated somehow in this world, and this is not a bad thing. See FISH, supra note 200, at 16 (arguing that "those feminists who rely in their arguments on a distinction betwecn male and female epistemologies are wrong").

416. This desire to be free of the category "Asian American" should not be confused with a desire to reject our cultural heritage. If anything, it is the opposite, because so long as our identity is oppositionally defined or taken in reactionary manner, we will remain oppressed.

417. Cf. Patterson, supra note 175, at 255 (posing the question, "Can feminism survive the postmodern critique of reason?").

418. For this reason, Drucilla Cornell uses "the philosophy of the limit" to describe "deconstruction." Drucilla Cornell, The Philosophy of the Limir 1 (1992).

419. Fish often talks about the fact that post-structuralism has "no consequences." E.g., FISH, supra note 200 , at 315-55. 
reveals the potential for change; a category could be constructed differently in the future, or perhaps our present could be reconstructed differently by revising or reinterpreting our past. ${ }^{420}$ To reiterate, in no way does deconstructing the category "Asian American" change the fact that I an an Asian American. My context has constructed me as Asian American.

This understanding of contextual situatedness enables Post-structural Asian American Legal Scholarship to use multiple consciousness as a inethod to understand and participate in Stages One, Two, and Three without inconsistency. ${ }^{421}$ It is able to do this because it understands law as a contextual practice that has certain rules. Even while it criticizes and tries to undermine those rules, it can engage in civil rights struggles because it understands that removal of oppression is beneficial, even if it inust come in stages. Mari Matsuda's article, Voices of America: Accent, Antidiscrimination Law, and a Jurisprudence for the Last Reconstruction, ${ }^{422}$ is an example of inultiple consciousness at work. She says at the end of her article, "I have written to persuade readers of good will to adopt legal rules and ethical positions that promote linguistic plurahism. I have used existing legal doctrine, traditional liberal theory, and new critical theories in this effort." ${ }^{\prime 23}$ She recognizes the inherent contradictions, the internal inconsistencies of doing all three, yet she is able to do it because an Asian American Legal Scholarship has a pragmatic face. It has a multiple consciousness that can assume various guises. It assumes these guises with a final goal in mind: liberation.

Tremendous diversity exists within the category "Asian Ainerican." And tremendous diversity exists among the disempowered. We must remember, though, that it is only through solidarity that we will one day be free to express our diversity.

\section{CODA}

As I look back on what I have written, I realize that I have done the easy part. The real work remains to be done. I think about my mother who is an artist. She begins her work by putting together a fraine. She stretches the canvas, tightly so that the surface will be smooth. Then her work begins in earnest. She looks at the broad expanse of canvas. She looks at that empty space. She looks. And then, from somewhere within, she calls up her vision and fills the void. I think of the framework

420. This is why legal historiographical study will be important for Asian Americans to reconstruct their past and to take their proper place in the history of this country and its legal institutions.

421. See Calmore, supra note 15 , at $2164-65$ ("[C]ritical race theory is necessarily eclectic, incorporating what appears to be helpful from various disciplines, doctrines, styles, and methods."); Matsuda, supra note 13.

422. 100 YALE L.J. 1329 (1991).

423. Id. at 1403 . 
that I have constructed. I think of that broad expanse of canvas that waits to be filled. I wonder how my mother does it. And I wonder if the legal academy is ready for this Asian American Moment, whether it is ready for an Asian American Legal Scholarship. Then I remember Mari Matsuda's words, spoken in a different context but equally applicable here:

[W] cannot listen to those who say, "it's not yet tine." We know it's time, our time, and we will make it so. ${ }^{424}$ And so, let us raise our voices. Let us make it so. 
